\title{
Electrophysiological characterization of insulin secreting $\beta$-cells in pancreatic tissue slices
}

\section{PhD Thesis}

in partial fulfilment of the requirements for the degree Doctor of Philosophy $(\mathrm{PhD})$ in the Neuroscience Program at the Georg August University Göttingen,

Faculty of Biology

\author{
Submitted by \\ Stephan Speier \\ born in \\ Köln, Germany
}

Göttingen, 2004 
Here I declare that I have written the PhD thesis:

'Electrophysiological characterization of insulin secreting $\beta$-cells in pancreatic tissue slices'

independently and with no other sources and aids than quoted.

Göttingen, September, 2004

Stephan Speier 


\section{Dedicated to Mum and Dad. Thank you for your never ending support.}

\section{ACKNOWLEDGEMENTS}

I would like to thank all colleagues and friends that helped and encouraged me during my years as a $\mathrm{PhD}$ student. Some of those people deserve special mentioning:

My supervisor Dr. Marjan Rupnik, for leading me into the complex field of electrophysiology, for his enthusiasm and for giving me the opportunity to gain insight into the Diabetes research community

Shi-Bing, for many valuable scientific discussions about channel physiology Tobias and Robert for fruitful interlocutions after work

My favorite technician Marion for all her cooperation and stories

Heiko, Alex and all the other people that made life in the lab so enjoyable

And of course Ala for her love and patience! 


\section{CONTENTS}

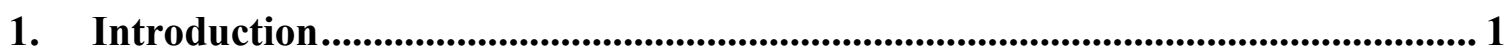

1.1. Physiology and pathophysiology of blood glucose regulation ....................... 1

1.2. Structures involved in insulin secretion ..................................................... 3

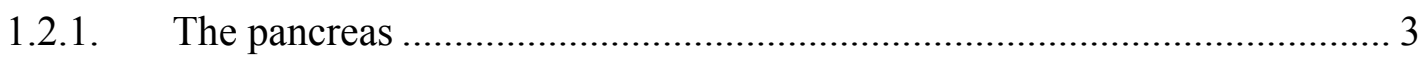

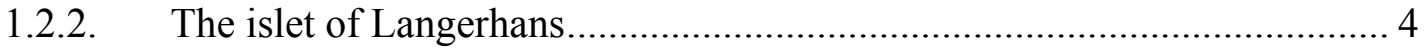

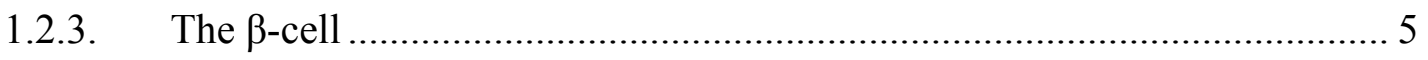

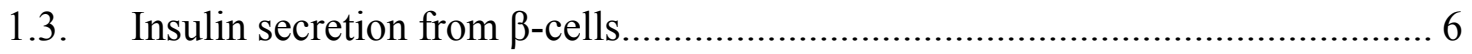

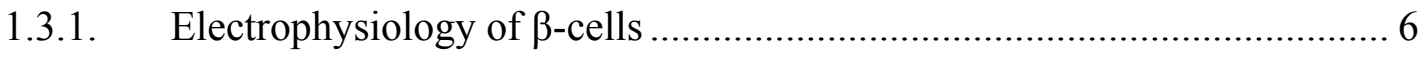

1.3.2. Stimulus-secretion coupling in $\beta$-cells............................................ 9

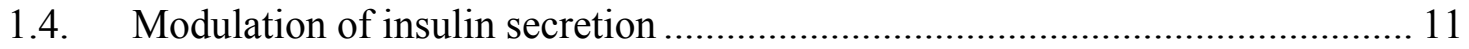

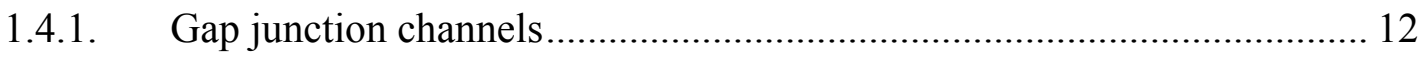

1.4.2. Influence of paracrine hormone secretion.......................................... 13

1.4.3. Neuronal regulation of insulin release .............................................. 14

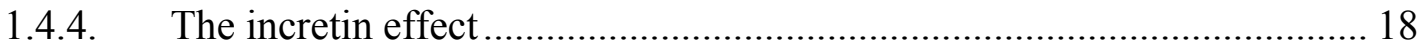

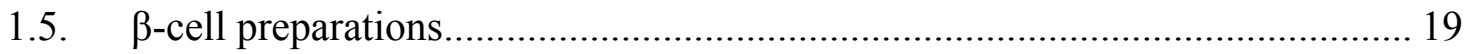

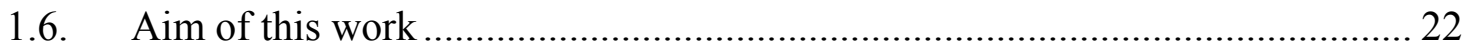

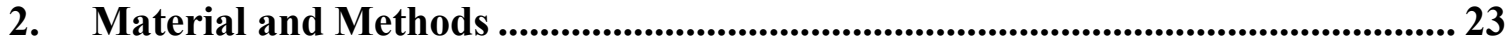

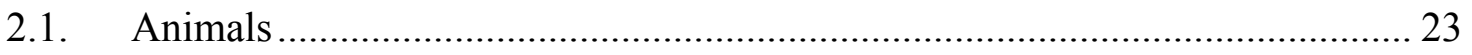

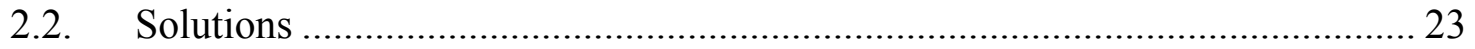

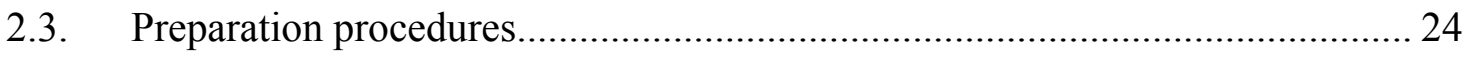

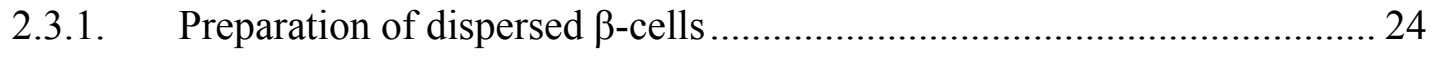


2.3.2. Preparation of pancreatic tissue slices ................................................ 25

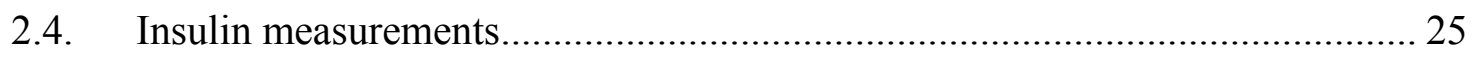

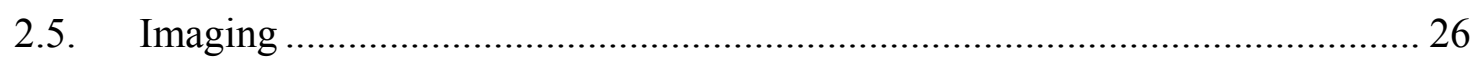

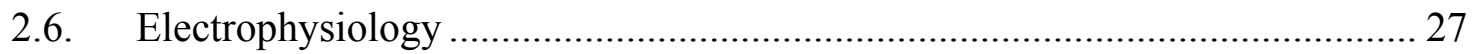

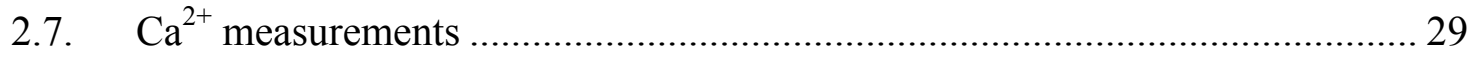

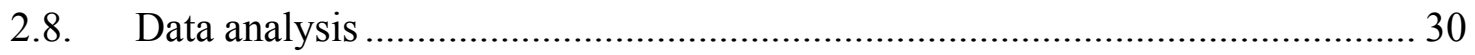

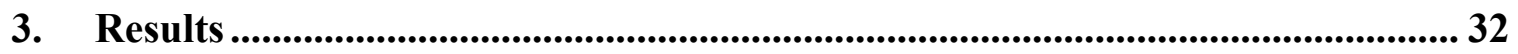

3.1. Features of mouse pancreatic tissue slices............................................ 32

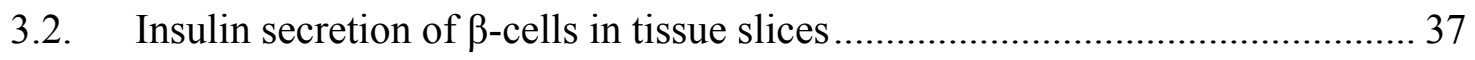

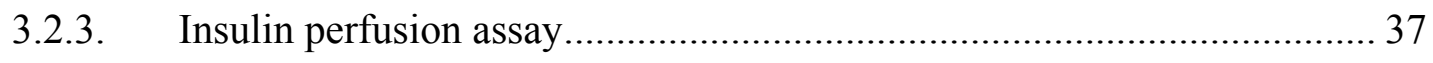

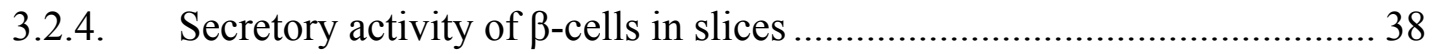

3.3. Electrical activity of $\beta$-cells in the pancreatic tissue slice ............................ 39

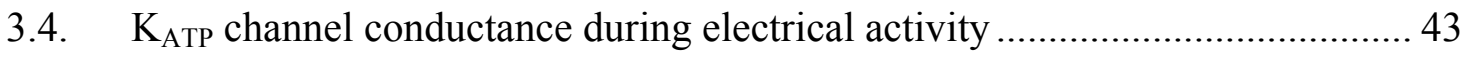

3.5. $\mathrm{K}_{\mathrm{ATP}}$ channel properties in $\beta$-cells in tissue slices and dispersed $\beta$-cells......... 45

3.6. Gap junction channel contribution to electrical activity ............................... 53

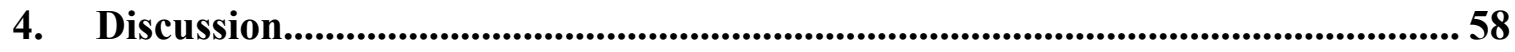

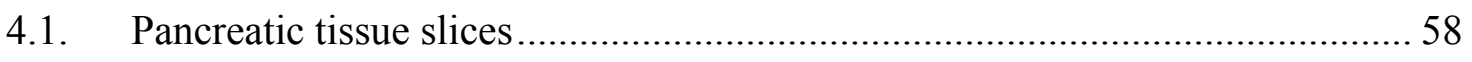

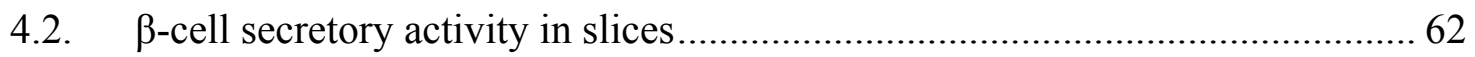

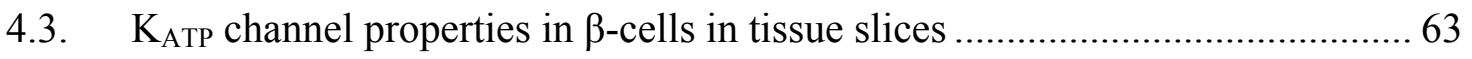

4.4. Contribution of gap junctions to electrical activity of $\beta$-cells in tissue slices .. 67

4.5. Performing the patch-clamp technique in tissue slices ............................. 70

4.6. Perspectives for the pancreatic tissue slice preparation .............................. 72

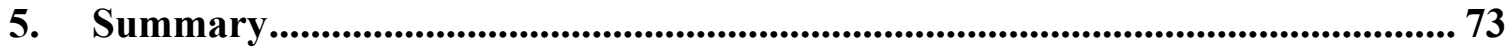


6. References ...................................................................................................................... 75

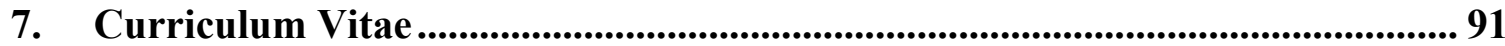

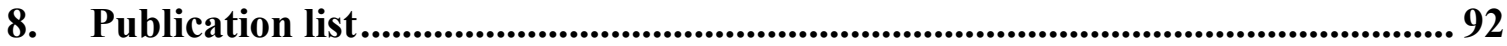




\section{Introduction}

\subsection{Physiology and pathophysiology of blood glucose regulation}

Glucose, a simple monosaccharide sugar, acts as an energy supplying molecule in animals and plants. In humans glucose serves as the main energy source for almost all types of tissue, with the CNS being exclusively dependent on glucose. The cellular respiration process brakes down glucose, releasing energy which is trapped in the form of adenosine triphosphate (ATP). ATP is then used as an instantaneously available form of energy for all kinds of cellular reactions. The body obtains glucose directly from the diet or from amino acids and lactate via gluconeogenesis. Glucose gained from these two primary sources either remains soluble in the body fluids or is stored in the liver in a polymeric form as glycogen.

Human blood glucose levels are normally maintained within a narrow range between 70 and $110 \mathrm{mg} / \mathrm{dl}(\sim 4-6 \mathrm{mM})$, called normoglycemia. Blood glucose concentrations below $70 \mathrm{mg} / \mathrm{dl}$ are termed hypoglycemia. After a meal blood glucose levels can increase above $110 \mathrm{mg} / \mathrm{dl}$, but concentrations exceeding $180 \mathrm{mg} / \mathrm{dl}$ are considered as hyperglycemia. Normoglycemia is balanced by glucose entry to the bloodstream, mainly from the liver, and glucose uptake by peripheral tissues. Many factors account for this homeostatic process, but hormone regulation is the most important. Two groups of antagonistic hormones affect blood glucose levels. Hyperglycemic hormones like glucagon, growth hormone and catecholamines increase hepatic glucose production by stimulating gluconeogenesis and glycogenolysis which leads to elevated blood glucose levels. In 
contrast the hypoglycemic hormone, insulin, decreases blood glucose by suppressing hepatic glucose production and stimulating glucose uptake, mainly into skeletal muscle. Because insulin is the only hypoglycemic hormone its proper release and function is of major importance. Diabetes mellitus is a group of metabolic disorders characterized by increased blood glucose concentrations resulting from defects in insulin secretion, insulin action or both. Chronic diabetic hyperglycemia is accompanied by long-term damage of various tissues. Especially eyes, kidneys, nerves, heart and blood vessels suffer from dysfunction and failure. Diabetes is diagnosed by measuring fasting glucose levels $\geq 125$ $\mathrm{mg} / \mathrm{dl}(7.0 \mathrm{mM})$ or a plasma glucose $\geq 200 \mathrm{mg} / \mathrm{dl}(11 \mathrm{mM})$ two hours after a $75 \mathrm{~g}$ oral glucose tolerance test. Diabetes is classified into type 1 diabetes, type 2 diabetes, other specific types of diabetes and gestational diabetes. Type 1 diabetes is caused by a total lack of insulin due to destruction of the insulin secreting $\beta$-cells. Its treatment is therefore based on the substitution of insulin. Type 1 diabetes represents $5-15 \%$ of diabetes mellitus cases and it is the most frequent cause of chronic disease in young people. The peak incidence of Type 1 diabetes is between 10 and 14 years of age. Type 2 diabetes is the most common form of diabetes $(85-95 \%)$ and affects $5-7 \%$ of the world's population, especially people of 60 years of age and older. Type 2 diabetes is a heterogeneous syndrome with various combinations of insulin resistance and $\beta$-cell failure. These defects are caused by the interaction of several environmental factors and multiple diabetogenic genes. Environmental risk factors for type 2 diabetes include obesity and physical inactivity, as well as malnutrition in utero and during infancy.

Diabetes mellitus is a severe and costly disease which is becoming increasingly common. In the year 2000 at least 177 million people worldwide suffered from diabetes and this 
number is likely to be more than double in 2030. Every year around 4 million deaths are attributable to complications of diabetes. Overall the direct health care costs of diabetes range from 2.5 to $15 \%$ of the annual health care budget of a country, depending on the local diabetes prevalence.

\subsection{Structures involved in insulin secretion}

\subsubsection{The pancreas}

The pancreas is a retroperitoneal organ located posterior to the stomach on the posterior abdominal wall. In humans the pancreas is a small elongated well-defined organ of compact structure. In contrast, the pancreas in rodents is a diffuse organ distributed between different parts of the intestines and the spleen, not easily distinguishable from surrounding adipose tissue. The bulk of the pancreas is composed of exocrine cells, containing digestive enzymes (mainly trypsin, chemotrypsin, pancreatic lipase and amylase) that are secreted into acinus. The pancreas is the main source of enzymes digesting fats and proteins. Furthermore pancreas secretion contains bicarbonate ions to neutralize the acidic chyme that the stomach churns out. Embedded throughout the exocrine tissue are clusters of cells called the islets of Langerhans, which are the endocrine cells of the pancreas and secrete hormones. All pancreatic cell types are derived embryologically from endoderm outgrowths on the fetal gut. 


\subsubsection{The islet of Langerhans}

The normal adult human pancreas contains about 1 million islets, representing the endocrine tissue of the gland and making up $2-3 \%$ of the gland's mass. Islets of Langerhans are composed of several different cell types. The main cell types are $\beta$-cells (producing insulin), $\alpha$-cells (glucagon), $\delta$-cells (somatostatin) and PP-cells (pancreatic polypeptide), occurring in the ratio $68: 20: 10: 2 \%$ (Rahier, 1988). The core of each islet contains primarily $\beta$-cells surrounded by a mantle made up of all four cell types.

Islet cells may interact with each other through direct contact and through systemic or paracrine effects. The highly specialized pattern of blood flow through the islet of Langerhans probably controls local and systemic interactions. Although the islets constitute only a minor part of the total pancreas mass, they receive about $20 \%$ of total pancreatic blood flow (Lifson et al., 1985), and this portion is further increased when glucose levels are high (Jansson and Hellerstrom, 1983). Blood enters the islet through an arteriole which ends in the $\beta$-cell-rich core. From there the blood flows centrifugally to the peripherally located venules. Thus, insulin is carried to the $\alpha$ - and $\delta$-cells able to influence their activity (Stagner et al., 1988; Stagner and Samols, 1992; Stagner et al., 1992). On the other hand, this indicates that blood-borne glucagon and somatostatin must pass through the systemic circulation before acting on $\beta$-cells. However, this only describes interactions that are mediated through the local islet vasculature and does not characterize the possible paracrine interactions via interstitial compartments of the islet. 


\subsubsection{The $\beta$-cell}

As mentioned above, the $\beta$-cell is the most abundant cell type in the islet of Langerhans and solely builds up its core. $\beta$-cells are of major interest because they are the only origin for the hypoglycemic hormone insulin. Under experimental conditions $\beta$-cells can be discriminated morphologically by their ellipsoid shape from $\delta$-cells and by their bigger size from $\alpha$-cells. Furthermore, different electrophysiological properties also enable to distinguish $\beta$-cells from non $\beta$-cells (Gopel et al., 1999). The principal gene product of the $\beta$-cell is preproinsulin, which is cleaved by protease activity in the endoplasmatic reticulum to yield proinsulin. This is packed in vesicles and transported to the golgi apparatus. Here, and in the maturating secretory vesicles, proinsulin is converted to insulin by the proteolytic removal of the connecting (C) peptide (Steiner et al., 1972). The resulting insulin has a lower solubility and so it coprecipitates with zinc ions to form microcrystals within the secretory granule (Orci et al., 1986). Insulin and C peptide are stored together in the secretory granule and are ultimately released in equimolar amounts. Under normal conditions $95 \%$ of the hormone product is secreted as insulin and less than $5 \%$ as unconverted proinsulin (Bell et al., 1980). Synthesis of proinsulin is rapidly increased in response to elevated extracellular glucose concentrations. In contrast, glucose has no effect on the conversion of proinsulin to insulin (Ashcroft et al., 1978).

The main physiological determinant of insulin release in mammals is blood glucose concentration. Some insulin secretagogues (e.g. glucose and arginine) can initiate insulin secretion alone, while others (e.g. glucagon) only exert stimulatory effects in the presence of an initiator. 


\subsection{Insulin secretion from $\beta$-cells}

\subsubsection{Electrophysiology of $\beta$-cells}

For a long time muscle and nerve cells were believed to be the only group of specialized cells provided with electrical excitability. However, during the 1960s and 1970s it was observed that a number of endocrine cells share this capacity and that they use membrane potential changes to couple alterations in their environment to the hormone secretion rate (Dean and Matthews, 1968; Taraskevich and Douglas, 1977). Dean and Matthews provided in 1968 the first evidence for glucose-stimulated electrical activity in $\beta$-cells (Dean and Matthews, 1968). Since then the features of this activity have been elaborated in numerous studies and were the subject of several reviews (Henquin and Meissner, 1984; Ashcroft and Rorsman, 1989; Cook et al., 1991).

At substimulatory glucose concentrations $(<7 \mathrm{mM})$ or in the absence of glucose, the $\beta$ cell is electrically silent, with a negative membrane potential of about $-70 \mathrm{mV}$. Raising glucose to insulin-releasing concentrations induces a depolarization of the $\beta$-cell membrane. After reaching the threshold potential between -50 and $-40 \mathrm{mV}$ electrical activity is initiated. The $\beta$-cell electrical activity follows a characteristic pattern of slow oscillations in membrane potential, with superimposed action potentials on the depolarized plateau, followed by repolarized electrically silent intervals (Fig.1). These oscillations of active and silent phases are referred to as bursts. As the glucose concentration is raised further the duration of the active phase of the burst is increased and the repolarized interval between them decreases, until at glucose concentrations above $20 \mathrm{mM}$ the depolarized plateau is sustained and the action potentials appear continuous. 
Under physiological glucose elevations insulin release is pulsatile undergoing short and long oscillations and there is evidence that the integrity of these responses is necessary for maintenance of normal glucose homeostasis (Matthews, 1991). Bursting has been shown to be directly correlated with pulsatile insulin release (Barbosa et al., 1996), indicating the importance of the electrical activity pattern.

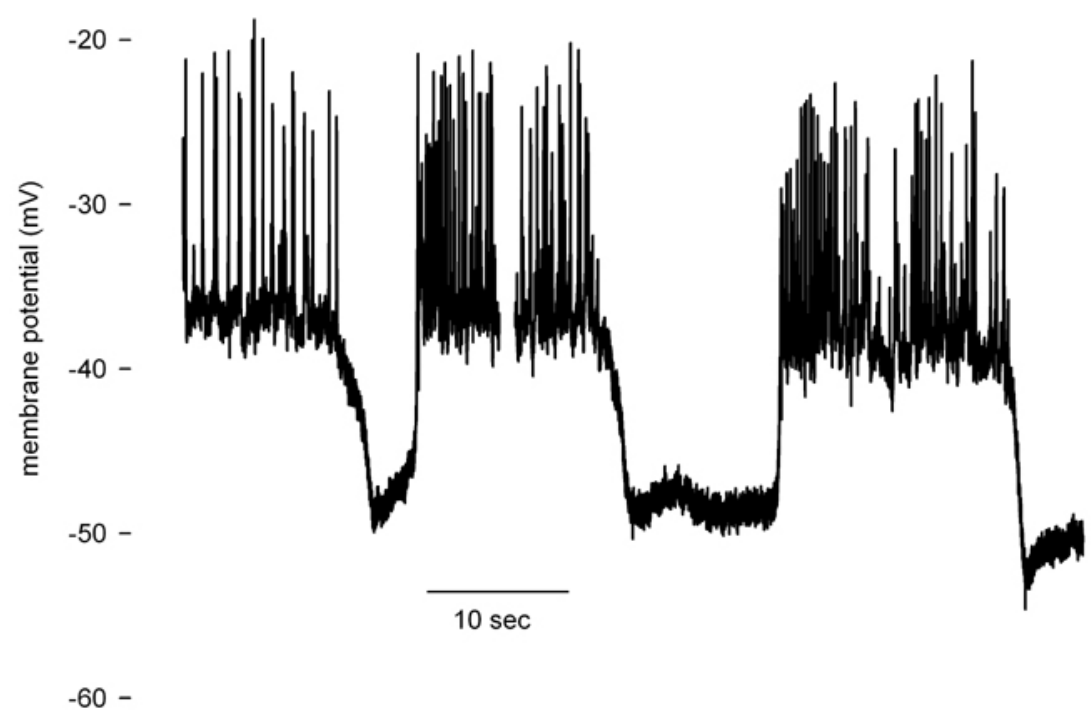

Figure 1: Typical electrical activity bursting pattern of a $\beta$-cell.

Current-clamp recording from a $\beta$-cell in a tissue slice in the presence of $13 \mathrm{mM}$ glucose.

The patch-clamp technique made it possible to demonstrate the channels that contribute to generation of the aforementioned electrical activity. In the 1970s depolarization of pancreatic $\beta$-cells was attributed to a reduction in whole cell $\mathrm{K}^{+}$permeability (Sehlin and Taljedal, 1975; Henquin, 1978) and about 10 years later this depolarization was linked to $\mathrm{K}^{+}$channels that are closed by glucose and ATP (Ashcroft et al., 1984; Cook and Hales, 1984). These ATP regulated $\mathrm{K}^{+}$channels $\left(\mathrm{K}_{\mathrm{ATP}}\right.$ channels) provide the crucial link between metabolic and electrophysiological effects of glucose. At low glucose and 
therefore low ATP concentrations $\mathrm{K}^{+}$ions flow out of the cell through spontaneously active $\mathrm{K}_{\mathrm{ATP}}$ channels. With the $\mathrm{K}^{+}$-gradients existing over the $\beta$-cell membrane this results in a negative membrane potential of around $-70 \mathrm{mV}$. Increasing glucose levels subsequently elevate intracellular ATP and close $\mathrm{K}_{\mathrm{ATP}}$ channels. Thus, via $\mathrm{K}_{\mathrm{ATP}}$ channels the blood glucose concentration controls the $\beta$-cell membrane potential and is able to induce electrical activity. $\mathrm{K}_{\mathrm{ATP}}$ channels also have been identified as the cellular target for sulphonylureas, oral hypoglycemic drugs that have been used in the treatment of type 2 diabetes for many years (Sturgess et al., 1985). The $\beta$-cell $\mathrm{K}_{\mathrm{ATP}}$ channel is a heterooctamer formed from four potassium channel subunits (termed Kir6.2) and four sulphonylurea receptor subunits (SUR1). Both subunits are required to form a functional channel. The Kir6.2 subunits build up the channel pore through which potassium ions flow. SUR1 subunits surround the Kir6.2 subunits, having a regulatory role. ATP binds to the Kir6.2 subunit to close the channel, whereas ADP binding to the SUR1 subunit mediates activation of the channel. The latter subunit also, as implied by its name, binds sulphonylureas, which close the channel, and the $\mathrm{K}_{\mathrm{ATP}}$ channel activator diazoxide (for review see Aguilar-Bryan and Bryan, 1999).

Depolarization due to $\mathrm{K}_{\mathrm{ATP}}$ channel closure initiates electrical activity associated with action potentials. The depolarizing phase of the action potential in $\beta$-cells is attributable to voltage gated $\mathrm{Ca}^{2+}$ channels. These $\mathrm{Ca}^{2+}$ channels are activated at voltages higher than $-40 \mathrm{mV}$ and are sensitive to dihydropyridines such as nifedipine and therefore belong to the class of L-type $\mathrm{Ca}^{2+}$ channels (Rorsman and Trube, 1986). However there is still some controversy regarding the role of other $\mathrm{Ca}^{2+}$ channels as N-type, P/Q-type and Ttype channels have also been detected in insulin-secreting cells (Satin, 2000). 
The repolarization of the action potentials results from the opening of voltage-dependent delayed rectifying $\mathrm{K}^{+}$channels (Smith et al., 1990). In recent studies the Kv2.1 channel was shown to be the main contributor to this voltage-dependent outward $\mathrm{K}^{+}$currents in insulinoma and rodent pancreatic $\beta$-cells (MacDonald et al., 2002). The involvement of other voltage dependent $\mathrm{K}^{+}$channels to electrical activity in $\beta$-cells is not fully revealed. $\mathrm{Ca}^{2+}$-dependent $\mathrm{K}^{+}$channels $\left(\mathrm{K}_{\mathrm{Ca}}\right)$ have been shown to contribute 15 to $20 \%$ of the total voltage-dependent outward current, but their role is unclear as inhibitors of $\mathrm{K}_{\mathrm{Ca}}$ channels failed to affect insulin secretion from rodent islets (Smith et al., 1990; Kukuljan et al., 1991; MacDonald et al., 2002). Furthermore, the voltage-dependent $\mathrm{K}^{+}$channel Kv1.4 was observed in rat $\beta$-cells and abolishing its current, by the expression of a C-terminal truncated form, enhanced glucose stimulated insulin secretion of rat islets (MacDonald et al., 2001).

\subsubsection{Stimulus-secretion coupling in $\beta$-cells}

Electrophysiological studies had major impact in understanding $\beta$-cell function. Together with biochemical methods they revealed a model for stimulus-secretion coupling in $\beta$ cells (Fig. 2). Glucose has to be metabolized in order to stimulate insulin secretion. The blockage of its metabolism was shown to inhibit insulin release (Ashcroft, 1980). Glucose is transported into $\beta$-cells via a facilitated glucose transporter which allows rapid equilibration of extracellular and intracellular glucose concentrations within seconds. In rodents the low affinity glucose transporter GLUT2 has been identified to be responsible for this process. (Johnson et al., 1990). However, in human $\beta$-cells the expression of GLUT2 is markedly lower than the expression of high affinity glucose transporter 
subtypes like GLUT1 and GLUT3 (De Vos et al., 1995). The physiological consequence is not yet clear. Inside the $\beta$-cell glucose is phosphorylated by the glucokinase, acting as 'glucose sensor', coupling insulin secretion to the prevailing glucose level (Van Schaftingen, 1994). Glucose 6-phosphate then undergoes glycolysis and mitochondrial metabolism to produce adenosine triphosphate (ATP). As described above elevated levels of ATP depolarize $\beta$-cell membrane potential by inhibiting $\mathrm{K}_{\mathrm{ATP}}$ channel activity. The initiated electrical activity leads to a flux of $\mathrm{Ca}^{2+}$ ions into the cell via L-type $\mathrm{Ca}^{2+}$ channels increasing the intracellular calcium concentration, thereby triggering granule translocation and exocytosis of insulin containing vesicles (Wollheim and Sharp, 1981). Since the early reports linking $\mathrm{K}_{\mathrm{ATP}}$ channel closure to the exocytotic release of insulin, it has now become apparent that $\beta$-cells also possess a $\mathrm{K}_{\mathrm{ATP}}$ channel-independent stimulussecretion pathway. Under certain experimental conditions that clamp intracellular $\mathrm{Ca}^{2+}$ concentration, glucose is able to increase insulin secretion although $\mathrm{K}_{\mathrm{ATP}}$ channels are unable to close (Gembal et al., 1992) or are continuously closed (Panten et al., 1988). This pathway is termed the amplifying pathway to distinguish it from the triggering pathway that is activated by $\mathrm{K}_{\mathrm{ATP}}$ channel closure. The mechanisms have not been established, although it is believed that the amplifying pathway increases the efficiency of $\mathrm{Ca}^{2+}$ on exocytosis. However, the amplifying pathway is clearly dependent on elevated $\mathrm{Ca}^{2+}$ concentrations, but is not mediated by any further rise in $\mathrm{Ca}^{2+}$ (Gembal et al., 1993). Additionally it is evident that glucose has to be metabolized to exert its amplifying effect (Detimary et al., 1994).

Glucose stimulated insulin release is biphasic, comprising a rapid first phase lasting 5 10 min, followed by a prolonged second phase, which continues for the duration of the 
stimulus. It has been proposed that the triggering pathway is responsible for initiating the first phase and the amplifying pathway to cause the second phase (Taguchi et al., 1995).

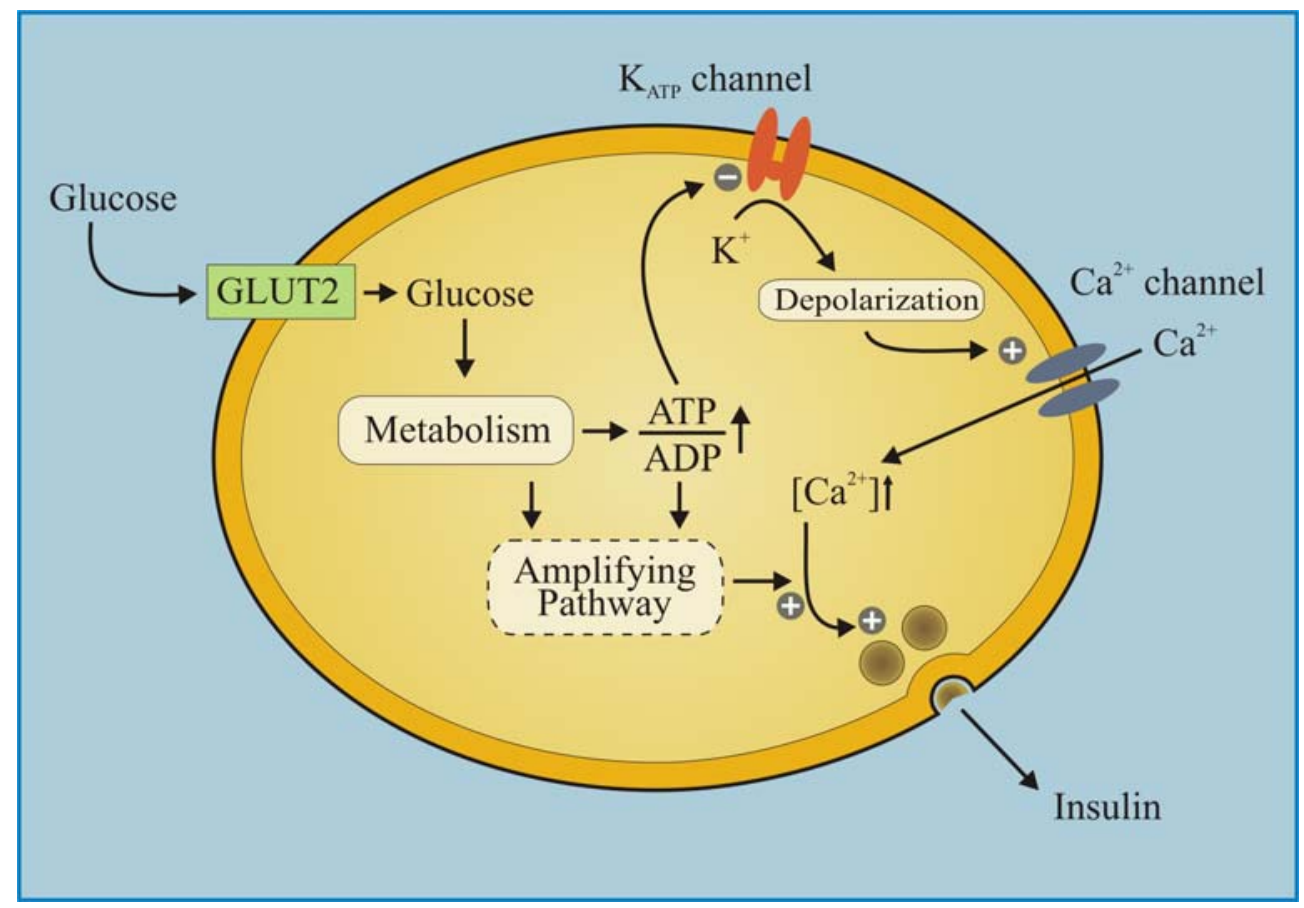

Figure 2: Stimulus-secretion coupling in $\beta$-cells

\subsection{Modulation of insulin secretion}

Major progress has been made regarding the molecular mechanisms of secretory events in pancreatic $\beta$-cells in the past several years. Yet the study of the in vivo physiology of insulin release has revealed an unsuspected degree of complexity, not always apparent when investigating dispersed $\beta$-cells and isolated islets. Several structures, hormones and neural stimuli are considered to be responsible for this phenomenon by modulating the secretion of insulin. 


\subsubsection{Gap junction channels}

Gap junctions are specialized structures connecting neighboring cells, enabling communication via ions, second messengers and small metabolites (Bruzzone et al., 1996). Cells of the islet of Langerhans were also reported to be interconnected by gap junctions (Orci et al., 1973b) and typical gap junction plaques between different types of islet cells were observed (Orci et al., 1975). However, this contrasts with recent investigations indicating the absence of calcium signal synchronization and electrical coupling between $\beta$ - and non- $\beta$-cells and between $\alpha$ - and $\delta$-cells (Gopel et al., 1999; Nadal et al., 1999; Quesada et al., 1999). Several reports suggest that gap junctionmediated communication between $\beta$-cells is required for the control of insulin secretion. Glucose-induced stimulation of single $\beta$-cells is reduced compared to cell clusters (Bosco and Meda, 1991) and pharmacological blockage of gap junction channels markedly decreases insulin release (Meda et al., 1990). Furthermore, physiological heterogeneity found in individual $\beta$-cells is switched to a coordinated and synchronized behavior because of $\beta$-cell communication (Santos et al., 1991). Gap junction channels posses an exceptional structure spanning the plasma membrane of two adjacent cells. Each cell contributes one half of the channel, called connexon. Two connexons act in the extracellular space to form the complete gap junction, allowing for direct communication between the cytoplasm of the participating cells. Each connexon is build up by the oligomerization of connexins, a family of highly related structural proteins, expressed in almost every mammalian cell type (Bruzzone et al., 1996). So far 17 connexin genes have been described and characterized in the murine genome. For most of them, orthologs in the human genome have been found (Willecke et al., 2002). In mouse $\beta$-cells gap 
junctions are composed of connexin proteins of $36 \mathrm{kDa}$ size (Cx36) (Serre-Beinier et al., 2000), forming gap junctions channels with some unique features. First, these gap junctions exhibit the smallest unitary conductance value for gap junctions known to date. This may allow a more precise control of the extent of electrical coupling, by varying channel number. Additionally, Cx36 gap junctions lack voltage sensitivity which prevents uncoupling during electrical activity (Srinivas et al., 1999). Thus, the features of Cx36 gap junctions favor a role in electrical coupling and this has been well documented (Eddlestone et al., 1984). Metabolic communication is known for several gap junction subtypes but still a matter of debate for Cx36 gap junctions. Despite the low unitary conductance $\beta$-cell gap junction channels were reported to be permeable to injected dyes (Michaels and Sheridan, 1981) and metabolites (Kohen et al., 1979). Contrariwise, other reports observed no significant dye coupling in electrically coupled islet cells (PerezArmendariz et al., 1991; Quesada et al., 2003).

\subsubsection{Influence of paracrine hormone secretion}

Intraislet interactions are thought to play an important role in the maintenance of glucose homeostasis. Via paracrine effects of adjacent cells insulin secretion may be modulated by the other islet cells. Especially the main hormone products of $\alpha$-, $\delta$ - and PP cells were studied for their influence on insulin secretion (Weir and Bonner-Weir, 1990). Glucagon secretion from $\alpha$-cells is regulated by nutrients, islet and gastrointestinal products and the autonomic nervous system (Lefebvre, 1995). The effect on insulin secretion has been reported as a powerful stimulation (Pipeleers et al., 1985), but recent experiments suggest that glucagon secreted from islet $\alpha$-cells seems to be unlikely to influence the acute 
glucose-induced insulin secretion (Moens et al., 2002). Somatostatin is expressed in cells of numerous tissues including neurons, $\mathrm{D}$ cells of the gastrointestinal tract and $\delta$-cells of the islet. Various physiological effects of somatostatin on hormone secretion and gastrointestinal function have been reported. Insulin secretion is strongly inhibited via the activation of a specific somatostatin receptor subtype on the $\beta$-cell membrane (Strowski et al., 2003). For the product of islet PP-cells, pancreatic polypeptide, no physiological important role could be established so far. In particular it does not appear to influence the secretion of the other islet hormones (Degano et al., 1992). Finally, insulin was reported to inhibit its own secretion via an autoregulatory feedback mechanism (Khan et al., 2001).

Several other peptides and neurotransmitters have been shown to be coexpressed and secreted together with the main hormones in $\alpha$-, $\beta$ - and $\delta$-cells. Among those are the islet amyloid polypeptide (IAPP), pancreastatin, Diazepam-binding inhibitor (DIP), peptide YY (PYY), atrial natriuretic peptide (ANP), the biogenic amines dopamine and 5hydroxytryptamine (5-HT, serotonin) and many more (Flatt, 2003). For some of them an effect on islet-cell secretion was reported but in most cases the physiological role is not revealed.

\subsubsection{Neuronal regulation of insulin release}

The autonomous nervous system with parasympathetic and sympathetic nerves is an important modulator of islet cell hormone secretion and especially neural control of insulin secretion attracts increasing attention. Activation of parasympathetic nerves before and during feeding is believed to underlie the cephalic phase of insulin release 
(Berthoud et al., 1981). Pancreatic ganglia are supposed to govern the synchronicity of insulin secretion between islets observed over the whole pancreas (Stagner and Samols, 1985). Furthermore, sympathetic activity was reported to regulate the homeostasis of glucose by adjusting insulin secretion to situations of stress, including exercise and hypovolaemia (Jarhult and Holst, 1978; Jarhult and Holst, 1979).

Islets of Langerhans are densely innervated by nerve fibres, which enter the islets with the vessels, forming a peri-insular network in the mantle zone or passing directly to an endocrine cell. Sometimes more than three nerve terminals were found to approach a single endocrine cell (Esterhuizen et al., 1968; Orci et al., 1973a). Studies on the islet innervating fibres with histochemical and fluorescence staining revealed not only nerves containing the classical neurotransmitter acetylcholine and norepinephrine (Coupland, 1958; Cegrell, 1968), but also a variety of established and putative neuropeptides (Sundler and Boucher, 1991).

Cholinergic innervation is relatively abundant in islets, as choline acetyltranferase was shown to have a tenfold higher concentration in isolated islets than in pancreatic tissue as a whole (Godfrey and Matschinsky, 1975). The cholinergic nerve fibres innervating islets of Langerhans are of postganglionic origin and emanate from the intrapancreatic ganglia. These ganglia are controlled by preganglionic fibres, originating primarily in the dorsal motor nucleus of the vagus (Brunicardi et al., 1995). Electrical activation of the vagus was shown to stimulate insulin secretion in several different species (Bloom and Edwards, 1981; Holst et al., 1981; Ahren and Taborsky, 1986). The transmitter conveying this signaling is acetylcholine, which is released by the postganglionic nerve fibres upon vagus activation. Acetylcholine directly stimulates the secretion of insulin 
and of the other three islet hormones, glucagon, somatostatin and pancreatic polypeptide (Iversen, 1973; Ahren et al., 1986). Therefore it seems to be confirmed that the parasympathetic nervous system affects secretion of islet hormones by a general stimulatory action. Acetylcholine binding to muscarinic receptors on the plasma membrane of the islet cells mediates this effect (Ahren et al., 1990b). At present five different muscarinic receptor subtypes ( $\mathrm{M}$ receptor) are known (Caulfield and Birdsall, 1998). However, in mice only the M3 receptor was found to be important for the cholinergic stimulation of glucagon and insulin secretion (Karlsson and Ahren, 1993; Duttaroy et al., 2004).

Several studies have shown that islet hormone secretion induced by vagus stimulation is not fully inhibited by muscarinic antagonists, indicating the presence of a non-cholinergic mechanism of parasympathetic nerves (Holst et al., 1981; Ahren et al., 1986; Ahren and Taborsky, 1986). Three neuropeptides were discovered in nerve terminals in pancreatic ganglia and in islets in several different species: vasoactive intestinal polypeptide (VIP), gastrin releasing peptide (GRP) and pituitary adenylate cyclase activating polypeptide (PACAP). These neuropeptides are released from the pancreas on electrical stimulation of the vagus and stimulate both insulin and glucagon secretion (Knuhtsen et al., 1987; Fridolf et al., 1992; Havel et al., 1997). Both, morphological and functional characteristics lead to the assumption that these neuropeptides are contributors of parasympathetic action on islet hormone secretion.

Islets of Langerhans also receive a rich supply of sympathetic nerves. Immunochemistry studies observed an intensive staining for the enzyme tyrosine hydroxylase, which is necessary for noradrenaline formation (Ahren et al., 1981). Adrenergic nerves 
innervating the islet are postganglionic with most nerve cell bodies located in the celiac ganglion or the paravertebral sympathetic ganglia. The preganglionic nerve fibres originate from nerve cell bodies in the hypothalamus (Brunicardi et al., 1995). Electrical stimulation of the splanchnic nerve can be used to examine the effects on hormone secretion after sympathetic nerve activation. The result of such stimulation is the inhibition of glucose induced insulin secretion (Kurose et al., 1990; Brunicardi et al., 1995), but also basal insulin secretion has been found to be inhibited in some species (Bloom and Edwards, 1984; Ahren et al., 1987). Inhibition of glucose stimulated insulin secretion can be mimicked by the application of noradrenaline. This is mediated by the activation of $\alpha_{2}$-adrenoceptors situated on the $\beta$-cell membrane. However, noradrenaline is not responsible for the inhibition of basal insulin secretion upon sympathetic nerve stimulation (Porte and Williams, 1966; Ahren and Taborsky, 1988). This non-adrenergic contribution of sympathetic inhibition of insulin secretion is possibly carried by the neuropeptide galanin, neuropeptide Y (NPY) or both. Supporting evidence arises from several different species in which these neuropeptides are co localized to the adrenergic marker, tyrosine hydroxylase (Dunning et al., 1986; Ahren et al., 1990a). NPY and galanin have both been reported to inhibit insulin release (Moltz and McDonald, 1985; Dunning et al., 1986), but there seems to be a profound difference between species in their localization and effect (Ahren, 2000).

Besides the inhibitory effect on insulin secretion sympathetic nerves also affect the secretion of the other islet hormones. Glucagon and PP secretion are stimulated upon activation of sympathetic nerves whereas the release of somatostatin is inhibited (Holst et al., 1983; Bloom and Edwards, 1984; Kurose et al., 1990). 
Apart from parasympathetic and sympathetic nerves also several other fibres innervate the islets of Langerhans, although their contributions to control islet hormone secretion are unclear. Nerves with terminals harboring the sensory neuropeptides, calcitonin generelated peptide (CGRP) and substance P (SP) have been observed (Sternini and Brecha, 1986; Karlsson et al., 1992). However, their actions are not clear, as all kinds of effects have been observed, depending on the dosage and animal species studied. This holds for substance P (Lundquist et al., 1979; Chiba et al., 1985; Adeghate et al., 2001) as well as for CGRP (Pettersson et al., 1986; Yamaguchi et al., 1990; Edwards and Bloom, 1994). Cholecystokinin (CCK) is also localized to islet nerves and perhaps is of importance for insulin secretion because it was reported to be a potent stimulator of insulin release (Rehfeld et al., 1980). Furthermore, nerve fibres stained for nitric oxide synthase indicate a possible contribution of nitric oxide on insulin secretion (Ekblad et al., 1994). Finally, it has been shown that nerves originating in ganglia in the duodenum might pass directly to the pancreas and innervate pancreatic ganglia, suggesting the existence of a direct enteropancreatic neural mechanism (Kirchgessner and Gershon, 1990). The role of these nonsympathetic and non-parasympathetic nerves in the modulation of islet hormone secretion has to be explored in the future.

\subsubsection{The incretin effect}

The observation that food ingestion or enteral glucose administration provoke a greater stimulation of insulin release compared with similar amounts of glucose infused intravenously led to the development of the incretin concept (Elrick et al., 1964). Experiments showed that up to $60 \%$ of the insulin secretory response after an oral 
glucose load are not caused by a direct action of glucose with $\beta$-cells, but by the secretion and insulinotropic action of gut peptides, so-called incretins (Creutzfeldt, 1979; Nauck et al., 1986b). Although there are probably many postprandial released hormones with an effect on insulin secretion, the available experimental data suggests that the two most important ones are glucose-dependent insulinotropic polypeptide (GIP) and glucagon-like peptide-1 (GLP-1) (Fehmann et al., 1995). GIP is secreted from specific endocrine cells, the $\mathrm{K}$ cells, which exhibit the highest density in the duodenum, but are also found in the entire small intestinal mucosa (Mortensen et al., 2000). The primary role of GIP is to stimulate insulin secretion in a glucose-dependent manner (Dupre et al., 1973). GLP-1 is secreted by L-cells of the intestinal mucosa, one of the most abundant endocrine cells in the gut (Mojsov et al., 1986). It is known as a highly potent insulin releasing substance (Kreymann et al., 1987) and was also shown to inhibit glucagon secretion (Matsuyama et al., 1988). The physiological relevance of incretins for glucose homeostasis has been suggested by studies that observed a severely reduced incretin effect in type 2 diabetes patients (Nauck et al., 1986a).

\section{5. $\quad \beta$-cell preparations}

Experiments performed on $\beta$-cells changed immense during the last 40 years due to improvements in the preparations and the methods used. In the beginning pieces of pancreas (Coore and Randle, 1964) and isolated pancreas (Sussman et al., 1966) were used to measure the insulin release in rodents and enabled the discovery of inorganic cation requirement for insulin secretion (Hales and Milner, 1968). The first recordings of

electrical activity of $\beta$-cells were done in intact mouse islets exposed from pancreatic 
tissue by micro-dissection (Dean and Matthews, 1968). These studies, performed with intracellular microelectrodes, revealed that $\beta$-cells respond to a variety of stimulators of insulin release with the induction of a characteristic pattern of electrical activity (Henquin and Meissner, 1984). A great simplification for the study of $\beta$-cells was the development of the isolation procedure for islets of Langerhans from the pancreas by enzymatic digestion (Lacy and Kostianovsky, 1967) and the possibility to obtain cell suspensions of single islet cells (Lernmark, 1974). Additionally the development of the patch-clamp technique enabled the measurement of ionic currents underlying electrical activity in small cells like single $\beta$-cells (Hamill et al., 1981). This revolutionized the understanding of the mechanisms underlying the stimulation of insulin release by nutrients and pharmacological agents (Ashcroft and Rorsman, 1989).

However, studies on dispersed single $\beta$-cells imply removal of the cells from their natural environment, the islet of Langerhans. Differences in the electrical activity of single $\beta$ cells and $\beta$-cells in intact islets indicate the disadvantage of disrupting $\beta$-cells from their adjacent cells. $\beta$-cells in intact islets show a characteristic bursting pattern, but in single $\beta$-cells most investigators observed only exhibition of irregular, apparently random spiking with periods of abnormal long active phases (Rorsman and Trube, 1986; Larsson et al., 1996). As a result of diverse electrical activity in single $\beta$-cells and $\beta$-cells in intact islets also $\mathrm{Ca}^{2+}$ concentration changes display different patterns depending on the preparation (Zhang et al., 2003). Therefore it is not surprising that single $\beta$-cells were discovered to exhibit poor secretory activity compared to intact islets of Langerhans (Pipeleers et al., 1982). In 1999 Göpel et al. presented a new approach to study ionic currents of $\beta$-cells in intact islets with the patch-clamp technique. Most 
electrophysiological properties of the $\beta$-cell in intact mouse islets confirm those established in single-cell studies. Interestingly, the amplitude of the peak $\mathrm{Ca}^{2+}$-current of $\beta$-cells in intact islets is almost twice that observed in isolated cells, perhaps contributing to the higher stimulated insulin release from intact islets. In addition half-maximal inhibition of $\mathrm{K}_{\mathrm{ATP}}$ channels by glucose in $\beta$-cells in intact islets differs significantly from the value obtained for single cells (Gopel et al., 1999). These studies reveal the negative impact of removing $\beta$-cells from their natural environment and point out how important the physiological condition of the preparation is. Considering that isolated islets are as well removed from the surrounding tissue raises the question if this intrusion also alters the properties of islet hormone secretion. Supportive data for this assumption was observed in several studies comparing hormone secretion of isolated islets and perfused pancreas. Insulin release from perfused pancreas was reported to have a lower basal secretion rate (Weir et al., 1986), a lower threshold for glucose to elicit a rapid and distinct insulin response (Nesher and Cerasi, 2002) and a higher range of the response amplitude (Cerasi, 1992). This indicates that $\beta$-cells in isolated islets still show many differences to in vivo $\beta$-cell function.

In various organs tissue slices have been used for several decades as an in vitro system to study organ function close to in vivo conditions. Today the employment of automated slicer make it possible to produce tissue slices in a rapid and reproducible way (Parrish et al., 1995). Additionally, the development of organotypic slice culture enabled the use of tissue slices for long-term experiments in physiology, pharmacology, morphology and development (Gahwiler et al., 1997). Especially in brain research tissue slices evolved as the predominant in vitro preparation used by electrophysiologists, pharmacologists and 
biochemists (Lynch and Schubert, 1980). But also slices of several other tissues like kidney (Ruegg, 1994), lung (Freeman and O'Neil, 1984), liver (Gandolfi et al., 1996) and spleen (Skibinski and James, 1997) were used to reveal physiological properties and function of the intact organ. Since slices are easy to prepare and because they retain the cytoarchitecture of the tissue of origin they are considered as the in vitro model system nearest to in vivo conditions. From an experimental and complexity point of view only perfused organs are closer to whole organism. However, perfused organs limit the possibility to study function at a cellular level.

\subsection{Aim of this work}

Goal of the present study was to develop a technique to prepare tissue slices of mouse pancreas in a reproducible and rapid way to study $\beta$-cell function. General anatomy of the slice as a whole and especially of the structures related to islets of Langerhans should be documented. Of major interest was the electrophysiological characterization of $\beta$-cells in an environment close to natural conditions. Thereby, after ensuring viability and functionality, emphasis was placed on differences in $\beta$-cell properties in the tissue slice compared to other preparations used in the investigation of $\beta$-cell function. At last a part

of the study was performed on transgenic animals to reveal the impact of gap junctions to the proper function of $\beta$-cell activity. 


\section{Material and Methods}

\subsection{Animals}

All animals were kept under standard housing conditions with free access to water and food. Experiments were conducted according to the regulations of our institutional and state committees on animal experiments. Male and female adult NMRI mice were used to study morphological and general features of pancreatic tissue slices. To visualize neuronal tissue in the pancreatic slices, transgenic mice expressing the enhanced yellow fluorescent protein (EYFP) under the control of the neuron-specific Thy1.2-promoter were studied (Hirrlinger et al., 2004). These mice were obtained from the laboratory of Dr. Frank Kirchhoff (MPI für experimentelle Medizin, Göttingen, Germany). For the study of the gap junction influence on electrical activity, connexin36-deficient C57Bl/6 mice (Guldenagel et al., 2001) were obtained from the laboratory of Prof. Dr. Klaus Willecke (Institute of Genetics, University of Bonn, Germany). In electrophysiological experiments only male adult mice were included.

\subsection{Solutions}

The standard extracellular solution used for slicing and all experiments consisted of (mM): $125 \mathrm{NaCl}, 2.5 \mathrm{KCl}, 26 \mathrm{NaHCO}_{3}, 1.25 \mathrm{NaH}_{2} \mathrm{PO}_{4}, 2 \mathrm{Na}$ pyruvat, 0.5 or 0.25 ascorbic acid, 3 myo-inositol, 6 lactic acid, $1 \mathrm{MgCl}_{2}$ and $2 \mathrm{CaCl}_{2}$. The glucose concentration during preparation and during the experiments was $3 \mathrm{mM}$ if not indicated differently. Tolbutamide and diazoxide stock solutions were prepared in Dimethyl 
sulfoxide (DMSO) and added to a final concentration of $100 \mu \mathrm{M}$. The pipette filling solution contained (in mM) $150 \mathrm{KCl}, 10$ Hepes (pH 7.2 with $\mathrm{KOH}$ ), $2 \mathrm{MgCl}_{2}, 0.05$ or 5 EGTA and ATP as indicated. All chemicals used were purchased from Sigma (USA) unless otherwise indicated.

\subsection{Preparation procedures}

\subsubsection{Preparation of dispersed $\beta$-cells}

Mice were killed by cervical dislocation. Immediately afterwards the abdominal cavity was opened and the bile duct was dissected from surrounding connective tissue. Liberase (Roche, USA) was dissolved in Hank's buffer solution (Invitrogen, USA) and injected into the pancreas via the distally clamped bile duct. The pancreas was then removed and digested for $20-30 \mathrm{~min}$ at $37{ }^{\circ} \mathrm{C}$. Islets were first enriched by Ficoll gradient centrifugation (Amersham, Sweden) and then hand picked. Isolated islets were shaken in CMRL-1066 medium supplemented with $10 \%$ fetal bovine serum (Invitrogen, USA) plus $2 \mathrm{mM}$ EGTA and triturated into single cells. Cells were plated onto poly-Lornithine-coated coverslips and cultured in CMRL-1066 medium supplemented with 10

$\%$ fetal bovine serum (Invitrogen, USA), 100 units $/ \mathrm{ml}$ penicillin $\mathrm{G}$ and $0.1 \mathrm{mg} / \mathrm{ml}$ streptomycin in a humidified atmosphere of $5 \% \mathrm{CO}_{2} / 95 \% \mathrm{O}_{2}$ at $37{ }^{\circ} \mathrm{C}$. Cultured cells were used within 1 day. 


\subsubsection{Preparation of pancreatic tissue slices}

Like in the procedure to isolate islets mice were prepared to inject a substance into the pancreas via the bile duct. Low gelling agarose (Seaplaque ${ }^{\circledR}$ GTG $^{\circledR}$ agarose, BMA Products, USA; $0.475 \mathrm{~g}$ in $25 \mathrm{ml}$ extracellular solution), was melted and kept at $37^{\circ} \mathrm{C}$. Agarose was injected into the distally clamped bile duct. After injection the pancreas was cooled down fast with ice cold extracellular solution. Injected and hardened pancreas was extracted, placed in an ice cold extracellular solution and if necessary supported with subcapsular injections of agarose. The tissue was inserted into a small dish filled with agarose and immediately cooled down on ice. A small cube was cut out of the agarose embedded pancreatic tissue and glued (Super Glue ${ }^{\mathrm{TM}}$, ND Industries, USA) onto the probe plate of the vibrotome ( VT $1000 \mathrm{~S}$, Leica, Germany). The tissue was sliced at a speed of $0.05 \mathrm{~mm} / \mathrm{sec}$ at $70 \mathrm{~Hz}$ to $130-150 \mu \mathrm{m}$ thick slices. During slicing and afterwards for storage the tissue slices were kept in ice cold extracellular solution, continuously bubbled with carbogen. Before starting the experiments slices were incubated for at least $30 \mathrm{~min}$ at $32^{\circ} \mathrm{C}$ in carbogen-bubbled extracellular solution.

\subsection{Insulin measurements}

To measure insulin release from the perfused slices we pooled about 10 slices, together containing 25 to 30 islets. Slices were incubated in extracellular solution with low or high glucose concentrations. Every minute the extracellular solution was changed and collected to measure the amount of secreted insulin per minute. The insulin content was measured by ultrasensitive mouse insulin enzyme-linked immunosorbent (ELISA) assay (Mercodia, Sweden). 


\subsection{Imaging}

The gross morphology of the acute tissue slices was studied using wide-field microscopy (Axioskop 2 and AxioCam; Zeiss, Germany) and stereomicroscopy (SZX9; Olympus, Japan; Coolpix 995; Nikon, Japan). For immunocytochemistry freshly prepared tissue slices were fixed and permeabilized with $4 \%$ paraformaldehyde and $0.3 \%$ Triton X-100 in PBS for $1 \mathrm{~h}$ at room temperature. The slices were incubated with the primary antibodies (mouse anti-insulin and rabbit anti-glucagon; Dako, USA) for $2 \mathrm{~h}$ at $37{ }^{\circ} \mathrm{C}$. After washing with PBS, incubation with the secondary antibodies (Alexa 488 goat antimouse and Alexa 647 goat anti-rabbit; Molecular Probes, USA) followed, for either $2 \mathrm{~h}$ at $37{ }^{\circ} \mathrm{C}$ or overnight at $4{ }^{\circ} \mathrm{C}$. Bleaching was reduced with the SlowFade Light Antifade Kit (Molecular Probes). Blood vessels were visualized by incubating the fresh slices for $2 \mathrm{~h}$ at $37^{\circ} \mathrm{C}$ with the panendothelial antibody (Pharmingen, USA). After washing with PBS the secondary antibody (Alexa 488 goat anti-mouse) was added for $45 \mathrm{~min}$ at $37^{\circ} \mathrm{C}$. Cell viability in the tissue slices was assessed with the Live/Dead kit (Molecular Probes). The immunocytochemical preparations were examined using laser scanning confocal microscopy. Confocal microscopy allows focusing a point source of light deep into cells and tissues and then to image the light signal emitted from this point. This is achieved by the scanning of a laser over the image plane and collecting the light through the objective, which focuses it onto a small aperture (pinhole) behind which the photodetector is situated. In this study the confocal microscope TCS SP2 (Leica, Germany) was used, applying $488 \mathrm{~nm}(\mathrm{Ar}), 543 \mathrm{~nm}(\mathrm{He}-\mathrm{Ne})$ and $633 \mathrm{~nm}(\mathrm{He}-\mathrm{Ne})$ laser for excitation. Emission was detected at 505-530 nm (green channel), and $>656 \mathrm{~nm}$ (red channel). The pinhole was adjusted to match the size of one airy unit for each objective and wavelength 
by the "Airy 1" function of the software. Excitation cross-talk was minimized by sequential scanning and to increase the signal-to-noise ratio scanning was performed as four-time line averaging. To acquire a three-dimensional image of the specimen a stack of two-dimensional images along the z-axis was taken. Images were processed using the manufacturer's confocal software (Leica).

\subsection{Electrophysiology}

Cells from the second or the third layer in the islets were used for electrophysiological recording to increase the probability of finding $\beta$-cells. $\beta$-cells were identified by their $\mathrm{Na}^{+}$-current inactivation pattern (Gopel et al., 1999) and the change in membrane potential in the presence of elevated glucose in the extracellular solution (Ashcroft and Rorsman, 1989). The slices were transferred from the incubation beaker to the perfusion chamber and held on the bottom by a nylon-fiber net in a U-shaped platinum-wire frame. The perfusion chamber was mounted on an upright microscope (objectives 10x, NA 0.3; 60x W, NA 0.9, Eclipse E600FN; Nikon, Japan). During experiments the slices were superperfused continuously with carbogen-bubbled extracellular solution $\left(32{ }^{\circ} \mathrm{C}, 1.5\right.$ $\mathrm{ml} / \mathrm{min})$.

The patch-clamp technique allows to measure membrane currents (voltage-clamp) and alternatively to monitor changes in the membrane potential (current-clamp). In both cases a glass microelectrode (pipette) is tightly sealed onto the plasma membrane of the cell, thereby isolating a small area (patch). The resistance between the pipette and the plasma membrane (seal resistance) is crucial for the determination of small ionic currents in the picoampere range and should typically exceed $10^{9} \Omega$ (gigaseal). Currents flowing through 
ion channels inside the interior of the pipette are measured by a connected patch-clamp amplifier. This so-called "cell-attached" configuration enables the study of single channel activity in a noninvasive way and was the precursor to all other variants of the patchclamp technique. The other configurations either record from membrane patches and differ in the orientation of the plasma membrane to the bath solution, or measure wholecell currents and differ in the way to gain access to the cell. In this thesis all experiments were performed in the standard whole-cell patch-clamp configuration.

Exocytosis was studied by monitoring cell capacitance changes. Since the cell capacitance is proportional to its surface area $\left(10 \mathrm{fF} / \mu \mathrm{m}^{2}\right)$, any membrane added by exocytosis or removed by endocytosis is detected as capacitance change. To estimate the changes in membrane capacitance the piecewise-linear technique was used (Neher and Marty, 1982). A patch-clamp lock-in amplifier (SWAM II, Celica, Slovenia) operating at $1.6 \mathrm{kHz}$ lock-in frequency was used. Upon establishment of the whole-cell configuration, the membrane capacitance $\left(\mathrm{C}_{\mathrm{m}}\right)$ and the access conductance $\left(\mathrm{G}_{\mathrm{a}}\right)$ were compensated by $\mathrm{C}_{\mathrm{m}}$ and $\mathrm{G}_{\mathrm{a}}$ compensation controls. A sine voltage of $11 \mathrm{mV}$ rms was applied. The phase angle setting was determined by applying a $1 \mathrm{pF}$ pulse and monitoring the projection of the pulse from the $\mathrm{C}$ (signal proportional to $\mathrm{C}_{\mathrm{m}}$ ) to $\mathrm{G}$ outputs of the lock-in amplifier. $\mathrm{C}_{\mathrm{m}}$, $\mathrm{G}_{\mathrm{a}}$, membrane current and membrane potential were recorded after filtering $(300 \mathrm{~Hz}$, 4pole Bessel). The unfiltered membrane current, C, G, membrane potential and photometry output signal were stored simultaneously (digitizer: DRA-400; Bio Logic, France; CD: PDR-W739, Pioneer, Japan) for off-line analysis. Data was transferred to a PC via an A/D converter (PCI-6035E, National Instruments, USA). WinWCP software (John Dempster, University of Strathclyde, UK) was used to apply depolarizing pulses 
and to acquire and analyse data. A pulse stimulation protocol that differed from the stimulation protocols employed in many previous $\beta$-cell studies was used to mimic physiological electrical activity (see Fig. 9). For the study of $\mathrm{K}_{\mathrm{ATP}}$ channel conductance and gap junction contribution an EPC9 or EPC10 amplifier (HEKA Electronik, Germany) was employed. Data were acquired at $20 \mathrm{kHz}$ using PULSE v8.65 software (HEKA Electronik) and stored in a PC. Currents were elicited using a voltage ramp from -150 to $+50 \mathrm{mV}$ at a rate of $2 \mathrm{~V} / \mathrm{s}$ in cells held at $-70 \mathrm{mV}$. Conductance was read as a slope of the current-voltage response between -100 and $-60 \mathrm{mV}$ to the voltage ramp. Current-clamp was performed to record the membrane potential changes due to different intracellular ATP concentrations and extracellular stimulating agents using both types of amplifiers. Patch pipettes were pulled (P-97; Sutter Instruments, USA) from borosilicate glass capillaries (GC150F-15; WPI, USA) to a resistance of 2-4 M $\Omega$ in KCl-based solution. Only experiments with a series conductance exceeding $50 \mathrm{nS}$ were processed.

\section{7. $\mathrm{Ca}^{2+}$ measurements}

Fura-6F (Molecular Probes, $0.5 \mathrm{mM}$ in the pipette solution) was used to measure intracellular $\mathrm{Ca}^{2+}$ concentration changes simultaneously with the patch-clamp recordings. Fura-6F was excited at $380 \mathrm{~nm}$ with a monochromator (Polychrome IV; TILL Photonics, Germany). A dichroic mirror centered at $400 \mathrm{~nm}$ reflected the monochromatic light to the perfusion chamber and transmitted the emitted fluorescence which was further filtered through a $420 \mathrm{~nm}$ barrier filter. The fluorescence intensity was measured by a photodiode (TILL Photonics). The filtered signal was recorded (300 Hz, 4-pole Bessel) 
and stored simultaneously with the unfiltered signal and voltage-clamp signals. Intracellular $\mathrm{Ca}^{2+}$ was calculated as described previously (Carter and Ogden, 1994).

Resting intracellular $\mathrm{Ca}^{2+}$ concentrations at different buffering conditions were calculated from ratiometric $(340 \mathrm{mM} / 380 \mathrm{nM})$ imaging of FURA-PE3 ((50 $\mu \mathrm{M})$ TEF Labs, USA) using a CCD camera (Ixon, Andor Technology, Japan) and native Andor software. Calibration constants of FURA-PE3 were obtained by performing in vitro calibration. Free $\mathrm{Ca}^{2+}$ was estimated as described previously (Grynkiewicz et al., 1985).

\subsection{Data analysis}

Analysis was done using PulseFit v8.65 (HEKA Electronik), SigmaPlot v7.0 / v8.0 (Jandel Scientific, USA) and Matview (Wise Technologies, Slovenia). $\mathrm{Ca}^{2+}$ levels were calculated using Matlab routine (Mathworks, Novi, USA). Data are displayed as mean \pm S.E.M. and $\mathrm{n}$ is indicating the number of cells analyzed. The statistical significance was determined by using two-way ANOVA test or student's t-test.

The ATP concentration-dependence inhibition curves for $\mathrm{K}_{\mathrm{ATP}}$ channels were fitted by the function:

$$
\left(K_{\text {ATP }}\right)_{\text {normalized }}=\frac{1}{1+\left(\frac{[A T P]_{i}}{I C_{50}}\right)^{n}}
$$

$[\mathrm{ATP}]_{\mathrm{i}}$ is the ATP concentration in the pipette solution, $\mathrm{IC}_{50}$ is the half-inhibitory $[\mathrm{ATP}]_{\mathrm{i}}$ and $\mathrm{n}$ is the Hill coefficient. 
The run-down of $\mathrm{K}_{\mathrm{ATP}}$ conductance was quantified by fitting the decaying part of the time-dependent $\mathrm{K}_{\mathrm{ATP}}$ conductance curve to a single-exponential decay function:

$\left(K_{A T P}\right)=\left(K_{A T P}\right)_{o}+\left(K_{A T P}\right)_{1} * e^{(-t / \tau)}$

$\left(\mathrm{K}_{\text {ATP }}\right)_{0}$ is the residual $\mathrm{K}_{\text {ATP }}$ conductance, $\left(\mathrm{K}_{\mathrm{ATP}}\right)_{1}$ is the run-down component of $\mathrm{K}_{\text {ATP }}$ conductance and $\tau$ is the time constant. 


\section{Results}

\subsection{Features of mouse pancreatic tissue slices}

Agarose injected inside the ductal system and around the pancreatic tissue stabilized the tissue in the slice and made it mechanically suitable for slicing and transferring. Autolysis due to the digestive enzymes from the exocrine part did not occur and no enzyme inhibitors were needed. This was revealed with the Live/Dead kit showing endocrine cells surviving in the tissue slices for at least 24 hours (data not shown). The good adaptability of the preparation procedure allowed us to adjust the slice dimensions in a wide range. For most experiments in this study, slices of $130-150 \mu \mathrm{m}$ in thickness and about $40-100 \mathrm{~mm}^{2}$ in area were used.

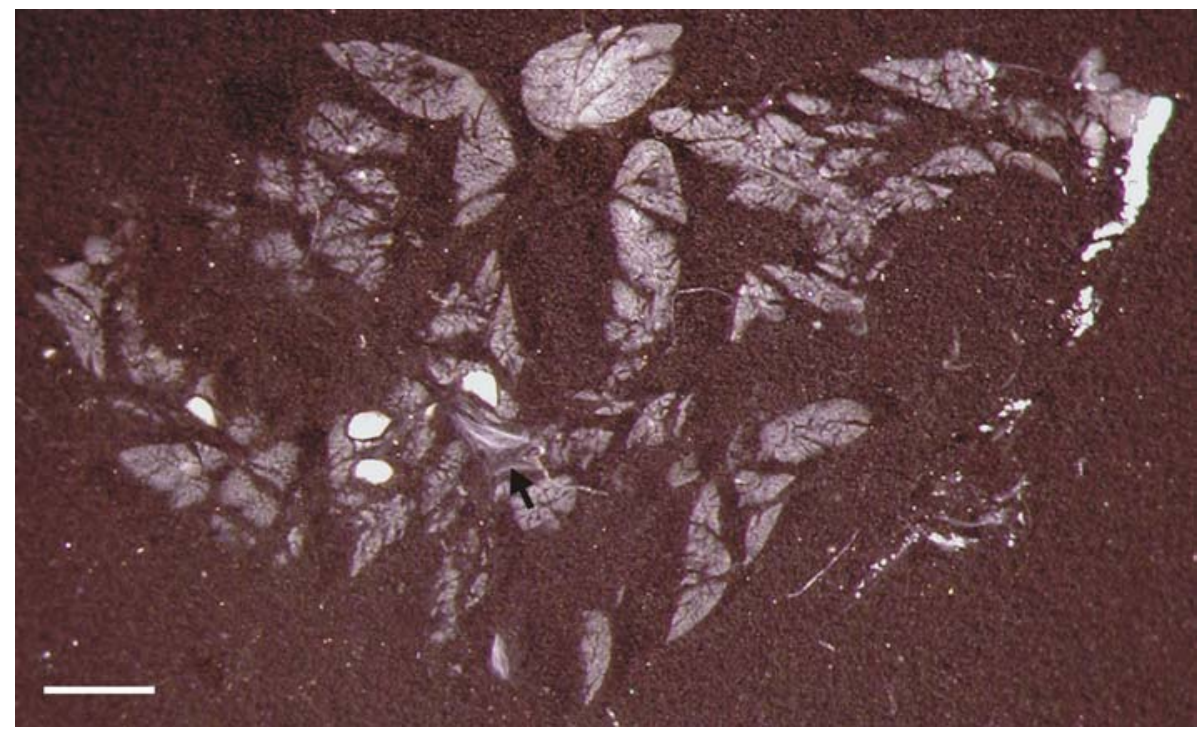

Figure 3: Pancreatic tissue slice.

The major part of the slice consists of exocrine cells. Islets of Langerhans (round structures) and adipose tissue (right edge of the slice) are seen as bright white structures. A large cut blood vessel is indicated by an arrow. Scale bar: $1 \mathrm{~mm}$. 
The three dimensional architecture of the mouse pancreas was well preserved and the typical acinar branches could easily be distinguished (Fig. 3). In pancreas slices we were able to find other tissue types. The major part of the pancreas consisted of large, polarized cells representing the cells of the exocrine part of the pancreas, building up the branches. Longitudinally or transverse cut vessels and ducts were observed in the majority of slices. Adipose tissue was found on the edges of the organ below the capsule and close to ducts and vessels of larger diameter. In reflected light stereomicroscopy islets of Langerhans were revealed inside the slices as bright white structures. Even at low magnification islets of bigger size were already easy to distinguish from the surrounding structures. The number of islets of Langerhans in the average slice varied from zero to ten, irrespective of the part of the pancreas from which the slices were obtained. The size of the islets ranged from $\sim 50$ to $>500 \mu \mathrm{m}$ measuring the longest axis. Capillaries inside the slice could be visualized with the panendothelian antibody showing the stronger vascularization of the islet of Langerhans compared to the surrounding exocrine tissue (Fig. 4). Neuronal structures were visualized by confocal microscopy of transgenic mice expressing the enhanced yellow fluorescent protein (EYFP) under the neuron-specific Thy1.2-promoter (Fig. 5). Ganglia observed in the exocrine tissue constituted of several cells, whereas on islets two or three EYFP-positive cells indicated the presence of a neuroinsular complex (Fujita, 1959). Nerve fibres connected the ganglia and penetrated the islets getting into close contact to the endocrine cells. 


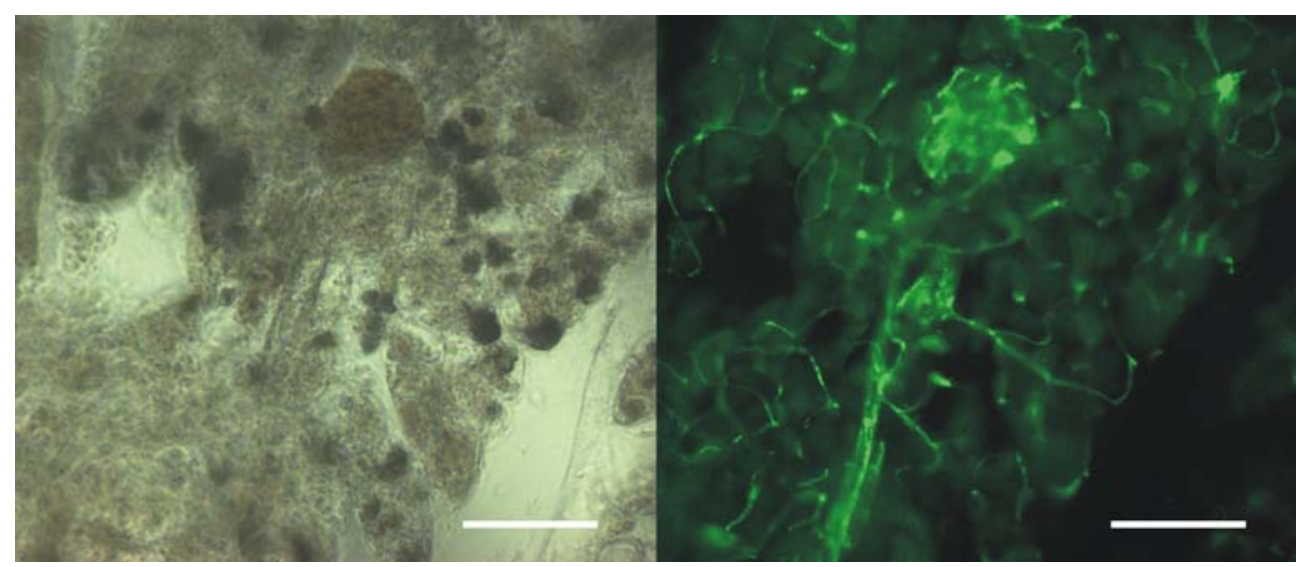

Figure 4: Vascularization of islets.

Left panel: Transmission image of a slice showing exocrine tissue and an islet of Langerhans. Right panel: Fluorescence image of the same slice stained with panendothelian antibody. Scale bar $50 \mu \mathrm{m}$.

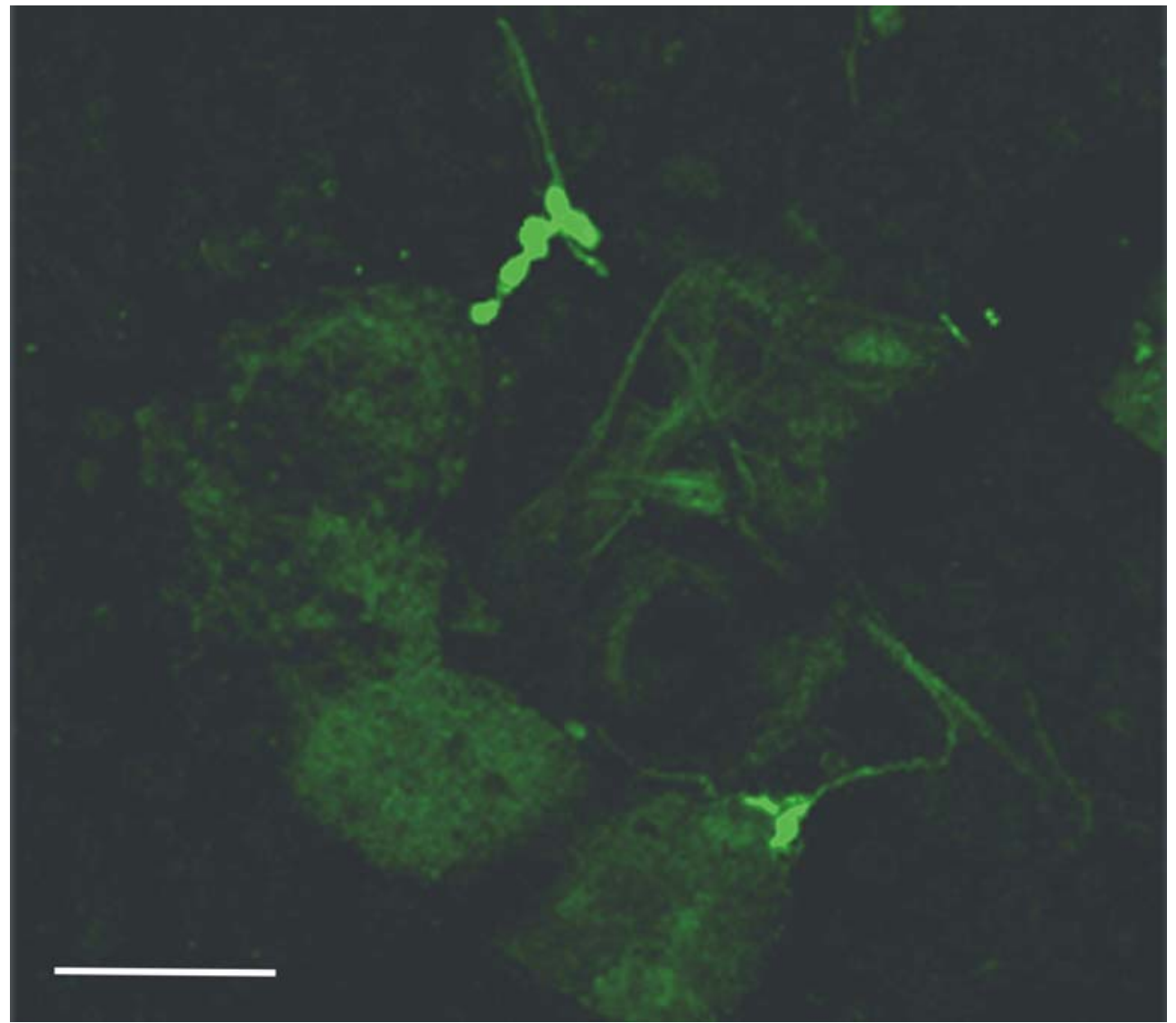

Figure 5: Neuronal structures in slices.

Confocal image of a slice of an EYFP expressing mouse. Local ganglia inside the exocrine part and ganglia on islets appear as bright cells. Nerve fibers are connecting the ganglia. Islets and cut blood vessels appear as dim structures. Scale bar $50 \mu \mathrm{m}$. 
With transmitted light the islets appeared as brownish cell clusters in the surrounding dark green exocrine tissue (Fig. 6). The islets varied strongly in size, shape and structure. About $50 \%$ of the islets were round, like islets isolated using the standard collagenase isolation procedure. However, islets of more complex shapes, especially of ellipsoid shape, were found frequently (Fig. 6). Islets located close to the pancreatic ducts or the blood vessels were often reflected around these structures. The islet cell density also varied. Most islets were densely packed with cells, but almost hollow islets containing fewer cells were also found in adult pancreatic preparations. These islets were not included in the electrophysiological characterization.

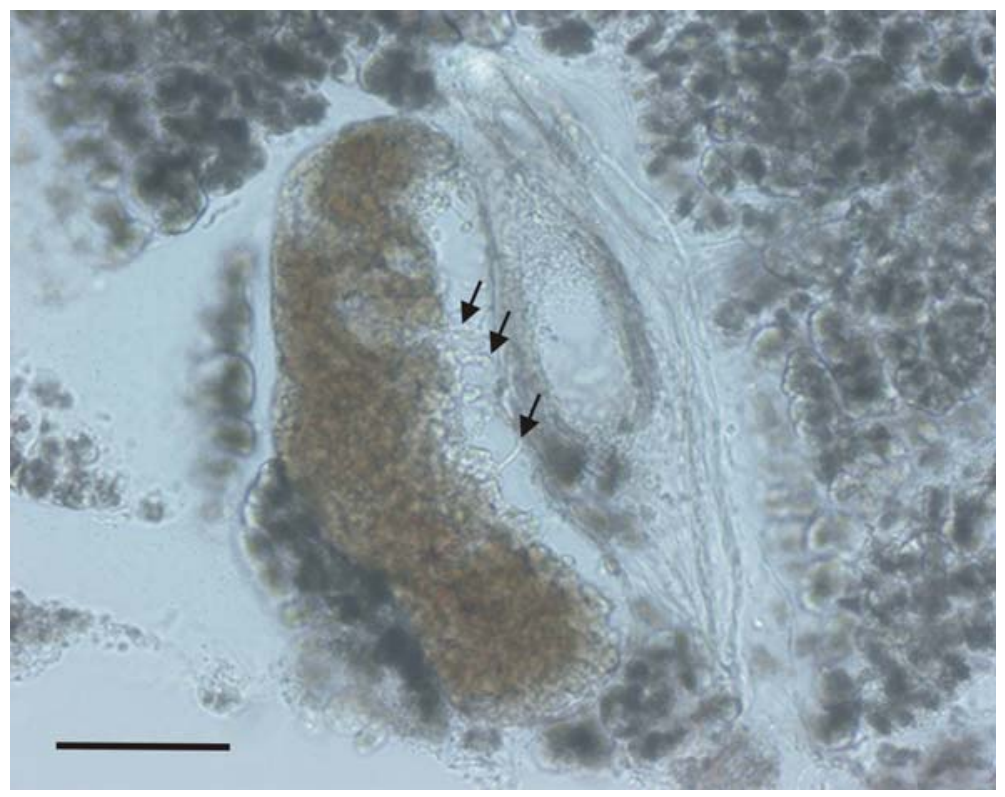

Figure 6: Islet of Langerhans.

Transmitted light micrograph of an islet surrounded by exocrine tissue. Next to the islet are a duct and a cut blood vessel, the latter is connected to the islet via capillaries (arrows). Scale bar $50 \mu \mathrm{m}$. 
Figure 7 shows that the typical microanatomy of the islets was consistent with previous descriptions. The $\beta$-cells were the most abundant cells and made up the core of the islet surrounded by non- $\beta$-cells in the periphery of the islet.

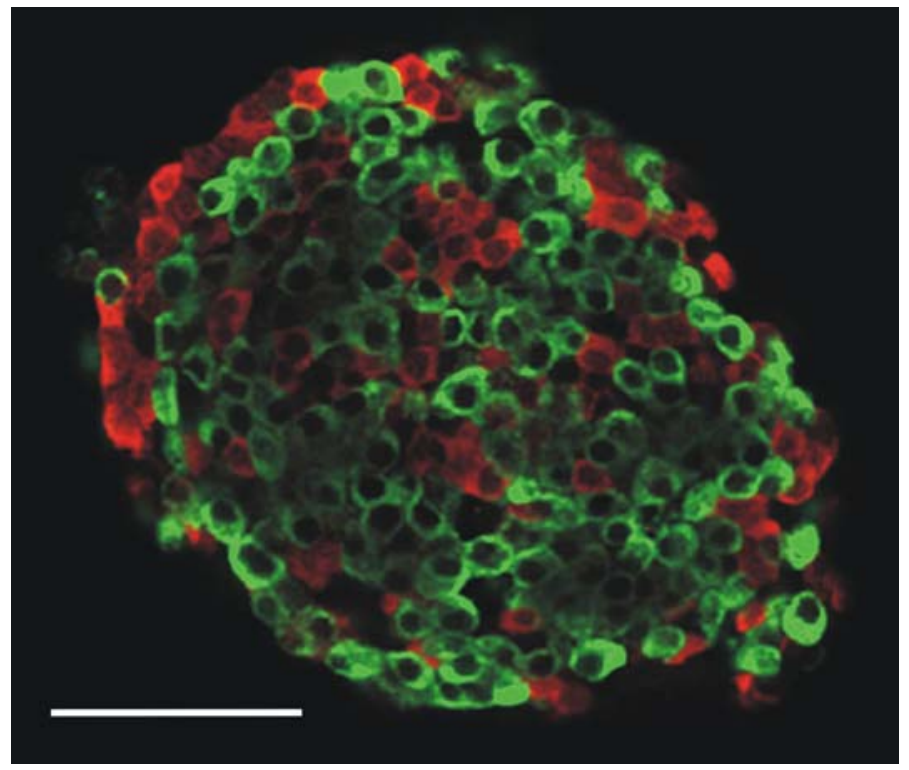

Figure 7: Islet microanatomy.

Confocal-based 3-D reconstruction of an immunostained islet. Cells are stained for insulin (green) and glucagon (red). Scale bar $50 \mu \mathrm{m}$. 


\subsection{Insulin secretion of $\beta$-cells in tissue slices}

\subsubsection{Insulin perfusion assay}

Several slices were combined to yield 25 to 30 islets and used to measure the insulin secretion from $\beta$-cells in a pancreatic tissue slice (Fig. 8). Insulin secretion stayed constant when incubated in extracellular solution containing $3 \mathrm{mM}$ glucose. After application of elevated glucose concentrations insulin secretion increased rapidly and dropped back to normal levels within 4 minutes. In contrast to this first phase of insulin secretion the second phase showed only a poor increase in insulin secretion.

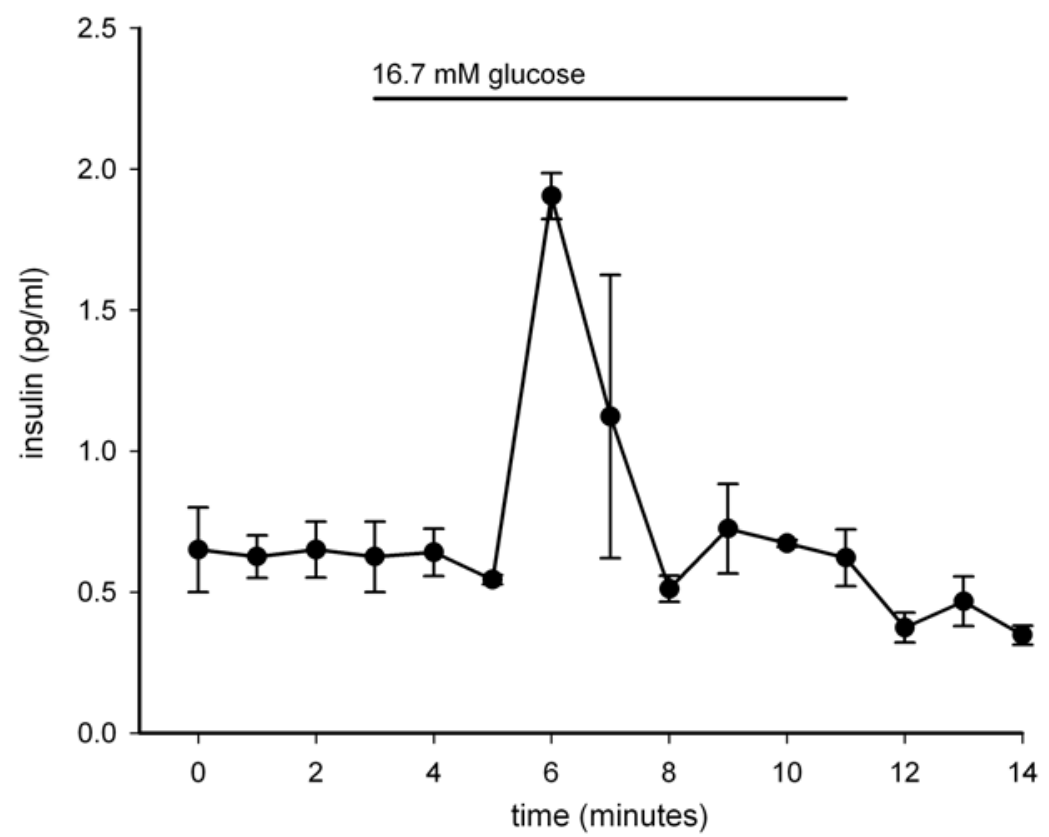

Figure 8: Insulin secretion of $\boldsymbol{\beta}$-cells

Released insulin from a pool of ten slices measured by ELISA. High glucose was applied as indicated. 


\subsubsection{Secretory activity of $\beta$-cells in slices}

To study the secretory activity of the $\beta$-cells in our preparation we employed a voltage pulse protocol mimicking the spiking activity recorded from $\beta$-cells on exposure to an elevated glucose concentration (Ashcroft and Rorsman, 1989). This pulse protocol consisted of a train of 50 pulses from the resting membrane potential of $-70 \mathrm{mV}$ to +10 $\mathrm{mV}$ with a pulse duration of $100 \mathrm{~ms}$ at a frequency of $3.3 \mathrm{~Hz}$ (total duration $15 \mathrm{~s}$ ). During these pulses cell capacitance and changes in the intracellular $\mathrm{Ca}^{2+}$ concentration were measured simultaneously (Fig. 9). The resting capacitance of the cells was $6.96 \pm 0.1 \mathrm{pF}$ $(n=255)$, which is consistent with earlier results on isolated islets (Gopel et al., 1999).

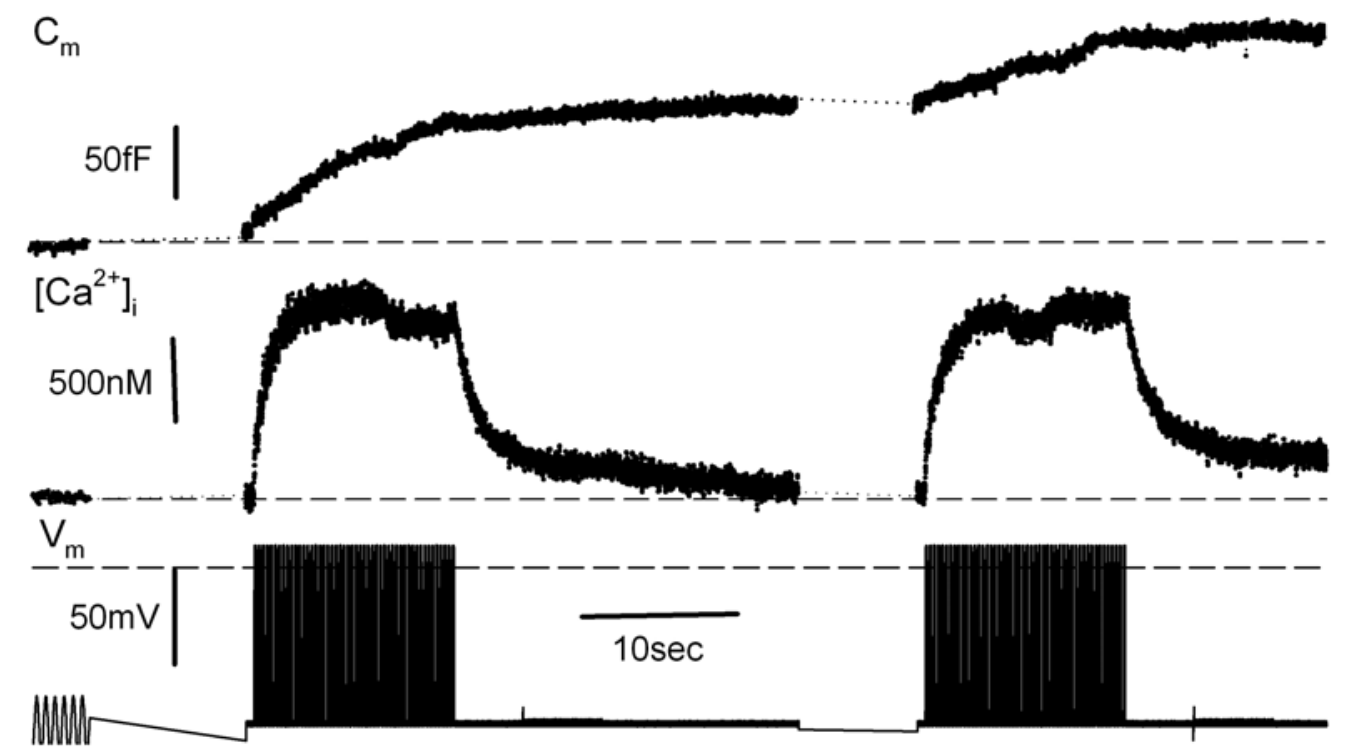

Figure 9: Secretory activity in $\beta$-cells of slices.

Typical secretory activity of $\beta$-cells in response to two successive trains of voltage pulses (lower trace). Upper trace: capacitance changes during voltage stimulation. Middle trace: change in cytosolic $\mathrm{Ca}^{2+}$ measured with Fura-6F.

Intracellular $\mathrm{Ca}^{2+}$ increased by $680 \pm 20 \mathrm{nM}(\mathrm{n}=4)$ during the voltage protocol. This change in the intracellular $\mathrm{Ca}^{2+}$ concentration change did not run down when applying a 
second depolarization train (Fig. 9). One-third of the cells studied did not react to the voltage protocol with a detectable capacitance change. The remaining two-thirds $(\mathrm{n}=22)$ responded with a mean capacitance change of $165 \pm 39 \mathrm{fF}$. With the second identical train of pulses after a 10 second interval the capacitance change was clearly reduced (111 $\pm 28 \mathrm{fF}$ ). As run-down of exocytosis occurs at a longer time scale, this so-called depression may be rather due to a lack of recycling, a process reported previously (Ammala et al., 1993).

\subsection{Electrical activity of $\beta$-cells in the pancreatic tissue slice}

A hallmark of the electrical activity of the $\beta$-cells is the hyperpolarized membrane potential at rest, followed by depolarization and spiking activity on exposure to elevated glucose concentrations (Dean and Matthews, 1968). The resting membrane potential depends primarily on the equilibrium potential for $\mathrm{K}^{+}$ions $\left(\mathrm{E}_{\mathrm{K}}\right)$ and values obtained using intracellular microelectrodes are close to the theoretical value of $\mathrm{E}_{\mathrm{K}}$ (Atwater et al., 1978). Similarly, under our experimental conditions with the extracellular solution containing $2.5 \mathrm{mM} \mathrm{K} \mathrm{K}^{+}$and the pipette solution containing low ATP, zero current potential was between -90 and $-100 \mathrm{mV}$. Additionally, resting membrane potential depended critically on the leak conductance, which we measured at $-110 \mathrm{mV}\left(\mathrm{E}_{\mathrm{K}}\right.$, no current through $\mathrm{K}^{+}$channels). To prevent falsified results because of elevated leak, cells with a resting membrane potential more positive than $-80 \mathrm{mV}$ and a leak conductance exceeding $2 \mathrm{nS}$ at basal conditions (about $25 \%$ ) were excluded from analysis. The standard pipette solution contained $2 \mathrm{mM}$ ATP, a concentration not sufficient to depolarize the membrane (Fig. 10). In fact, with $2 \mathrm{mM}$ ATP membrane potential 
sometimes remained at the initial level, but most often hyperpolarized for about $-5 \mathrm{mV}$ after a few minutes of whole-cell dialysis. This indicates that the resting ATP concentration in the murine $\beta$-cell probably exceeds $2 \mathrm{mM}$, as has been suggested previously (Ashcroft et al., 1973).

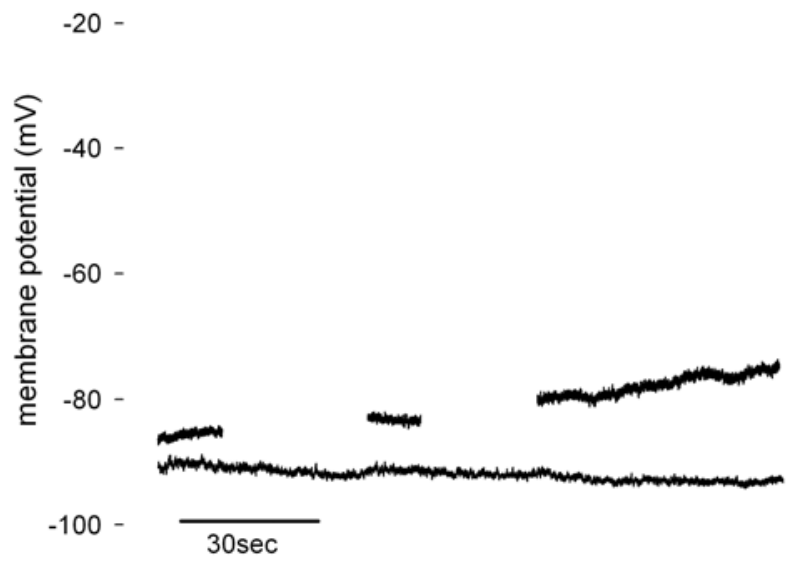

Figure 10: Membrane potential development during dialysis in $\beta$-cells. Representative traces of membrane potential change during the first 140 seconds in $\beta$-cells due to dialysis with $2 \mathrm{mM}$ (lower trace) and $5 \mathrm{mM}$ ATP (upper trace).

To take this into account $\beta$-cell properties were also studied with $5 \mathrm{mM}$ ATP in the pipette solution. Membrane potential measured directly after breaking the patch was found to be similar in experiments including 2 or $5 \mathrm{mM}$ ATP in the pipette, with $-90.6 \pm$ $1.0 \mathrm{mV}(\mathrm{n}=92)$ and $-91.1 \pm 1.6 \mathrm{mV}(\mathrm{n}=19)$, respectively. However, after dialysis the membrane potential was significantly changed in both conditions ( $p<0.005$ for $2 \mathrm{mM}$ ATP and $\mathrm{p}<0.0005$ for $5 \mathrm{mM}$ ATP). With $2 \mathrm{mM}$ ATP membrane potential hyperpolarized to $-94.1 \pm 0.8 \mathrm{mV}(\mathrm{n}=92)$, with $5 \mathrm{mM}$ ATP cells depolarized to $-74.1 \pm$ $3.6 \mathrm{mV}(\mathrm{n}=19)$ (Fig. 10). 
Superfusion of the slice with an elevated glucose concentration generally did not trigger electrical activity in cells dialyzed with 2 mM ATP (Fig. 11). Indeed, only $10 \%$ of patchclamped cells with $2 \mathrm{mM}$ ATP responded to glucose with supra-threshold depolarization and electrical activity. In some cells a slight depolarization of the membrane potential could be observed after the addition of high glucose, but this was far away from the threshold potential to induce electrical activity.

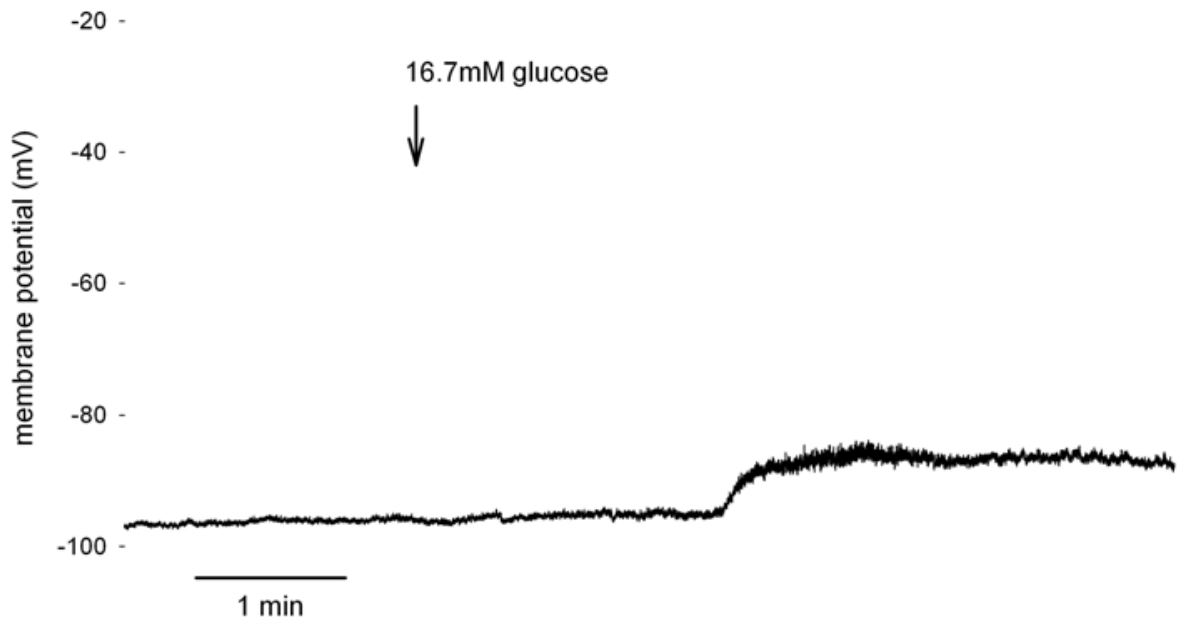

Figure 11: Electrical activity at $2 \mathrm{mM}$ ATP.

Membrane potential recording of a $\beta$-cell before and after application of elevated glucose levels, with $2 \mathrm{mM}$ ATP in the pipette solution.

In contrast to dialysis with $2 \mathrm{mM} \mathrm{ATP,} 5 \mathrm{mM}$ ATP inside the pipette made $\beta$-cells more ready to depolarize by exposure to glucose. All tested cells dialyzed with $5 \mathrm{mM}$ ATP depolarized after application of high glucose $(n=8)$ and this depolarization was associated with electrical activity, both sustained and intermittent (Fig. 12). The pattern of slow depolarization and action potentials was comparable to that observed with intracellular microelectrodes (see inset in Fig. 12 and (Dean and Matthews, 1970)). After 
removal of the elevated glucose concentration the membrane potential repolarized rapidly to values obtained before stimulus application.

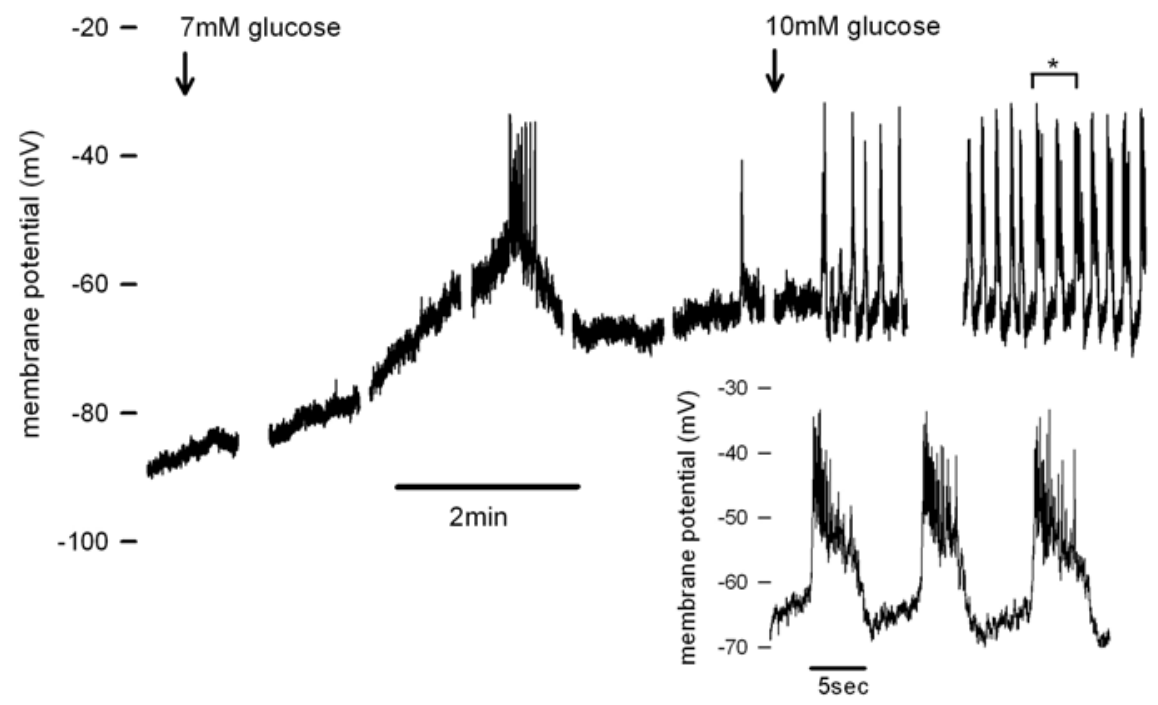

Figure 12: Electrical activity at $5 \mathrm{mM}$ ATP.

Membrane potential recording of a $\beta$-cell in response to the application of elevated glucose levels, with $5 \mathrm{mM}$ ATP in the pipette solution.

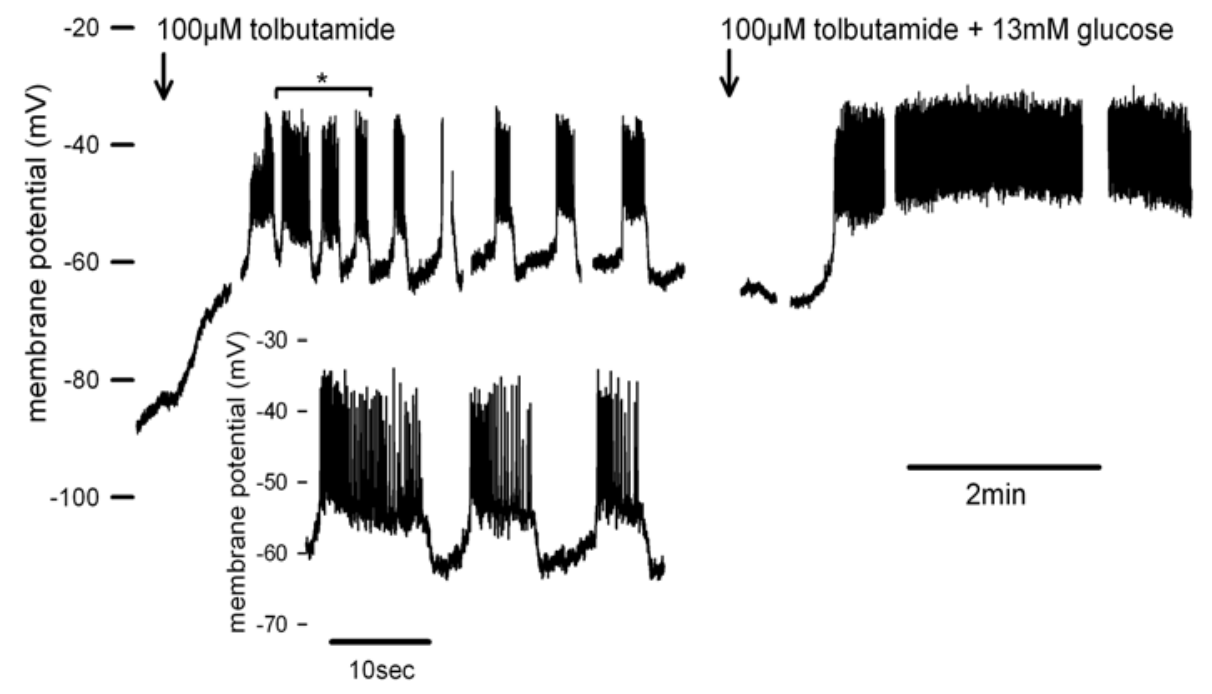

Figure 13: Electrical activity at $5 \mathrm{mM}$ ATP and tolbutamide.

Membrane potential recording of a $\beta$-cell in response to the application of $100 \mu \mathrm{M}$ tolbutamide and different glucose concentrations, with $5 \mathrm{mM}$ ATP in the pipette solution. 
The $\mathrm{K}_{\mathrm{ATP}}$ channel blocker and classical secretagogue tolbutamide depolarized the membrane potential rapidly in all tested cells independent of the ATP concentration applied intracellular (2 mM ATP: $\mathrm{n}=9 ; 5 \mathrm{mM}$ ATP: $\mathrm{n}=5$ ). Furthermore, in all cells with $5 \mathrm{mM}$ ATP this depolarization was associated with a bursting pattern at substimulatory glucose levels, and constant firing activity in the presence of elevated glucose levels (Fig. 13). With 2 mM ATP only $55 \%$ of the depolarized cells exhibited comparable electrical activity.

\section{4. $\quad K_{\mathrm{ATP}}$ channel conductance during electrical activity}

$\mathrm{K}_{\mathrm{ATP}}$ channels in $\beta$-cells link metabolism to membrane potential and therefore are of major importance for the stimulus-secretion coupling. The number of active $\mathrm{K}_{\mathrm{ATP}}$ channels is thought to determine the membrane potential of the $\beta$-cell and is responsible for the induction of electrical activity (Ashcroft and Rorsman, 1989). To measure the conductance of $\mathrm{K}_{\mathrm{ATP}}$ channels a voltage ramp was applied to the cell. The current between -100 and $-40 \mathrm{mV}$ flows through the weakly voltage-dependent, ATP- and tolbutamide-sensitive $\mathrm{K}_{\mathrm{ATP}}$ channels. At voltages exceeding $-30 \mathrm{mV}$ voltage-dependent delayed rectifying $\mathrm{K}^{+}$channels were activated (Ashcroft and Rorsman, 1989). The $\mathrm{K}_{\mathrm{ATP}}$ channel conductance was calculated from the slope of the current response between -100 and $-60 \mathrm{mV}$, basically representing the whole-cell conductance.

Figure 14 shows the conductance measured for $\beta$-cells after dialysis of $2 \mathrm{mM}$ (black bars) and $5 \mathrm{mM} \mathrm{ATP} \mathrm{(grey} \mathrm{bars)} \mathrm{and} \mathrm{after} \mathrm{the} \mathrm{additional} \mathrm{application} \mathrm{of} \mathrm{an} \mathrm{extracellular}$ stimulus. 


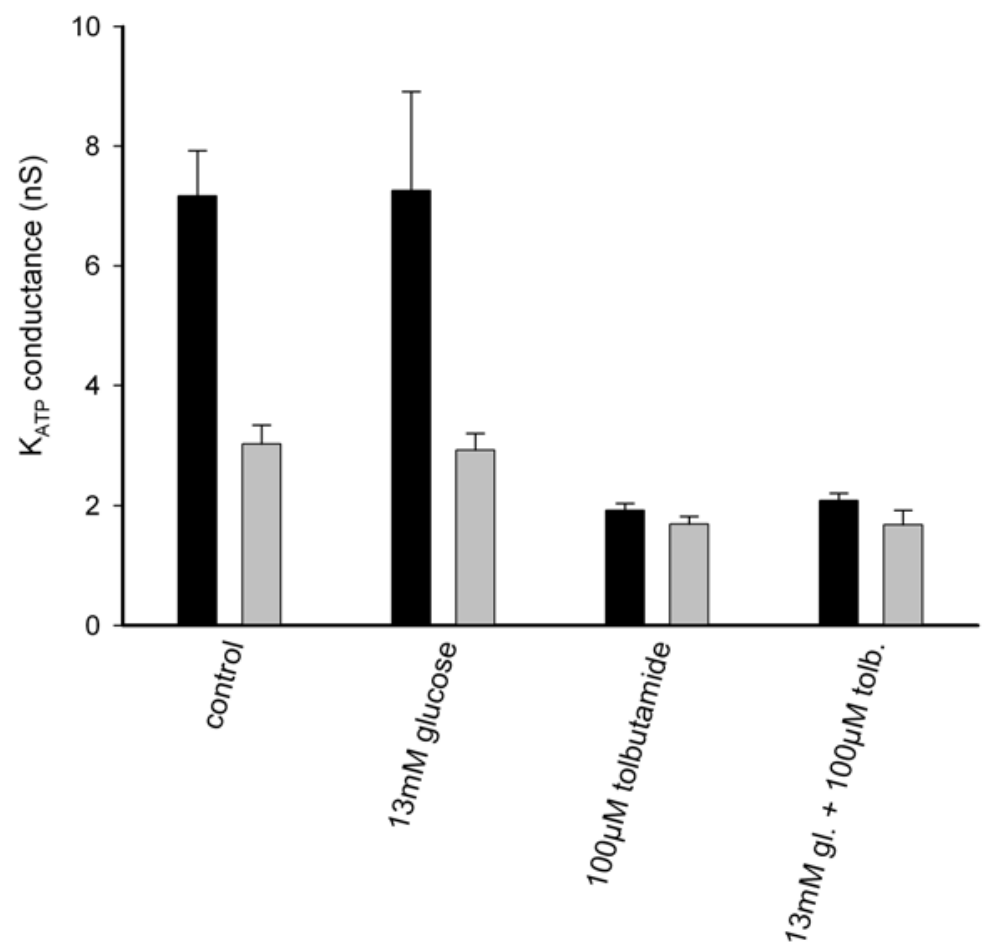

Figure 14: $\beta$-cell conductance after different intra- and extracellular applications.

$\mathrm{K}_{\text {ATP }}$ channel conductance after dialysis of intracellular $2 \mathrm{mM}$ (black bars) and $5 \mathrm{mM}$ ATP (grey bars) and after additional application of $13 \mathrm{mM}$ glucose, $100 \mu \mathrm{M}$ tolbutamide or both.

$\mathrm{K}_{\text {ATP }}$ channel conductance after dialysis of $2 \mathrm{mM}$ ATP was significantly $(\mathrm{p}<0.0005)$ higher compared to $5 \mathrm{mM}$ ATP, with $7.2 \pm 0.8 \mathrm{nS}(\mathrm{n}=23)$ and $3.0 \pm 0.3 \mathrm{nS}(\mathrm{n}=13)$, respectively. This corresponds to the observed difference in membrane potential due to dialysis (Fig. 11). Application of elevated glucose levels did not change the conductance significantly in both cases $(7.3 \pm 1.7 \mathrm{nS}$ with $2 \mathrm{mM}$ ATP $(\mathrm{n}=7)$ and $2.9 \pm 0.3 \mathrm{nS}$ with 5 mM ATP $(n=12))$. Apparently glucose was not able to change the intracellular ATP concentration clamped by the pipette solution. In $\beta$-cells dialyzed with $5 \mathrm{mM}$ ATP the superfusion of tolbutamide alone or together with high glucose was able to significantly $(\mathrm{p}<0.05)$ change the conductance, with 1.7. $\pm 0.1(\mathrm{n}=12)$ and $1.7 \pm 0.2(\mathrm{n}=5) \mathrm{nS}$, respectively. This indicates that not all channels were closed by intracellular application 
of $5 \mathrm{mM}$ ATP. Also the conductance measured after dialysis with $2 \mathrm{mM}$ ATP was significantly $(\mathrm{p}<0.0005)$ decreased by the application of tolbutamide to a value of $1.9 \pm$ $0.1 \mathrm{nS}(\mathrm{n}=8)$. The simultaneous application of high glucose and tolbutamide lowered the conductance in $\beta$-cells with $2 \mathrm{mM}$ ATP to the same extent as tolbutamide alone $(2.1 \pm 0.1$ $\mathrm{nS}(\mathrm{n}=9))$. The conductance measured after application of tolbutamide were comparable for cells dialyzed with 2 or $5 \mathrm{mM}$ ATP. Thus, as expected the inhibition of $\mathrm{K}_{\mathrm{ATP}}$ channels by tolbutamide did not depend on the intracellular ATP concentration of the cell.

\section{5. $\quad K_{\mathrm{ATP}}$ channel properties in $\beta$-cells in tissue slices and dispersed $\beta$-cells}

$\mathrm{K}_{\mathrm{ATP}}$ channels have been the subject of extensive studies and were described to differ in their properties depending on subtypes and preparation (Schwanstecher et al., 1992; Aguilar-Bryan and Bryan, 1999). To reveal existing differences of $\mathrm{K}_{\mathrm{ATP}}$ channel properties in the slice preparation, sensitivity of the channels to ATP was compared in tissue slices and dispersed cells.

Panels A and B of figure 15 show examples of current-voltage relations of $\beta$-cells dialyzed with different ATP concentrations or additionally exposed to the $\mathrm{K}_{\mathrm{ATP}}$ channel blocker tolbutamide. Cultured $\beta$-cells (Fig. 15 A) developed significantly lower $\mathrm{K}^{+}$ conductance at any given intracellular ATP concentration compared to $\beta$-cells in tissue slices (Fig. 15 B). 2 mM ATP completely inhibited $\mathrm{K}_{\text {ATP }}$ current of cultured cells as did the addition of extracellular applied $100 \mu \mathrm{M}$ tolbutamide (Fig. $15 \mathrm{~A}$ ). In $\beta$-cells of tissue slices $2 \mathrm{mM}$ ATP dialysis did not completely inhibit $\mathrm{K}_{\mathrm{ATP}}$ current and a reasonable fraction of $\mathrm{K}_{\mathrm{ATP}}$ channels remained active. Different from dispersed $\beta$-cells $100 \mu \mathrm{M}$ tolbutamide inhibited $\mathrm{K}_{\mathrm{ATP}}$ current in $\beta$-cells in tissue slices to a bigger extent than $2 \mathrm{mM}$ 
ATP (Fig. 15 B). However, in tissue slices $\beta$-cells retained a residual conductance even after application of high intracellular ATP levels and tolbutamide, which is in contrast to cultured cells. This residual conductance had a value of $1.7 \pm 0.1 \mathrm{nS}(\mathrm{n}=12)$. This conductance was already observed in studies on $\beta$-cells in isolated islets (Gopel et al., 1999) and was attributed to gap junctions coupling neighboring $\beta$-cells (Orci et al., 1973b). The value obtained in this study is somewhat higher than the gap junction conductance reported from studies on isolated islets (Gopel et al., 1999) and maybe due to the different preparations. Furthermore, $\beta$-cells patched in the present study were located in deeper layers of the islet probably coupled to more adjacent cells as the superficial $\beta$-cells studied in the experiments on isolated islets.

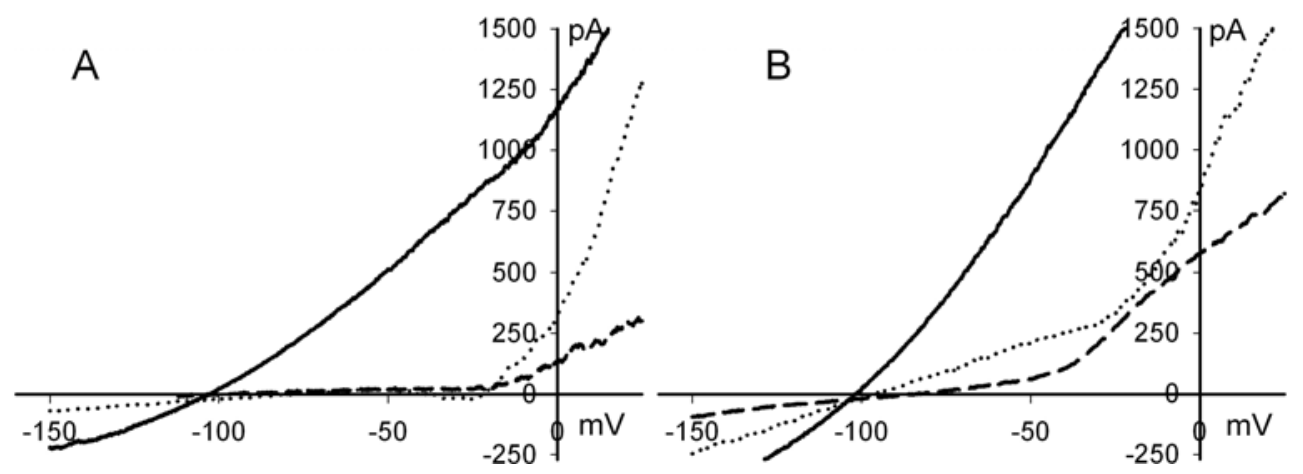

Figure 15: Whole-cell conductance in $\beta$-cells in slices and dispersed $\beta$-cells.

IV-plots of dispersed $\beta$-cells (A) and $\beta$-cells in tissue slices (B) after dialysis with 0 mM ATP (solid line), $2 \mathrm{mM}$ ATP (dotted line) and $2 \mathrm{mM}$ ATP plus $100 \mu \mathrm{M}$ tolbutamide (dashed line).

To isolate $\mathrm{K}_{\mathrm{ATP}}$ current for the analysis of $\mathrm{K}_{\mathrm{ATP}}$ channel properties the current at $-110 \mathrm{mV}$ was subtracted. The traces in figure $16 \mathrm{~A}$ and $\mathrm{B}$ display representative $\mathrm{K}_{\mathrm{ATP}}$ conductance development over a period of 4 minutes after membrane rupture in $\beta$-cells exposed to different intracellular ATP concentrations. Dialysis with $0 \mathrm{mM}$ ATP showed an obvious 
difference between the two preparations. In cultured cells conductance remained unchanged for more than one minute of dialysis and then increased slowly (Fig. 16 A). In tissue slices (Fig. 16 B) conductance increase appeared immediately with beginning of the whole-cell dialysis and developed clearly faster than in dispersed $\beta$-cells. Higher initial values were probably due to the time interval between membrane rupture and first applied voltage ramp. Maximal $\mathrm{K}_{\mathrm{ATP}}$ conductance recorded from $\beta$-cells in tissue slices and cultured $\beta$-cells exposed to $0 \mathrm{mM}$ ATP was $13.5 \pm 1.0 \mathrm{nS}(\mathrm{n}=15)$ and $9.9 \pm 1.8 \mathrm{nS}$ $(\mathrm{n}=8)$, respectively. At ATP concentrations lower than $\sim 1 \mathrm{mM}$ in dispersed $\beta$-cells and $\sim 2 \mathrm{mM}$ in slices, $\mathrm{K}_{\mathrm{ATP}}$ conductance transiently increased during the cytosol dialysis with the pipette solution. At higher ATP concentration much lower peak conductance was reached, conductance did not change or it decreased during dialysis.
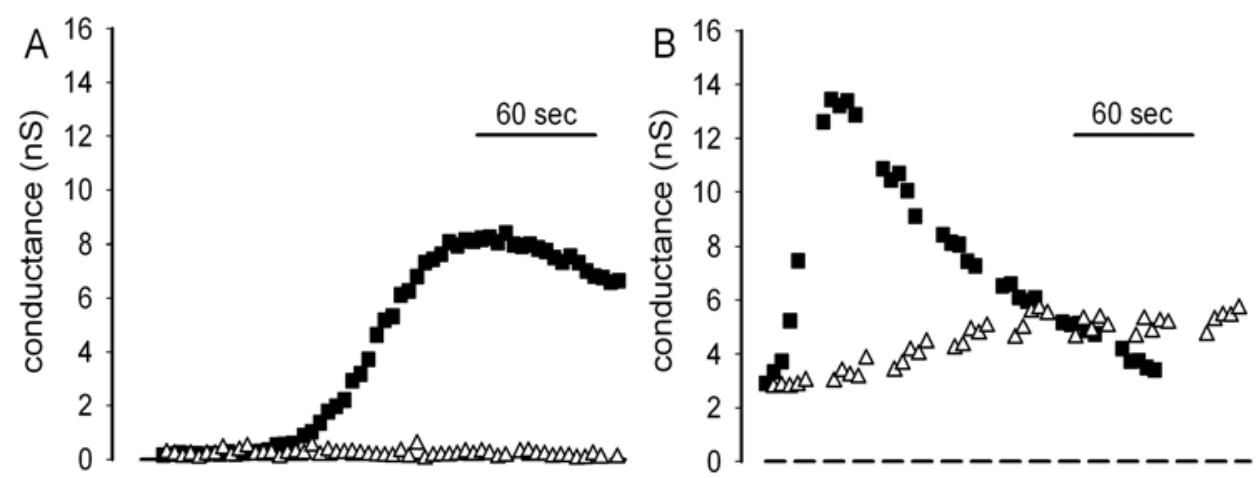

Figure 16: Conductance time-lapse in $\beta$-cells in slices and dispersed $\beta$-cells Development of conductance during dialysis with $0(\boldsymbol{\square})$ and $2(\Delta) \mathrm{mM}$ ATP in dispersed $\beta$ cells (A) and $\beta$-cells in tissue slices (B).

Cultured $\beta$-cells were found to be significantly bigger $\left(\mathrm{p}<10^{-7}\right)$ than $\beta$-cells in tissue slices, with $9.0 \pm 0.3 \mathrm{pF}(\mathrm{n}=80)$ compared to $6.9 \pm 0.1 \mathrm{pF}(\mathrm{n}=255)$. Out of this results a significantly different $(\mathrm{p}<0.005)$ current density of $2.0 \pm 0.2 \mathrm{nS} / \mathrm{pF}(\mathrm{n}=15)$ for $\beta$-cells 
in tissue slices and $0.9 \pm 0.3 \mathrm{nS} / \mathrm{pF}(\mathrm{n}=8)$ for cultured cells. This difference in channel density probably accounts for the observed difference in maximal conductance. $\mathrm{K}_{\mathrm{ATP}}$ peak conductance was assessed as a function of the intracellular ATP concentration in both preparations (Fig. 16, filled squares). For cells exhibiting no change in conductance at elevated ATP levels, we measured steady-state conductance at $300 \mathrm{sec}$ (Fig. 16, open triangles).

Figure 17 shows the dependence of $\mathrm{K}_{\mathrm{ATP}}$ channel activity on the intracellular applied ATP concentration in $\beta$-cells of pancreatic tissue slices in comparison to dispersed $\beta$ cells. To correct for the different $\mathrm{K}_{\mathrm{ATP}}$ densities in cultured cell and slice preparation values were normalized to the peak conductances at minimal ATP. The $\mathrm{IC}_{50}$ values obtained were $860 \mu \mathrm{M}(\mathrm{n}=5$ - 17) in slices compared to $370 \mu \mathrm{M}(\mathrm{n}=4-8)$ in dispersed cells.

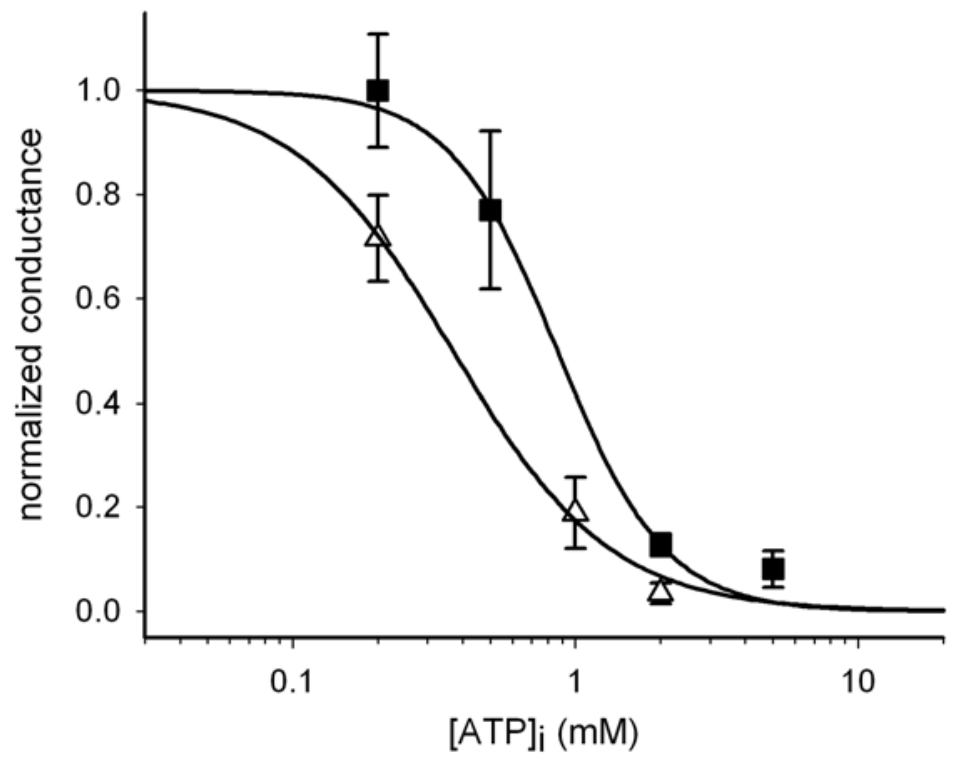

Figure 17: $K_{\mathrm{ATP}}$ channel inhibition by ATP

ATP dependent activity of $K_{\text {ATP }}$ channels in dispersed $\beta$-cells $(\Delta)$ and $\beta$-cells in slices ( $\left.\boldsymbol{\square}\right)$ normalized to maximal conductance. 
Diffusion exchange for dialysis of adrenal chromaffin cells through a patch-pipette predicts that the time constant for ATP molecule exchange is about 40 seconds (Pusch and Neher, 1988). Recording dialysis of Fura-2 confirmed the time constant for $\beta$-cells to be similar. Hence, the intracellular ATP is fully clamped to the pipette ATP concentration after $2-3$ min of whole-cell dialysis. As shown in figure 16 the peak conductance in $\beta$ cells in slices develops clearly before this time point in contrast to the conductance in cultured $\beta$-cells. This already indicated a difference in sensitivity to ATP, but also probably led to an underestimation of the $\mathrm{IC}_{50}$ for the slice preparation, when assessing the peak conductance as a function of the intracellular ATP concentration.

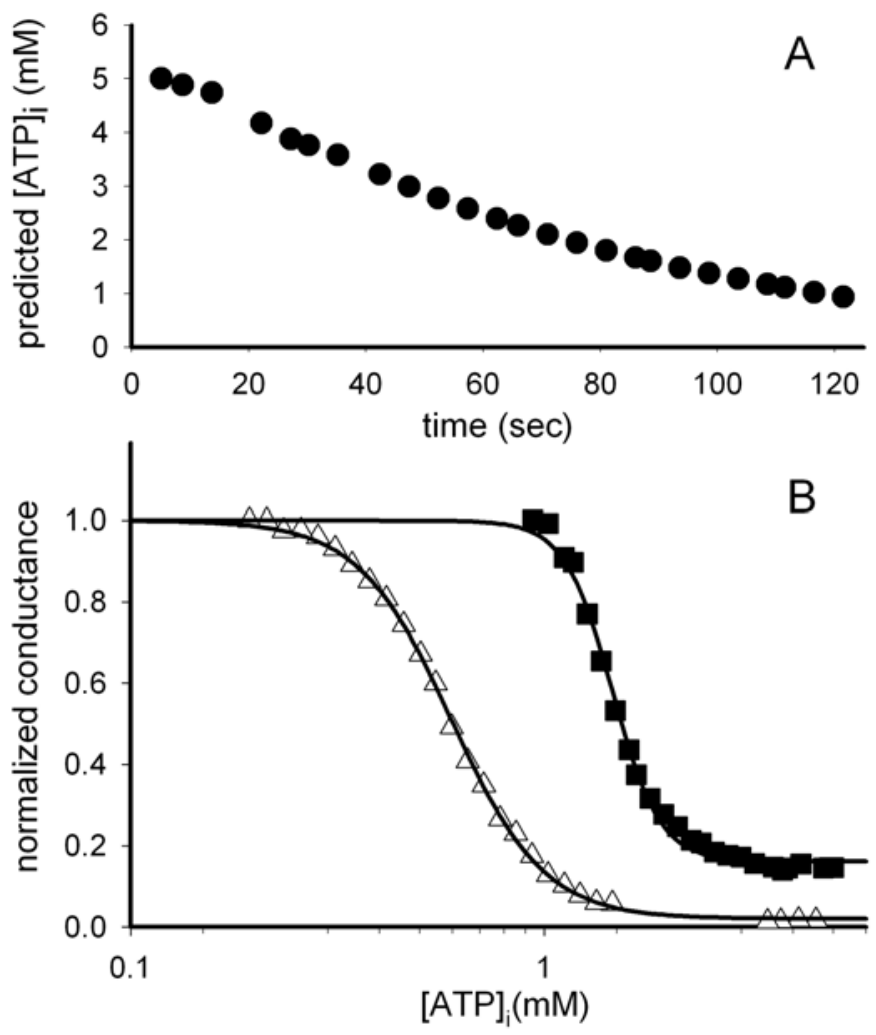

Figure 18: Calculated concentration dependence of $K_{\mathrm{ATP}}$ channel inhibition by ATP. (A) Calculated time profile of $[\mathrm{ATP}]_{\mathrm{i}}$ change during whole-cell dialysis. (B) Normalized conductance is plotted against the calculated ATP concentration for a representative $\beta$-cell in a tissue slice ( $\mathbf{\square})$ and a cultured $\beta$-cell $(\Delta)$. 
Assuming the initial intracellular ATP concentration to be $5 \mathrm{mM}$ the time-dependent ATP concentration change due to dialysis of a pipette solution containing $0 \mathrm{mM}$ ATP was calculated (cell size $6 \mathrm{pF}$ and $\mathrm{R}_{\mathrm{a}} 5 \mathrm{M} \Omega$; Fig. $18 \mathrm{~A}$ ). Figure 18 panel B shows the $\mathrm{K}_{\mathrm{ATP}}$ conductance plotted against the predicted cytosolic ATP concentration change for a cultured $\beta$-cell and a $\beta$-cell in slice at comparable dialysis conditions. As expected the $\mathrm{IC}_{50}$ obtained for cultured cells with $560 \mu \mathrm{M} \pm 0.07(\mathrm{n}=15)$ did not differ significantly from the peak conductance estimate and was still clearly below physiological ATP concentrations. In $\beta$-cells in slices, however, the $\mathrm{IC}_{50}$ of $1.43 \mathrm{mM} \pm 0.23 \mathrm{ATP}(\mathrm{n}=12)$ was higher as calculated before from the peak conductance and therefore shifted into a range to enable channel activity at physiological ATP levels.

$\mathrm{K}_{\mathrm{ATP}}$ conductance in the experiments of this study was observed to run down depending on the preparation and intracellular applied ATP. Studies on single $\mathrm{K}_{\mathrm{ATP}}$ channels have also reported decay of channel activity upon patch excision into ATP-free solutions (Ribalet et al., 2000). To study if also the characteristics of channel run-down are altered in the slice preparation, the course of $\mathrm{K}_{\mathrm{ATP}}$ conductance at different intracellular ATP concentration in $\beta$-cells of slices and cultured cells was compared. As an increase of intracellular $\mathrm{Ca}^{2+}$ accelerates run-down of $\mathrm{K}_{\text {ATP }}$ channels (Findlay, 1988) and $\mathrm{Ca}^{2+}$ is routinely used to induce run-down in reactivation studies (Ribalet et al., 2000), $\mathrm{K}_{\mathrm{ATP}}$ channel run-down at different $\mathrm{Ca}^{2+}$ buffering conditions was also studied. High $\mathrm{Ca}^{2+}$ buffering was achieved with $5 \mathrm{mM}$ EGTA and low buffering with $50 \mu \mathrm{M}$ EGTA. The measured resting cytosolic $\mathrm{Ca}^{2+}$ concentrations were $<10 \mathrm{nM}$ and $250-300 \mathrm{nM}$ at high and low buffering, respectively. Varying intracellular $\mathrm{Ca}^{2+}$ buffering capacity did not alter the onset of conductance increase or the maximum peak conductance. 
Figure 19 A displays two representative traces of $\mathrm{K}_{\mathrm{ATP}}$ conductance run-down in tissue slices and cultured $\beta$-cells at $0 \mathrm{mM} \mathrm{ATP.} \mathrm{The} \mathrm{channel} \mathrm{run-down} \mathrm{depended} \mathrm{significantly}$ on the preparation and on $\mathrm{Ca}^{2+}$ buffering conditions (Fig. $19 \mathrm{~B}$ ).
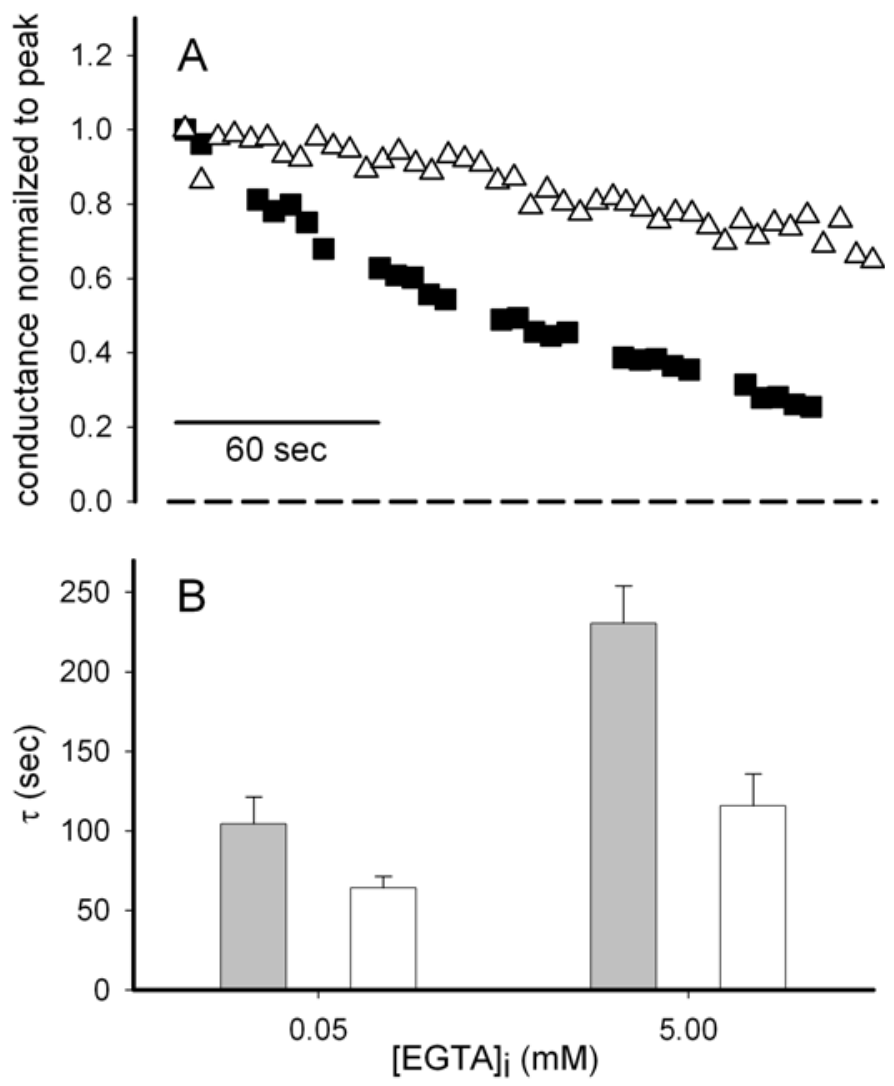

Figure 19: Run-down characteristics of $K_{\mathrm{ATP}}$ channel activity.

Representative traces of the conductance decay of $\beta$-cells in tissue slices ( $\mathbf{-})$ and cultured cells $(\Delta)$ exposed to $0 \mathrm{mM}$ ATP in $5 \mathrm{mM}$ EGTA. (B) Run-down time constant $\tau$ in cultured $\beta$-cells (grey bars) and $\beta$-cells in tissue slices (white bars) and its dependence on the $[\mathrm{EGTA}]_{\mathrm{i}}$.

Under the same conditions $\mathrm{K}_{\mathrm{ATP}}$ conductance decay in cultured $\beta$-cells was significantly slower compared to slices. Calculated values for $\tau$ at $50 \mu \mathrm{M}$ EGTA and $0 \mathrm{mM} \mathrm{ATP}$ were $64.3 \pm 7.1 \mathrm{sec}(\mathrm{n}=11)$ in tissue slices and $106.0 \pm 15.6 \mathrm{sec}(\mathrm{n}$ $=12)$ in cultured cells $(\mathrm{p}<0.05)$. With the pipette solution containing $5 \mathrm{mM}$ EGTA 
and $0 \mathrm{mM}$ ATP time constants of $115.7 \pm 29.3 \mathrm{sec}(\mathrm{n}=14)$ in tissue slices and $230.3 \pm 23.6 \mathrm{sec}(\mathrm{n}=10)$ in cultured cells were obtained $(\mathrm{p}<0.005)$. Differences due to the EGTA concentration within preparation were also significant $(\mathrm{p}<0.0005$ for dispersed cells and $\mathrm{p}<0.05$ for slices).

$\mathrm{K}_{\mathrm{ATP}}$ channel run-down in $\beta$-cells of tissue slices at fixed EGTA concentrations was dependent on the applied ATP concentration (Fig. 20). At 5 mM EGTA $\tau$ in the presence of $0.5 \mathrm{mM}$ ATP was $207.7 \pm 16.8 \mathrm{sec}(\mathrm{n}=7)$, significantly higher compared to $0 \mathrm{mM}$ ATP $(\mathrm{p}<0.01)$. In a pipette solution containing $50 \mu \mathrm{M}$ EGTA and $0.5 \mathrm{mM}$ ATP a $\tau$ value of $126.1 \pm 23.4 \mathrm{sec}(\mathrm{n}=11)$ was obtained, two-fold higher than at $0 \mathrm{mM} \mathrm{ATP}(\mathrm{p}<0.05)$.

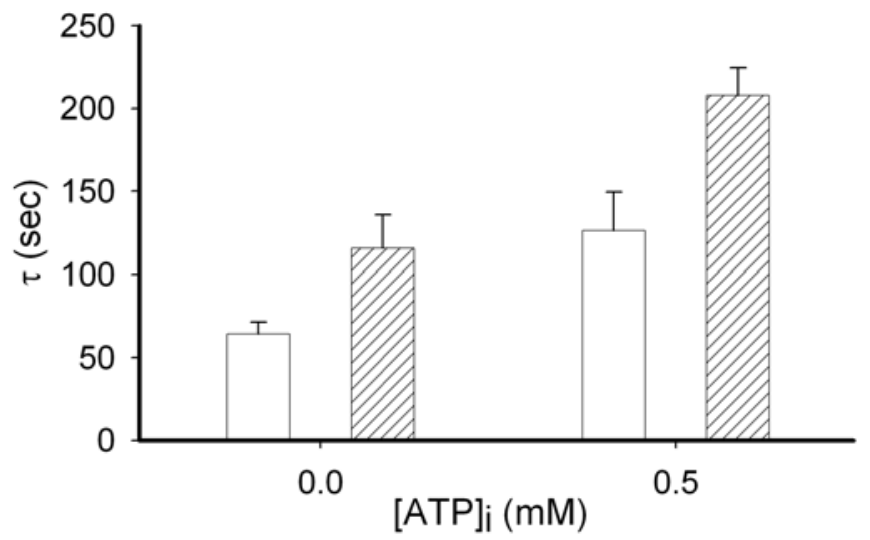

Figure 20: Effect of ATP on $K_{\text {ATP }}$ channel run-down.

Run-down time constant $\tau$ in $\beta$-cells in tissue slices at different ATP concentrations in the presence of $50 \mu \mathrm{M}$ (white bars) or $5 \mathrm{mM}$ EGTA (hatched bars). 


\subsection{Gap junction channel contribution to electrical activity}

The study on $\mathrm{K}_{\mathrm{ATP}}$ channel properties revealed the presence of gap junctions in the $\beta$ cells of tissue slices. As gap junctions enable electrical coupling, the effect on $\beta$-cell electrical activity was elaborated by experiments on connexin36-deficient mice (Guldenagel et al., 2001). In contrast to their wild type (+/+) and heterozygous (+/-) littermates connexin36 knock-out homozygous mice (Cx36 -/-) no longer express connexin36 and lack gap junction plaques and dye transfer between $\beta$-cells (Meda, personal communication). To confirm the absence of gap junctions we measured the residual conductance after application of $100 \mu \mathrm{M}$ extracellular tolbutamide together with $5 \mathrm{mM}$ ATP in the pipette solution (Fig. 21). Wild type Cx36 mice (+/+) and their heterozygous littermates $(\mathrm{Cx} 36+/-)$ showed a residual conductance of $1.4 \pm 0.1 \mathrm{nS}$ and $1.3 \pm 0.1 \mathrm{nS}$, respectively. In contrast, homozygous Cx36 knock-out mice (-/-) exhibited a significantly lower conductance of $0.2 \pm 0.07 \mathrm{nS}$.

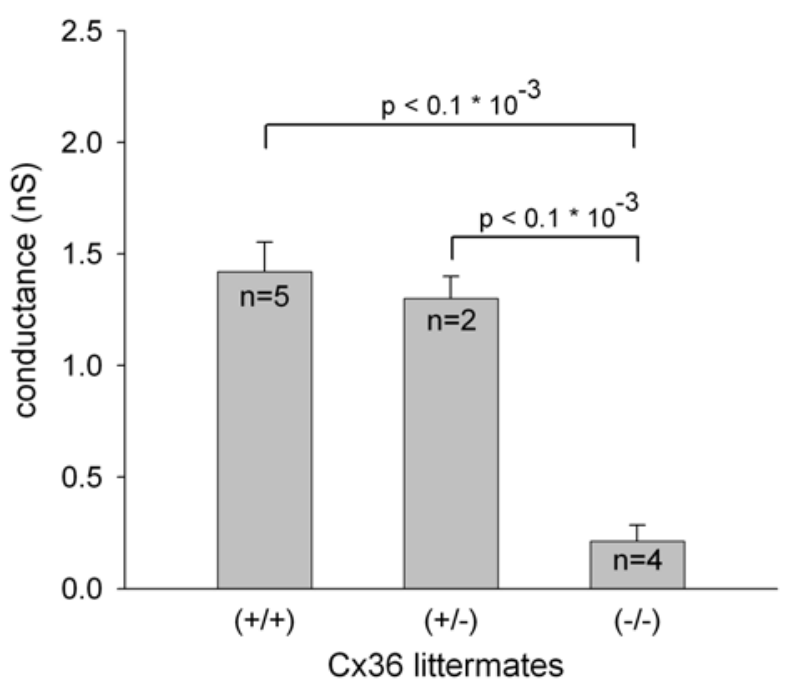

Figure 21: Residual conductance in $\beta$-cells of $\mathrm{Cx} 36$ littermates Conductance was measured after dialysis of $5 \mathrm{mM}$ ATP and application of $100 \mu \mathrm{M}$ tolbutamide. 
Residual conductance in connexin36 wild type mice was comparable to the value measured in NMRI mice. In $\beta$-cells of Cx36 (+/-) mice conductance after closure of $\mathrm{K}_{\mathrm{ATP}}$ channels was slightly, but not significant reduced. The small conductance remaining in Cx36 (-/-) indicates the lack of connexin36 expression and is probably due to technical leak.

After approving the absence of gap junction channels enabling electrical coupling we studied electrical activity in Cx36 littermates.

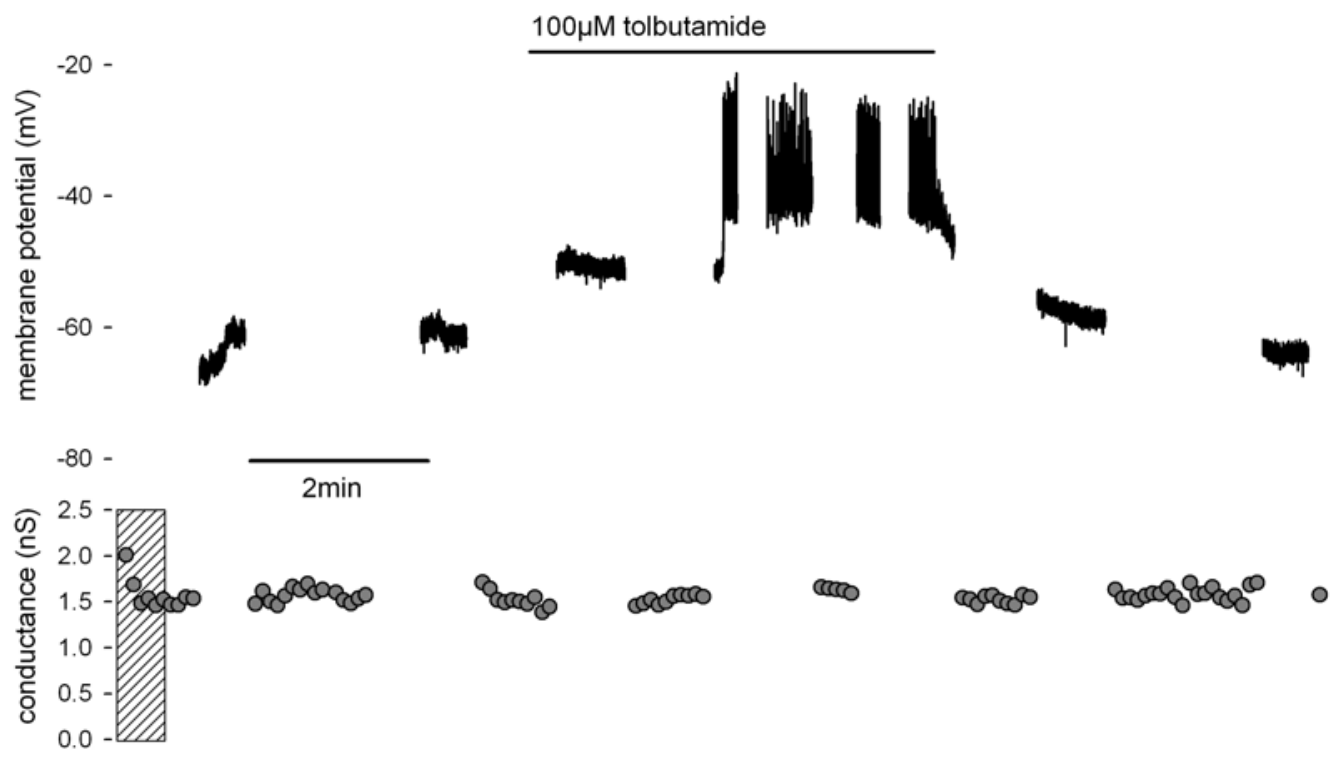

Figure 22: Electrical activity in $\beta$-cells of $\mathbf{C x 3 6}(+/+)$ mice

Membrane potential (upper trace) and $\mathrm{K}_{\mathrm{ATP}}$ channel conductance (lower trace) recorded from a $\beta$-cell of a Cx36 (+/+) mouse with $5 \mathrm{mM} \mathrm{ATP} \mathrm{in} \mathrm{the} \mathrm{pipette} \mathrm{solution} \mathrm{and} \mathrm{extracellular}$ application of $100 \mu \mathrm{M}$ tolbutamide as indicated.

As expected, it was necessary to supply a sufficient amount of ATP with the pipette solution to induce electrical activity by high glucose or tolbutamide in wild type Cx36 $(+/+)$ mice. The upper trace of Figure 22 shows a typical membrane potential recording 
from $\beta$-cells of a Cx36 (+/+) littermate. Due to dialysis of $5 \mathrm{mM}$ ATP from the pipette into the cell the membrane potential depolarized to $-68.25 \pm 11.0 \mathrm{mV}(\mathrm{n}=7)$. Thus, $\beta$ cells of Connexin36 mice were slightly more depolarized compared to wild type NMRI mice after dialysis of $5 \mathrm{mM}$ ATP (compare to Fig. 10). After dialysis the membrane potential remained constant in absence of any stimulus. Applying $100 \mu \mathrm{M}$ tolbutamide or $13 \mathrm{mM}$ glucose via the perfusion depolarized the membrane potential further and induced electrical activity in 5 out of 6 cells $(\sim 83 \%)$. Measuring whole-cell conductance simultaneously showed that $\mathrm{K}_{\mathrm{ATP}}$ channels closed due to dialysis of $5 \mathrm{mM}$ ATP within few tens of seconds to a constant value (Fig. 22, lower trace, hatched area). This residual conductance, $1.8 \pm 0.2 \mathrm{nS}(\mathrm{n}=7)$, was close to the obtained gap junction conductance for Cx36 (+/+) mice, indicating closure of most $\mathrm{K}_{\mathrm{ATP}}$ channels. Compared to NMRI mice, that showed a significant difference between application of $5 \mathrm{mM}$ ATP alone and addition of tolbutamide, $\mathrm{K}_{\mathrm{ATP}}$ channels in connexin36 mice were closed almost to the same extent by both treatments (see also Fig. 14). Thus, connexin36 mice appeared to be more sensitive to intracellular ATP application. After closure of $\mathrm{K}_{\mathrm{ATP}}$ channels the conductance remained unaltered for the rest of the experiments. Even during the application and wash-out of tolbutamide or high glucose, which was accompanied by electrical activity of the membrane potential, $\mathrm{K}_{\mathrm{ATP}}$ channel conductance did not change. Performing the same experiments on $\beta$-cells of heterozygous connexin 36 mice revealed identical properties in membrane potential and $\mathrm{K}_{\mathrm{ATP}}$ channel conductance recordings as in wild type mice (data not shown).

In Cx36 (-/-) mice $\mathrm{K}_{\mathrm{ATP}}$ channel conductance characteristics were similar as a result of dialysis of $5 \mathrm{mM}$ ATP (Fig. 23, lower trace). Conductance decreased rapidly and 
remained stable at a constant value. As in connexin $(+/+)$ and $(+/-)$ mice the conductance was not altered during the application of an extracellular stimulus. However, different from wild type mice, conductance in Cx36 (-/-) decreased to a value of $0.3 \pm 0.05 \mathrm{nS}(\mathrm{n}=$ 13). This again indicates the closure of the great majority of $\mathrm{K}_{\mathrm{ATP}}$ channels in response to $5 \mathrm{mM}$ ATP dialysis, as $\mathrm{K}_{\mathrm{ATP}}$ channel closure in $\beta$-cells lacking gap junctions only leaves over a small residual leak conductance.

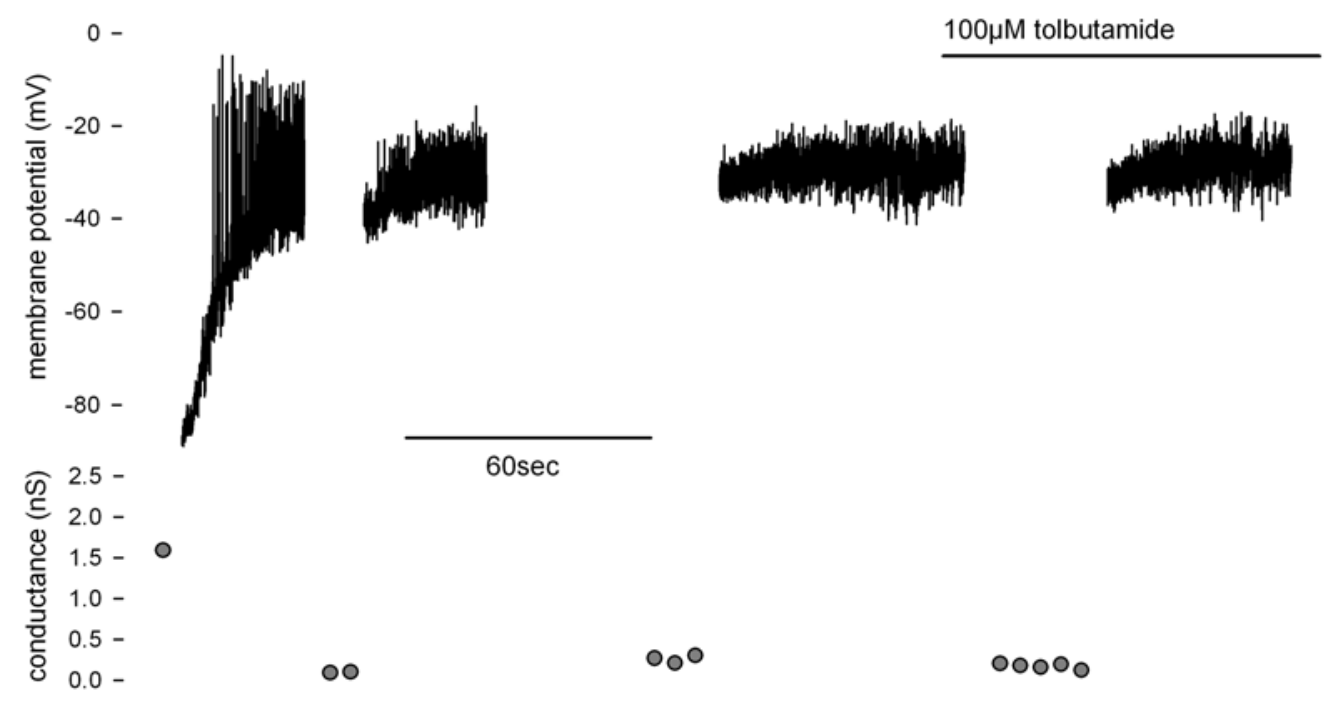

Figure 23: Electrical activity in $\beta$-cells of $\mathrm{Cx36}(-/-)$ mice

Membrane potential (upper trace) and $\mathrm{K}_{\mathrm{ATP}}$ channel conductance (lower trace) recorded from a $\beta$-cell of a Cx36 (-/-) mouse with $5 \mathrm{mM}$ ATP in the pipette solution and extracellular application of $100 \mu \mathrm{M}$ tolbutamide as indicated.

Of major difference was the observed change in membrane potential during dialysis of 5 mM ATP. The upper trace of figure 23 shows fast depolarization, after membrane rupture, followed by the initiation of electrical activity. The membrane potential of $\beta$ cells of $\mathrm{Cx} 36(-/-)$ mice depolarized to $-40 \pm 3.2 \mathrm{mV}(\mathrm{n}=6)$ after dialysis of $5 \mathrm{mM}$ ATP. 
This is significantly higher than the potential found in $\mathrm{Cx} 36(+/+)$ and corresponds to the threshold potential necessary to induce electrical activity.

To further reveal the contribution of electrical coupling, current changes in the patched cell during electrical activity were measured. In figure 24 current and membrane potential activity recorded from a $\beta$-cell of $\mathrm{Cx} 36(+/+)$ (right panel) and Cx36 (-/-) mice (left panel) are compared. Cx36 (-/-) showed no currents (lower trace) as clamping inhibits activity of the voltage dependent $\mathrm{Ca}^{2+}$ channels. In contrast, $\beta$-cells of $\mathrm{Cx} 36(+/+)$ mice showed current activity (lower trace) in voltage-clamp mode reflecting the recorded electrical activity (upper trace). This current probably originates from the electrical activity of neighboring cells and was also observed in perforated patch-clamp experiments on $\beta$-cells of isolated islets (Gopel et al., 1999).
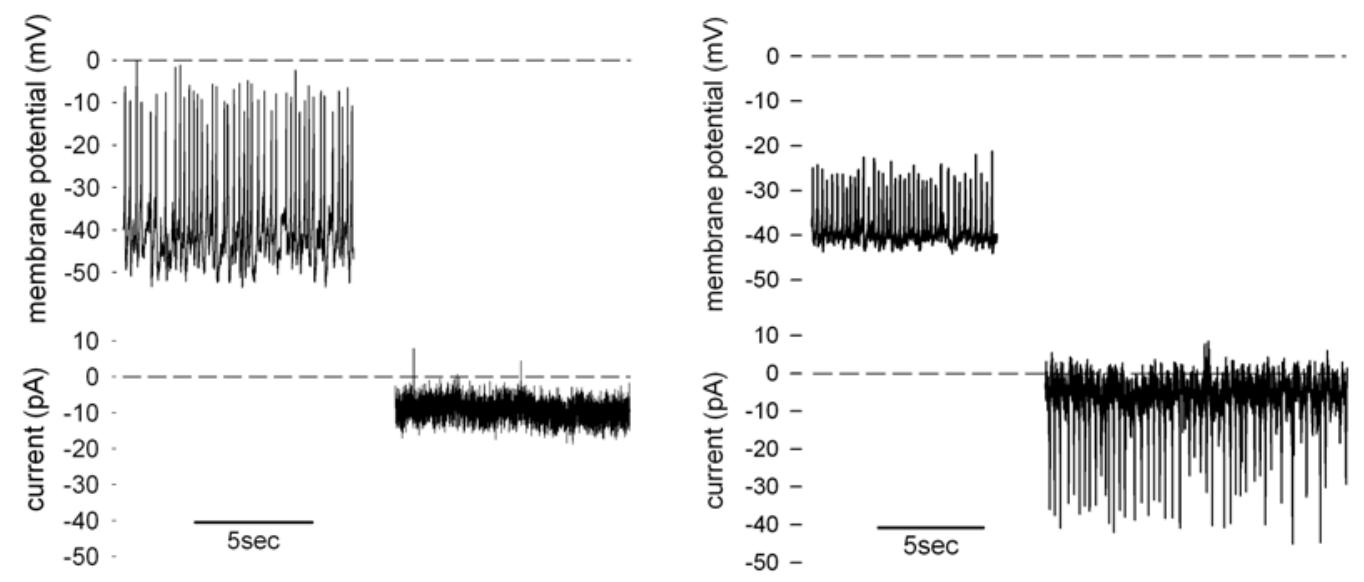

Figure24: Current injection in $\beta$-cells of $\mathrm{Cx36}$ littermates

Membrane potential (upper trace) and current (lower trace) recorded from $\beta$-cell of Cx36 (-/-) (left panel) and $\mathrm{Cx} 36(+/+)$ (right panel) littermates during electrical activity. 


\section{Discussion}

\subsection{Pancreatic tissue slices}

The slice technique has been used for several decades to study the function of various organs. Development of the acute pancreatic tissue slice preparation now also offers a new approach to study pancreatic cell function. As the pancreas consists of several different kinds of tissues pancreatic slices enable the study of various cell-types in one preparation. Acinar cells building up the exocrine tissue are the most frequent cells in a slice, but also endocrine, neuronal, endothelial, ductal and immune cells are present. Especially the endocrine cells situated in the islets of Langerhans are of major interest because of their role in blood glucose regulation. Studying the function of insulin secreting $\beta$-cells in tissue slices may help to understand some pathophysiological mechanisms underlying Diabetes mellitus, a severe and common disease.

Since more than 30 years dispersed single $\beta$-cells and isolated islets are the in vitro preparations of choice to study the characteristics of insulin secretion. In contrast to those preparations the study on tissue slices serves a number of advantages. Major differences in the preparation procedure make the slicing technique less invasive than the isolation of islets. In general, preparing pancreatic tissue slices is much faster and non-cooled periods are limited to a few minutes. The only chemical substance needed for slicing pancreas is agarose, which is known to be a non-toxic polysaccharide and is assumed not to affect cell function. Additionally, endocrine cells do not get into contact with the agarose as it is injected into the ductal system of the exocrine pancreas. Autolysis by exocrine enzymes 
released during slicing and later during the experiments does not appear to damage the endocrine cells. This probably can be ascribed to the large ratio of solution volume to released enzymes and the protective function of the islet capsule. Mechanical stress exerted on the tissue during the slice preparation procedure is limited to a minor number of superficial cells that have contact to the blade during slicing. More torsion or pressure for the endocrine cells is prevented by the stability of the slice, which is a consequence of the agarose inside the ductal system and surrounding the tissue. Isolating islets of Langerhans from the pancreas by the commonly used protocol is associated with a much higher amount of stress for the endocrine cells. Digestion of the exocrine tissue by exposure to enzymes like collagenase for tens of minutes at temperatures about $37{ }^{\circ} \mathrm{C}$ is likely to affect not only the exocrine tissue but also the islet of Langerhans. In contrast to islets in tissue slices, isolated islets lack a solid capsule enclosing the endocrine cells. This indicates that the digestion procedure has negative effects on the structures of islets, presumably influencing its function. One study supporting this assumption compared hormone secretion of islets isolated by microdisection to islets isolated by digestion with collagenase (Bodziony and Schwille, 1989). It revealed that basal insulin and glucagon secretion were increased in islets isolated by collagenase digestion and that these islets showed non-responsiveness of $\alpha$-cells to elevated glucose levels. Another report suggested the collagenase isolation technique to cause a loss of membrane receptors in the plasma membrane, leading to a decreased sensitivity towards insulin secretion modulators (Norfleet et al., 1975). Furthermore it was reported that the separation of islets, following the digestion, can also affect islet function. Transplanted islets enriched by the density gradient procedure, using the commonly employed substance Ficoll, were 
found to restore normoglycemia significantly slower than islets separated by filtration (Salvalaggio et al., 2002).

However, not only the possible damage due to chemical or mechanical stress is a disadvantage of the isolated islet preparation. Limitations of the separation procedure considering the morphology of isolated islets may prevent to obtain representative results. Islets gained from both preparations vary in size, but in contrast to isolated islets about 50 $\%$ of the islets found in tissue slices are not simply round but of a more complex structure. This includes islets of ellipsoid shape, islets surrounding vessels or ducts and islets with a less dense core. Importance of this dissimilarity in preparations arises from the finding that morphology variations seem to be of physiological relevance. Sizerelated differences in the glucose sensitivity and amplitude of insulin secretion have been observed in isolated islets (Aizawa et al., 2001). Apparently isolating islets by digestion and gradient separation largely sorts for densely packed round islets and disregards islets of other shapes. As a consequence pools of isolated islets do not reflect the actual status of the pancreas and islets with a certain kind of physiological properties may not be included. Additionally, islets from diverse parts of the pancreas where reported to differ in islet function due to changes in the relative proportion of endocrine cells (Trimble et al., 1982). Further studies will have to reveal if also the specific location inside an acinar branch of the pancreas or the association to vessels, ducts or other islets reflects differences in islet hormone secretion. To reveal these questions the tissue slice preparation is a highly suitable system.

Beside the slicing procedure, main advantages of pancreatic tissue slices are based on the morphological properties of the preparation. Only the outer cell-layers in a slice are 
disrupted from their natural environment providing conditions highly reminiscent to the in vivo situation for the major portion of the tissue. Furthermore, tissue slices maintain the gross anatomy of the organ. From this follows that cells in the inner layers of the slice are surrounded by adjacent cells as in the intact organ and keep their complex system of cell-to-cell interactions. Additionally the pancreatic tissue slice preparation preserves the innervation of islets as fibres and ganglia are present (see Fig. 5). Maintenance of these structures under physiological conditions enables them to exhibit influence on $\beta$-cell function. Modulation of $\beta$-cell activity by many different factors has been reported to be of major impact for a proper homeostasis of blood glucose (Weir and Bonner-Weir, 1990; Fehmann et al., 1995; Sharp, 1996; Ahren, 2000; Henquin et al., 2003). The presence of insulin secretion modulation in tissue slice has to be revealed by further studies. However, it is probable that the conserved environment for islets has profound influence on its function.

More advantages of the tissue slices arise from the applicability of the preparation. Pancreatic tissue slices are obtained easily and rapidly. The available number of islets gained by slicing from one pancreas exceeds the corresponding value of the isolation procedure easily and this reduces animal use. Furthermore, tissue slices can be prepared independently from the age or size of the animal. This allows to study islet-cell function not only in adult but also in embryonic and post natal mice. Thus, in combination with organotypic cultures of slices emphasis can be put on the elaboration of secretion development (Meneghel-Rozzo et al., 2004). Additionally, the use of pancreatic tissue slices makes it possible to study endocrine cell function in transgenic animal models. Mutant mice that do not survive birth or die at a very young age, e.g. Pax4 knock-out, 
(Sosa-Pineda et al., 1997) can now be studied by the use of tissue slices. In other mutant mice, e.g. Pax6 knock-out, endocrine cells are not able to form distinct islets (St-Onge et al., 1997), limiting the application of the isolation procedure and thereby averting the study of cell-function. Also this can now be done by using the slicing technique. Finally, to perform patch-clamp experiments on $\beta$-cells in deeper layers of islets is an advantage of pancreatic tissue slices realized in the studies discussed here. In contrast, in isolated islets the application of the patch-clamp technique is limited to the surface cells (Gopel et al., 1999).

\section{2. $\quad \beta$-cell secretory activity in slices}

Glucose induced insulin secretion measured from a combination of several slices revealed the typical kinetics. Stimulated insulin release showed a large first phase and a second phase of flat shape and small amplitude. This corresponds to the pattern reported for mice in contrast to the kinetics in rats that shows a more pronounced second phase (Ma et al., 1995). Thus, tissue slices provide the possibility to perform insulin perfusion essays.

Mimicking the typical electrical activity of $\beta$-cells revealed one third of the cells not to respond with a capacitance change. It is likely that these cells may reflect a population of $\beta$-cells that is not able to secret insulin, as heterogeneity and unresponsiveness of $\beta$-cells are well known (Clark et al., 2001). The other two thirds of $\beta$-cells showed a change in capacitance corresponding to about 45 vesicles in 15 seconds, using a conversion factor of $3.5 \mathrm{fF}$ per granule (Kanno et al., 2004). This is a 10 fold higher secretion rate compared to the peak rate measured during first phase insulin secretion $(\sim 3$ vs. $\sim 0.3$ 
granules per second) (Bratanova-Tochkova et al., 2002). Part of the discrepancy may be due to unresponsive $\beta$-cells that falsify the calculation of the secretion rate from insulin release. From our experiments this accounts for one third of the cells. In addition it was shown that exocytosis is highly voltage dependent. Stimulus pulses from resting membrane potential to $+10 \mathrm{mV}$ induce a 5 -fold higher capacitance change than pulses to $20 \mathrm{mV}$, which is close to the peak of electrical activity action potentials (Gopel et al., 2004). Incorporating these factors into the calculations lowers the secretion rate to $\sim 0.25$ granules per second. Collectively, this points up that exocytosis measured by capacitance measurements in the slice preparation show comparable secretion rates to those determined by biochemical methods from perfused pancreas. This was not shown using any other preparation so far.

\section{3. $\quad K_{\mathrm{ATP}}$ channel properties in $\beta$-cells in tissue slices}

$\mathrm{K}_{\mathrm{ATP}}$ channels play a major role in sensing the blood glucose concentration to the rate of insulin secretion (Aguilar-Bryan and Bryan, 1999). Elaborating the properties of $\mathrm{K}_{\mathrm{ATP}}$ channels in $\beta$-cells in tissue slices showed important differences to $K_{\text {ATP }}$ channels in dispersed $\beta$-cells of the present study and in inside-out patches reported before. First, $\mathrm{K}_{\mathrm{ATP}}$ channel density in $\beta$-cells in tissue slices was almost double compared to dispersed $\beta$-cells. This is likely to be due to differences in the preparation procedure which may also be responsible for the observed difference in size of the $\beta$-cell. Secondly, $\mathrm{K}_{\mathrm{ATP}}$ channels in $\beta$-cells in tissue slices were found to be less sensitive to ATP than in any other preparation studied so far. Measurements of $\mathrm{K}_{\mathrm{ATP}}$ channel inhibition by ATP in excised patches obtained an $\mathrm{IC}_{50}$ of $15 \mu \mathrm{M}$ (Cook and Hales, 1984). The $\mathrm{IC}_{50}$ for 
dispersed $\beta$-cells determined in this study was clearly higher and similar to previously published data (Schwanstecher et al., 1992). In comparison to cultured $\beta$-cells and excised patch, ATP-dependence of $\mathrm{K}_{\mathrm{ATP}}$ channels in $\beta$-cells in tissue slices showed a clear shift to millimolar intracellular ATP concentration indicating reduced sensitivity of $\mathrm{K}_{\mathrm{ATP}}$ channels to ATP. Thus, the higher $\mathrm{IC}_{50}$ value in tissue slices eliminates the discrepancy between $\mathrm{IC}_{50}$ and measured cytosolic ATP levels (Niki et al., 1989) that existed up to date. This discrepancy made it impossible to link physiological ATP levels to $\mathrm{K}_{\mathrm{ATP}}$ channel activity. Even in cultured $\beta$-cells $\mathrm{K}_{\mathrm{ATP}}$ channels are already fully closed at $2 \mathrm{mM}$ ATP. In contrast, in $\beta$-cells in slices at $5 \mathrm{mM} \mathrm{ATP}$, which corresponds to measured physiological ATP levels (Ashcroft et al., 1973), more than $10 \%$ of $\mathrm{K}_{\mathrm{ATP}}$ channels are still open (Fig. 17). This is enough to maintain resting membrane potential and enables induction of depolarization with small elevations of intracellular ATP. Studies on the ATP sensitivity of $\mathrm{K}_{\mathrm{ATP}}$ channels to reveal the reasons for the observed discrepancy showed a dependence of the $\mathrm{IC}_{50}$ on the preparation. The $\mathrm{IC}_{50}$ value was found to increases the more physiological the conditions for $\mathrm{K}_{\mathrm{ATP}}$ channels in the studied preparation are (Schwanstecher et al., 1992). This corresponds to the observed increasing $\mathrm{IC}_{50}$ in different preparations in the order membrane patches, dispersed cells and slices. Several mechanisms responsible for the decrease in sensitivity have been discussed. One report suggested the amount of cytoplasm and ATP-consuming enzymes to increase in the different preparations and thereby modulating sensitivity (Schwanstecher et al., 1992). Today a number of cytosolic factors are known to decrease sensitivity of $K_{\text {ATP }}$ channels to ATP. Especially phosphatidylinositol phosphates (PIPs) (Baukrowitz et al., 1998; Shyng and Nichols, 1998) and long-chain acyl-coenzyme A (LC-CoA) esters 
(Branstrom et al., 1998; Gribble et al., 1998) have been object of numerous studies dealing with $\mathrm{K}_{\mathrm{ATP}}$ channel sensitivity. Both types of lipids have been found to reduce $\mathrm{K}_{\text {ATP }}$ channel inhibition by ATP, exerting their effect by the same mechanism (Schulze et al., 2003). Thus, concentration differences of cytosolic factors in various preparations may be the reason for different sensitivities to ATP. As another regulatory mechanism the $\mathrm{ATP} / \mathrm{ADP}$ ratio rather than the ATP concentration alone is thought to determine the activity of the $\mathrm{K}_{\mathrm{ATP}}$ channels. In this model higher levels of ADP are activating the channel, increasing the required ATP concentration for channel closure. (Dunne and Petersen, 1986; Misler et al., 1986). The clearly decreased sensitivity to ATP observed in the tissue slice preparation enables the modulation of $\mathrm{K}_{\mathrm{ATP}}$ channels by physiological ATP concentrations. It is likely that the presence of modulating factors like PIPs and LCCoA esters in higher concentrations are responsible for this phenomenon.

In this study $\mathrm{K}_{\mathrm{ATP}}$ channel sensitivity to ATP has also been shown to differ between certain mouse strains. NMRI mice were shown to keep a substantial amount of $\mathrm{K}_{\mathrm{ATP}}$ channels active after the intracellular application of $5 \mathrm{mM}$ ATP. Tolbutamide application was able to significantly lower whole-cell conductance. In connexin36 mice, which are based on $\mathrm{C} 57 \mathrm{Bl} / 6$ mice, dialysis of $5 \mathrm{mM}$ ATP lowered the conductance to a higher degree and closed approximately the same portion of $\mathrm{K}_{\mathrm{ATP}}$ channels as the additional application of tolbutamide. To clarify the physiological relevance for this sensitivity difference further studies are required.

Another deviance of $\mathrm{K}_{\mathrm{ATP}}$ channel properties in $\beta$-cells in tissue slices regards the properties of channel run-down. Gradual inactivation of $\mathrm{K}_{\mathrm{ATP}}$ channels with time was already recognized with their first description using the inside-out patch-clamp technique 
(Noma, 1983; Cook and Hales, 1984). This run-down was reported to be accelerated by an increase in the intracellular $\mathrm{Ca}^{2+}$ concentration in inside-out patches (Findlay, 1988). In this study in $\beta$-cells in tissue slices as well as in dispersed $\beta$-cells the same effect of $\mathrm{Ca}^{2+}$ was observed. $\mathrm{Ca}^{2+}$ is widely used for induction of run-down, but the mechanism is still a matter of debate. It was suggested that $\mathrm{Ca}^{2+}$-induced run-down is due to hydrolysis of $\mathrm{PIP}_{2}$ mediated by endogenous $\mathrm{Ca}^{2+}$-dependent PLC and/or electrostatic interaction between PIP $_{2}$ and the C-terminus of Kir6.2 (Hilgemann and Ball, 1996). Alternatively it was reported that $\mathrm{Ca}^{2+}$-induced run-down is an intrinsic feature of the Kir6.2 subunit (Tucker et al., 1997). However, Kir6.2 subunit expressed in absence of the SUR1 subunit is less sensitive to $\mathrm{Ca}^{2+}$ than in its presence (Xie et al., 1999). The present study does not reveal the mechanism for $\mathrm{Ca}^{2+}$-induced acceleration of run-down, but points out the presence of this $\mathrm{K}_{\mathrm{ATP}}$ channel property in the tissue slice preparation.

Another feature of $\mathrm{K}_{\mathrm{ATP}}$ channel run-down, observed in inside-out patches, is its dependence on ATP. Application of Mg-ATP to the cytosolic side was found to prevent or even restore run-down (Ohno-Shosaku et al., 1987), but despite extensive analysis, the mechanism required to maintain $\mathrm{K}_{\mathrm{ATP}}$ channel activity is still unclear. Attempts to explain this phenomena include phosphorylation / dephosphorylation reactions (Ashcroft, 1988), uncoupling of $K_{\text {ATP }}$ channels from the actin cytoskeleton (Furukawa et al., 1996) and hydrolysis of anionic phospholipids (Shyng and Nichols, 1998). Also $\mathrm{K}_{\mathrm{ATP}}$ channel run-down in $\beta$-cells in tissue slices was found to depend on the intracellular ATP level. Interestingly the ATP level to prevent run-down in tissue slices has been found to exceed $1 \mathrm{mM}$, clearly higher than in inside-out patches. Together with the above discussed data this reveals a generally decreased sensitivity of $\mathrm{K}_{\mathrm{ATP}}$ channels to ATP regarding the 
activating, as well as the inhibiting action of ATP. Experiments on homomeric Kir6.2 $\Delta$ C36 channels, which are able to express functional channels without the SUR1 subunit, reported both actions of ATP to be intrinsic for the Kir6.2 subunit (Tucker et al., 1997). Thus, it is possible that the same mechanisms responsible for the decreased inhibitory effect of ATP on $\mathrm{K}_{\mathrm{ATP}}$ channels also lower the activating effect of Mg-ATP. However, the SUR1 subunit was shown to modulate the properties of Kir6.2 to a great extent. On the one hand SUR1 exerts a hypersensitizing effect, increasing the sensitivity to ATP (Shyng et al., 1997) and on the other hand SUR1 is responsible for a fast component of run-down of $\mathrm{K}_{\mathrm{ATP}}$ channels (Ribalet et al., 2000). This proposes an altered modulatory effect of SUR1 on Kir6.2 to be responsible for the observed different $\mathrm{K}_{\mathrm{ATP}}$ channel properties in the tissue slice preparation. Probably one or both of these mechanisms is responsible for the difference in channel run-down of $\mathrm{K}_{\mathrm{ATP}}$ channels observed between dispersed $\beta$-cells and tissue slices.

The described method to determine the sensitivity of $K_{\text {ATP }}$ channels in whole cell conditions should enable us to test the assumption that reduced ATP-sensitivity is capable in inducing insufficient insulin release and diabetes mellitus (Koster et al., 2000).

\subsection{Contribution of gap junctions to electrical activity of $\beta$-cells in tissue slices}

Provided that sufficient intracellular ATP was applied, the electrical activity recorded from $\beta$-cells in tissue slices followed the typical pattern. Glucose generated regular bursting with the length of the active phases depending on the glucose concentration. Tolbutamide also induced a bursting pattern and application of tolbutamide plus high glucose rendered bursting into a constant firing activity. Finally, the addition of the $\mathrm{K}_{\mathrm{ATP}}$ 
channel opener diazioxide was able to hyperpolarize the membrane potential after the induction of a depolarization. Thus, electrical activity recorded from a $\beta$-cell in a pancreatic tissue slice shows the same properties as reported for intracellular microelectrodes (Dean and Matthews, 1968) and perforated patch experiments (Gopel et al., 1999).

However, to detect electrical activity in our conditions it was necessary to include a sufficient amount of ATP in the pipette solution. Addition of $2 \mathrm{mM}$ ATP to the intracellular solution showed no depolarization of the membrane potential, even several minutes after membrane rupture. Including $5 \mathrm{mM}$ ATP in the intracellular solution depolarized the membrane slightly. This membrane potential behavior can be explained by the corresponding $\mathrm{K}_{\mathrm{ATP}}$ channel activity. $2 \mathrm{mM}$ ATP applied intracellular is lower than physiological levels and enables the opening of more $\mathrm{K}_{\mathrm{ATP}}$ channels. In contrast, dialysis of $5 \mathrm{mM}$ ATP closed a significantly higher number $\mathrm{K}_{\mathrm{ATP}}$ channels leading to the observed depolarization. During superfusion of the slice with high glucose concentrations in the presence of $2 \mathrm{mM}$ ATP in the pipette only in a few cells electrical activity could be detected. This meets the unchanged conductance of the cell found under those conditions. Surprisingly, although high glucose was able to induce electrical activity with $5 \mathrm{mM}$ ATP in the pipette, it did not change the conductance of the patched $\beta$-cells. Apparently with a given ATP concentration in the pipette solution glucose is not able to increase ATP levels via metabolism. A possible explanation for the detected electrical activity despite any change in conductance is the contribution of gap junctions since they were reported to spread current between electrical active $\beta$-cells (Eddlestone et al., 1984) For this purpose connexin36-deficient mice which lack gap junctions were investigated. In wild type Cx36 
$(+/+)$ as well as in homozygous connexin36 knock-out mice, application of 5 mM ATP to the interior of the $\beta$-cell was able to lower conductance close to the value measured for gap junctions. Nevertheless, it only induced electrical activity in $\beta$-cells of $\mathrm{Cx} 36(-/-)$. Wild type $\beta$-cells depolarized to a level clearly lower than the threshold potential for electrical activity. Additional superfusion of the slice with tolbutamide or high glucose was necessary to depolarize the membrane potential further to reach threshold potential and enabled the detection of electrical activity. Furthermore, the recorded activity was shown to be injected by the electrical activity of neighboring $\beta$-cells in wild type mice. This suggests gap junctions to have an important regulatory role on electrical activity of $\beta$-cells. It concludes that closing $\mathrm{K}_{\mathrm{ATP}}$ channels in a single $\beta$-cell is not enough to induce insulin secretion as long as coupled neighboring $\beta$-cells are still hyperpolarized. By this mechanism gap junctions render $\beta$-cells in islets of Langerhans to a functional syncytium and couple their response to elevated blood glucose levels. As a result insulin secretion from an islet of Langerhans is adapted to regulate blood glucose levels in an optimized way. Electrical coupling averts insulin secretion of single, highly glucose sensitive $\beta$-cells to basal blood glucose levels. Not until the glucose concentration is high enough to stimulate the majority of coupled cells, insulin secretion from the syncytium is induced. This explains the reported reduced heterogeneity in glucose sensitivity of coupled $\beta$-cells compared to single $\beta$-cells (Bosco and Meda, 1991). Thus, one effect of coupling is to prevent exhaustion of highly sensitive $\beta$-cells. Another and probably more important effect is the constriction of the glucose concentration range that induces insulin secretion and an increase in steepness of the dose response curve. This enables a faster and more precise control of the blood glucose level. Support for this theory comes from 
mathematical modeling (Smolen et al., 1993) and a recent study on the glucose responsiveness of $\beta$-cells in Cx36 (-/-) (Meda, personal communication).

\subsection{Performing the patch-clamp technique in tissue slices}

In the present study the whole-cell patch-clamp technique was used to study channel activity in $\beta$-cells. In this technique gentle suction through the pipette on the prior established patch breaks a hole in the plasma membrane, gaining access to the interior of the cell. The main disadvantage of this technique is the possible loss of cytosolic factors that may be important for intracellular signaling (Penner, 1995). Typically, electrical activity of $\beta$-cells is studied by using the perforated patch-clamp technique to avoid this problem. In this technique membrane perforating substances like amphotericin B are included in the pipette to form channels. These small size channels give low-resistance access to the cell only allowing passage of small ions (Rae et al., 1991). Applying the patch-clamp technique in deeper cell layers of tissue slices requires positive pressure on the patch pipette to increase the success rate (Stuart et al., 1993). This complicates the use of perforated patch-clamp in tissue slices, as it is difficult to control the exact time point for the perforating substance to reach the pipette tip. Still it will be necessary to employ the perforated patch-clamp technique for studies on $\beta$-cells, which are dependent on an intact intracellular environment. However, the application of whole-cell patch-clamp was an adequate method for the topics studied in the present report. Access to the cytosol in whole-cell patch-clamp makes it possible to apply substances with the pipette solution to the interior of the cell and reveal their effects. This was of major interest for the present study as the effect of different intracellular ATP concentrations on the whole-cell conductance of the $\beta$-cell was analyzed. Of major importance for the intracellular 
application of substances through the patch pipette is the velocity of the diffusion process. It turned out that this diffusion process can be used as a fast application to compare sensitivities to certain substances. Excluding ATP from the pipette solution leads to a gradual decrease of intracellular ATP from the basal level to nearly $0 \mathrm{mM}$ ATP. It has to be considered that the diffusion exchange rate between the pipette and the cell is highly dependent on the size of the cell and the resistance of the connection (Pusch and Neher, 1988). Provided that the same conditions are given, a faster $\mathrm{K}_{\mathrm{ATP}}$ channel activation during dialysis stands for a lower sensitivity of the tested cell.

Furthermore, it can be calculated that in conditions like in this study a molecule of 500 $\mathrm{kD}$, like ATP, had an exchange time of about 30 to 60 seconds. This diffusion exchange rate predicts that the cytosolic compensation in the first minute does not differ too much from perforated patch experiments. Experiments on $\beta$-cells of Cx36 (-/-) mice showed the electrical activity to run-down within 60 to 120 seconds (Fig. 5; upper trace). This is probably due to the wash-out of cytosolic factors necessary for $\mathrm{Ca}^{2+}$ channel activity. It shows that representative electrophysiological measurements can be performed during the first 60 seconds using whole-cell mode. Nevertheless, after 60 to 120 seconds washout seems to prevent the maintenance or induction of electrical activity. Recording electrical activity of wild type $\beta$-cells in whole-cell mode after two minutes dialysis is therefore likely to show only activity of neighboring $\beta$-cells. Comparing the size of the spikes during electrical activity in $\mathrm{Cx} 36(+/+)$ and $\mathrm{Cx} 36(-/-)$ supports this assumption. Spikes recorded from $\beta$-cells of $\mathrm{Cx} 36$ (-/-) mice started from the threshold potential of about $-40 \mathrm{mV}$ and peaked at about $-10 \mathrm{mV}$. Membrane potential spikes of Cx36 (+/+) also started at threshold potential, but only had a size of about $15 \mathrm{mV}$. Taking into 
account that the gap junction conductance of $\mathrm{Cx} 36(+/+)$ mice is about $1.5 \mathrm{nS}$, it can be concluded that the current injections from the neighboring cells of $\sim 25 \mathrm{pA}$ are the cause for the recorded spiking.

Additionally to the wash-out of cytosolic components, affecting the exhibition of electrical activity, the application of ATP via the patch pipette clamps the intracellular ATP concentration. Induction of electrical activity in the patched cell by application of elevated glucose levels is therefore not possible, as it is not able increase the given cytosolic ATP concentration.

\subsection{Perspectives for the pancreatic tissue slice preparation}

The tissue slice preparation of murine pancreas serves as a promising model to study various topics on all kinds of tissues occurring in the pancreas. The present study revealed the practicability of the preparation, especially concerning the investigation of insulin secreting $\beta$-cells. Differences in $\beta$-cell properties due to the preparation and the action of structures, discussed for many years, were discovered. In future the employment of pancreatic tissue slices will help to disclose participating mechanisms in $\beta$-cell function, including development and modulation. Furthermore, pancreatic tissue slices provide another possibility to study the processes leading to secretion in neuroendocrine cells. 


\section{Summary}

In the present study a pancreatic tissue slice preparation was established to enable the characterization of insulin secreting $\beta$-cells in close to in vivo conditions. The procedure to obtain pancreatic tissue slices was found to be rapid and easily reproducible. Slices were viable for at least one day and gross morphology was well preserved. Functionality of $\beta$-cells in tissue slices was confirmed by measuring released insulin after application of high glucose concentrations.

The tissue slice preparation enabled the execution of electrophysiological experiments on $\beta$-cells located in deeper layers of the islet of Langerhans. Characterizing $\beta$-cells in tissue slices revealed several different properties compared to preparations used to date. First, the secretion rate acquired by monitoring capacitance in $\beta$-cells of tissue slices was comparable to biochemical measurements of insulin release obtained from perfused pancreas. Experiments on cultured $\beta$-cells and $\beta$-cells in isolated islets of Langerhans failed to show this similarity. Furthermore, in tissue slices $K_{A T P}$ channels in $\beta$-cells showed decreased sensitivity to ATP in comparison to dispersed $\beta$-cells, shifting the regulation of $\mathrm{K}_{\mathrm{ATP}}$ channels by ATP to physiological levels. Additionally, the run-down of $\mathrm{K}_{\mathrm{ATP}}$ channels in $\beta$-cells of tissue slices was shown to be accelerated.

Recording electrical activity in response to stimulating agents from $\beta$-cells in slices showed the characteristic bursting pattern. However, studies on gap junction-deficient mice $(\mathrm{Cx} 36 \mathrm{ko})$ proved electrical activity of $\beta$-cells to vanish due to wash-out after dialysis of the pipette solution. The electrical activity recorded from wild type mice in whole-cell configuration reflected the activity of electrically coupled $\beta$-cells. Furthermore, the presence of gap junctions prevented electrical activity in a single 
stimulated $\beta$-cell, as long as the majority of coupled cells was still in a resting state, contributing to synchronized insulin release from the islet.

The study showed pancreatic tissue slices as a promising, less invasive method to study the function of $\beta$-cells. In this preparation $\beta$-cells were observed to exhibit properties assumed for in vivo conditions. Employment of the pancreatic tissue slice preparation will serve as a suitable system to gain further insight into the complex interactions controlling blood glucose homeostasis. 


\section{References}

Adeghate, E., Ponery, A. S., Pallot, D. J., and Singh, J. (2001). Distribution of vasoactive intestinal polypeptide, neuropeptide- $Y$ and substance $P$ and their effects on insulin secretion from the in vitro pancreas of normal and diabetic rats. Peptides 22, 99107.

Aguilar-Bryan, L., and Bryan, J. (1999). Molecular biology of adenosine triphosphatesensitive potassium channels. Endocr Rev 20, 101-135.

Ahren, B., Ericson, L. E., Lundquist, I., Loren, I., and Sundler, F. (1981). Adrenergic innervation of pancreatic islets and modulation of insulin secretion by the sympatho-adrenal system. Cell Tissue Res 216, 15-30.

Ahren, B., Paquette, T. L., and Taborsky, G. J., Jr. (1986). Effect and mechanism of vagal nerve stimulation on somatostatin secretion in dogs. Am J Physiol 250, E212-217.

Ahren, B., and Taborsky, G. J., Jr. (1986). The mechanism of vagal nerve stimulation of glucagon and insulin secretion in the dog. Endocrinology 118, 1551-1557.

Ahren, B., Veith, R. C., and Taborsky, G. J., Jr. (1987). Sympathetic nerve stimulation versus pancreatic norepinephrine infusion in the dog: 1). Effects on basal release of insulin and glucagon. Endocrinology 121, 323-331.

Ahren, B., and Taborsky, G. J., Jr. (1988). Effects of pancreatic noradrenaline infusion on basal and stimulated islet hormone secretion in the dog. Acta Physiol Scand 132, 143-150.

Ahren, B., Bottcher, G., Kowalyk, S., Dunning, B. E., Sundler, F., and Taborsky, G. J., Jr. (1990a). Galanin is co-localized with noradrenaline and neuropeptide $\mathrm{Y}$ in dog pancreas and celiac ganglion. Cell Tissue Res 261, 49-58.

Ahren, B., Karlsson, S., and Lindskog, S. (1990b). Cholinergic regulation of the endocrine pancreas. In: Progress in Brain Research, Cholinergic Neurotransmission, vol 84, S. Aquilonius, and P. G. Gillberg, eds. (Amsterdam, Elsevier), pp. 209-218.

Ahren, B. (2000). Autonomic regulation of islet hormone secretion--implications for health and disease. Diabetologia 43, 393-410.

Aizawa, T., Kaneko, T., Yamauchi, K., Yajima, H., Nishizawa, T., Yada, T., Matsukawa, H., Nagai, M., Yamada, S., Sato, Y., et al. (2001). Size-related and size-unrelated functional heterogeneity among pancreatic islets. Life Sci 69, 2627-2639. 
Ammala, C., Eliasson, L., Bokvist, K., Larsson, O., Ashcroft, F. M., and Rorsman, P. (1993). Exocytosis elicited by action potentials and voltage-clamp calcium currents in individual mouse pancreatic B-cells. J Physiol 472, 665-688.

Ashcroft, F. M., Harrison, D. E., and Ashcroft, S. J. (1984). Glucose induces closure of single potassium channels in isolated rat pancreatic beta-cells. Nature $312,446-$ 448.

Ashcroft, F. M. (1988). Adenosine 5'-triphosphate-sensitive potassium channels. Annu Rev Neurosci 11, 97-118.

Ashcroft, F. M., and Rorsman, P. (1989). Electrophysiology of the pancreatic beta-cell. Prog Biophys Mol Biol 54, 87-143.

Ashcroft, S. J., Weerasinghe, L. C., and Randle, P. J. (1973). Interrelationship of islet metabolism, adenosine triphosphate content and insulin release. Biochem $\mathrm{J} 132$, 223-231.

Ashcroft, S. J., Bunce, J., Lowry, M., Hansen, S. E., and Hedeskov, C. J. (1978). The effect of sugars on (pro)insulin biosynthesis. Biochem J 174, 517-526.

Ashcroft, S. J. (1980). Glucoreceptor mechanisms and the control of insulin release and biosynthesis. Diabetologia 18, 5-15.

Atwater, I., Ribalet, B., and Rojas, E. (1978). Cyclic changes in potential and resistance of the beta-cell membrane induced by glucose in islets of Langerhans from mouse. J Physiol 278, 117-139.

Barbosa, R. M., Silva, A. M., Tome, A. R., Stamford, J. A., Santos, R. M., and Rosario, L. M. (1996). Real time electrochemical detection of 5-HT/insulin secretion from single pancreatic islets: effect of glucose and $\mathrm{K}+$ depolarization. Biochem Biophys Res Commun 228, 100-104.

Baukrowitz, T., Schulte, U., Oliver, D., Herlitze, S., Krauter, T., Tucker, S. J., Ruppersberg, J. P., and Fakler, B. (1998). PIP2 and PIP as determinants for ATP inhibition of KATP channels. Science 282, 1141-1144.

Bell, G. I., Pictet, R. L., Rutter, W. J., Cordell, B., Tischer, E., and Goodman, H. M. (1980). Sequence of the human insulin gene. Nature 284, 26-32.

Berthoud, H. R., Bereiter, D. A., Trimble, E. R., Siegel, E. G., and Jeanrenaud, B. (1981). Cephalic phase, reflex insulin secretion. Neuroanatomical and physiological characterization. Diabetologia 20 Suppl, 393-401. 
Bloom, S. R., and Edwards, A. V. (1981). Pancreatic endocrine responses to stimulation of the peripheral ends of the vagus nerves in conscious calves. J Physiol 315, 3141.

Bloom, S. R., and Edwards, A. V. (1984). Characteristics of the neuroendocrine responses to stimulation of the splanchnic nerves in bursts in the conscious calf. $\mathrm{J}$ Physiol 346, 533-545.

Bodziony, J., and Schwille, P. O. (1989). In vitro secretion of hormones from the islets of pancreas with acinar atrophy--influence of digestion with collagenase. Exp Clin Endocrinol 94, 338-344.

Bosco, D., and Meda, P. (1991). Actively synthesizing beta-cells secrete preferentially after glucose stimulation. Endocrinology 129, 3157-3166.

Branstrom, R., Leibiger, I. B., Leibiger, B., Corkey, B. E., Berggren, P. O., and Larsson, O. (1998). Long chain coenzyme A esters activate the pore-forming subunit (Kir6. 2) of the ATP-regulated potassium channel. J Biol Chem 273, 31395-31400.

Bratanova-Tochkova, T. K., Cheng, H., Daniel, S., Gunawardana, S., Liu, Y. J., Mulvaney-Musa, J., Schermerhorn, T., Straub, S. G., Yajima, H., and Sharp, G. W. (2002). Triggering and augmentation mechanisms, granule pools, and biphasic insulin secretion. Diabetes 51 Suppl 1, S83-90.

Brunicardi, F. C., Shavelle, D. M., and Andersen, D. K. (1995). Neural regulation of the endocrine pancreas. Int J Pancreatol 18, 177-195.

Bruzzone, R., White, T. W., and Paul, D. L. (1996). Connections with connexins: the molecular basis of direct intercellular signaling. Eur J Biochem 238, 1-27.

Carter, T. D., and Ogden, D. (1994). Acetylcholine-stimulated changes of membrane potential and intracellular $\mathrm{Ca} 2+$ concentration recorded in endothelial cells in situ in the isolated rat aorta. Pflugers Arch 428, 476-484.

Caulfield, M. P., and Birdsall, N. J. (1998). International Union of Pharmacology. XVII. Classification of muscarinic acetylcholine receptors. Pharmacol Rev 50, 279-290.

Cegrell, L. (1968). The occurrence of biogenic monoamines in the mammalian endocrine pancreas. Acta Physiol Scand Suppl 314, 1-60.

Cerasi, E. (1992). Aetiology of type II diabetes. In: Insulin: Molecular Biology to Pathology, F. M. Ashcroft, and S. J. Ashcroft, eds. (Oxford, UK, Oxford University Press), pp. 347-392.

Chiba, Y., Kawai, K., Okuda, Y., Munekata, E., and Yamashita, K. (1985). Effects of substance $\mathrm{P}$ and substance $\mathrm{P}-(6-11)$ on hormone release from isolated perfused 
pancreas: their opposite actions on rat and canine islets. Endocrinology 117, 1996-2000.

Clark, A., Jones, L. C., de Koning, E., Hansen, B. C., and Matthews, D. R. (2001). Decreased insulin secretion in type 2 diabetes: a problem of cellular mass or function? Diabetes 50 Suppl 1, S169-171.

Cook, D. L., and Hales, C. N. (1984). Intracellular ATP directly blocks K+ channels in pancreatic B-cells. Nature 311, 271-273.

Cook, D. L., Satin, L. S., and Hopkins, W. F. (1991). Pancreatic B cells are bursting, but how? Trends Neurosci 14, 411-414.

Coore, H. G., and Randle, P. J. (1964). Regulation of insulin secretion studied with pieces of rabbit pancreas incubated in vitro. Biochem J 93, 66-78.

Coupland, R. E. (1958). The innervation of pan creas of the rat, cat and rabbit as revealed by the cholinesterase technique. J Anat 92, 143-149.

Creutzfeldt, W. (1979). The incretin concept today. Diabetologia 16, 75-85.

De Vos, A., Heimberg, H., Quartier, E., Huypens, P., Bouwens, L., Pipeleers, D., and Schuit, F. (1995). Human and rat beta cells differ in glucose transporter but not in glucokinase gene expression. J Clin Invest 96, 2489-2495.

Dean, P. M., and Matthews, E. K. (1968). Electrical activity in pancreatic islet cells. Nature 219, 389-390.

Dean, P. M., and Matthews, E. K. (1970). Glucose-induced electrical activity in pancreatic islet cells. J Physiol 210, 255-264.

Degano, P., Peiro, E., Miralles, P., Silvestre, R. A., and Marco, J. (1992). Effects of rat pancreatic polypeptide on islet-cell secretion in the perfused rat pancreas. Metabolism 41, 306-309.

Detimary, P., Gilon, P., Nenquin, M., and Henquin, J. C. (1994). Two sites of glucose control of insulin release with distinct dependence on the energy state in pancreatic B-cells. Biochem J 297 ( Pt 3), 455-461.

Dunne, M. J., and Petersen, O. H. (1986). Intracellular ADP activates K+ channels that are inhibited by ATP in an insulin-secreting cell line. FEBS Lett 208, 59-62.

Dunning, B. E., Ahren, B., Veith, R. C., Bottcher, G., Sundler, F., and Taborsky, G. J., Jr. (1986). Galanin: a novel pancreatic neuropeptide. Am J Physiol 251, E127-133. 
Dupre, J., Ross, S. A., Watson, D., and Brown, J. C. (1973). Stimulation of insulin secretion by gastric inhibitory polypeptide in man. J Clin Endocrinol Metab 37, 826-828.

Duttaroy, A., Zimliki, C. L., Gautam, D., Cui, Y., Mears, D., and Wess, J. (2004). Muscarinic Stimulation of Pancreatic Insulin and Glucagon Release Is Abolished in M3 Muscarinic Acetylcholine Receptor-Deficient Mice. Diabetes 53, 17141720 .

Eddlestone, G. T., Goncalves, A., Bangham, J. A., and Rojas, E. (1984). Electrical coupling between cells in islets of Langerhans from mouse. J Membr Biol 77, 114.

Edwards, A. V., and Bloom, S. R. (1994). Pancreatic endocrine responses to substance P and calcitonin gene-related peptide in conscious calves. Am J Physiol 267, E847852.

Ekblad, E., Alm, P., and Sundler, F. (1994). Distribution, origin and projections of nitric oxide synthase-containing neurons in gut and pancreas. Neuroscience 63, 233248.

Elrick, H., Stimmler, L., Hlad, C. J., Jr., and Arai, Y. (1964). Plasma Insulin Response to Oral and Intravenous Glucose Administration. J Clin Endocrinol Metab 24, 10761082.

Esterhuizen, A. C., Spriggs, T. L., and Lever, J. D. (1968). Nature of islet-cell innervation in the cat pancreas. Diabetes 17, 33-36.

Fehmann, H. C., Goke, R., and Goke, B. (1995). Cell and molecular biology of the incretin hormones glucagon-like peptide-I and glucose-dependent insulin releasing polypeptide. Endocr Rev 16, 390-410.

Findlay, I. (1988). Calcium-dependent inactivation of the ATP-sensitive K+ channel of rat ventricular myocytes. Biochim Biophys Acta 943, 297-304.

Flatt, P. (2003). The hormonal and neuronal control of endocrine pancreatic function. In: Textbook of Diabetes, J. C. Pickup, and G. Williams, eds. (Oxford, UK, Blackwell Science Ltd), pp. 11.01-11.21.

Freeman, B. A., and O'Neil, J. J. (1984). Tissue slices in the study of lung metabolism and toxicology. Environ Health Perspect 56, 51-60.

Fridolf, T., Sundler, F., and Ahren, B. (1992). Pituitary adenylate cyclase-activating polypeptide (PACAP): occurrence in rodent pancreas and effects on insulin and glucagon secretion in the mouse. Cell Tissue Res 269, 275-279. 
Fujita, T. (1959). Histological Studies on the Neuro-Insular Complex in the Pancreas of Some Mammals. Zeitschrift Fur Zellforschung Und Mikroskopische Anatomie 50, 94-109.

Furukawa, T., Yamane, T., Terai, T., Katayama, Y., and Hiraoka, M. (1996). Functional linkage of the cardiac ATP-sensitive $\mathrm{K}+$ channel to the actin cytoskeleton. Pflugers Arch 431, 504-512.

Gahwiler, B. H., Capogna, M., Debanne, D., McKinney, R. A., and Thompson, S. M. (1997). Organotypic slice cultures: a technique has come of age. Trends Neurosci 20, 471-477.

Gandolfi, A. J., Wijeweera, J., and Brendel, K. (1996). Use of precision-cut liver slices as an in vitro tool for evaluating liver function. Toxicol Pathol 24, 58-61.

Gembal, M., Gilon, P., and Henquin, J. C. (1992). Evidence that glucose can control insulin release independently from its action on ATP-sensitive $\mathrm{K}+$ channels in mouse B cells. J Clin Invest 89, 1288-1295.

Gembal, M., Detimary, P., Gilon, P., Gao, Z. Y., and Henquin, J. C. (1993). Mechanisms by which glucose can control insulin release independently from its action on adenosine triphosphate-sensitive $\mathrm{K}+$ channels in mouse B cells. J Clin Invest 91, 871-880.

Godfrey, D. A., and Matschinsky, F. M. (1975). Enzymes of the cholinergic system in islets of Langerhans. J Histochem Cytochem 23, 645-651.

Gopel, S., Kanno, T., Barg, S., Galvanovskis, J., and Rorsman, P. (1999). Voltage-gated and resting membrane currents recorded from B-cells in intact mouse pancreatic islets. J Physiol 521 Pt 3, 717-728.

Gopel, S., Zhang, Q., Eliasson, L., Ma, X. S., Galvanovskis, J., Kanno, T., Salehi, A., and Rorsman, P. (2004). Capacitance measurements of exocytosis in mouse pancreatic alpha-, beta- and delta-cells within intact islets of Langerhans. J Physiol 556, 711726.

Gribble, F. M., Proks, P., Corkey, B. E., and Ashcroft, F. M. (1998). Mechanism of cloned ATP-sensitive potassium channel activation by oleoyl-CoA. J Biol Chem 273, 26383-26387.

Grynkiewicz, G., Poenie, M., and Tsien, R. Y. (1985). A new generation of Ca2+ indicators with greatly improved fluorescence properties. J Biol Chem 260, 34403450 .

Guldenagel, M., Ammermuller, J., Feigenspan, A., Teubner, B., Degen, J., Sohl, G., Willecke, K., and Weiler, R. (2001). Visual transmission deficits in mice with 
targeted disruption of the gap junction gene connexin36. J Neurosci 21, 60366044.

Hales, C. N., and Milner, R. D. (1968). The role of sodium and potassium in insulin secretion from rabbit pancreas. J Physiol 194, 725-743.

Hamill, O. P., Marty, A., Neher, E., Sakmann, B., and Sigworth, F. J. (1981). Improved patch-clamp techniques for high-resolution current recording from cells and cellfree membrane patches. Pflugers Arch 391, 85-100.

Havel, P. J., Dunning, B. E., Verchere, C. B., Baskin, D. G., O'Dorisio, T., and Taborsky, G. J., Jr. (1997). Evidence that vasoactive intestinal polypeptide is a parasympathetic neurotransmitter in the endocrine pancreas in dogs. Regul Pept $71,163-170$.

Henquin, J. C. (1978). D-glucose inhibits potassium efflux from pancreatic islet cells. Nature 271, 271-273.

Henquin, J. C., and Meissner, H. P. (1984). Significance of ionic fluxes and changes in membrane potential for stimulus-secretion coupling in pancreatic B-cells. Experientia 40, 1043-1052.

Henquin, J. C., Ravier, M. A., Nenquin, M., Jonas, J. C., and Gilon, P. (2003). Hierarchy of the beta-cell signals controlling insulin secretion. Eur J Clin Invest 33, 742750 .

Hilgemann, D. W., and Ball, R. (1996). Regulation of cardiac Na+,Ca2+ exchange and KATP potassium channels by PIP2. Science 273, 956-959.

Hirrlinger, J., Braun, C., Quintela-Schneider, M., Pawlowski, P. G., Hussmann, F., Hülsmann, S., and Kirchhoff, F. (2004). Double transgenic TgN (hGFAP-EGFP) (Thy 1.2-HcRed)-mice as a model system to study neuron-glia interaction. FENS Forum Abstracts 2, A039.035.

Holst, J. J., Gronholt, R., Schaffalitzky de Muckadell, O. B., and Fahrenkrug, J. (1981). Nervous control of pancreatic endocrine secretion in pigs. II. The effect of pharmacological blocking agents on the response to vagal stimulation. Acta Physiol Scand 111, 9-14.

Holst, J. J., Jensen, S. L., Knuhtsen, S., and Nielsen, O. V. (1983). Autonomic nervous control of pancreatic somatostatin secretion. Am J Physiol 245, E542-548.

Iversen, J. (1973). Effect of acetyl choline on the secretion of glucagon and insulin from the isolated, perfused canine pancreas. Diabetes 22, 381-387. 
Jansson, L., and Hellerstrom, C. (1983). Stimulation by glucose of the blood flow to the pancreatic islets of the rat. Diabetologia 25, 45-50.

Jarhult, J., and Holst, J. J. (1978). Reflex adrenergic control of endocrine pancreas evoked by unloading of carotid baroreceptors in cats. Acta Physiol Scand 104, 188-202.

Jarhult, J., and Holst, J. (1979). The role of the adrenergic innervation to the pancreatic islets in the control of insulin release during exercise in man. Pflugers Arch 383, 41-45.

Johnson, J. H., Newgard, C. B., Milburn, J. L., Lodish, H. F., and Thorens, B. (1990). The high $\mathrm{Km}$ glucose transporter of islets of Langerhans is functionally similar to the low affinity transporter of liver and has an identical primary sequence. J Biol Chem 265, 6548-6551.

Kanno, T., Ma, X., Barg, S., Eliasson, L., Galvanovskis, J., Gopel, S., Larsson, M., Renstrom, E., and Rorsman, P. (2004). Large dense-core vesicle exocytosis in pancreatic beta-cells monitored by capacitance measurements. Methods 33, 302311.

Karlsson, S., Sundler, F., and Ahren, B. (1992). Neonatal capsaicin-treatment in mice: effects on pancreatic peptidergic nerves and 2-deoxy-D-glucose-induced insulin and glucagon secretion. J Auton Nerv Syst 39, 51-59.

Karlsson, S., and Ahren, B. (1993). Muscarinic Receptor Subtypes in CarbacholStimulated Insulin and Glucagon-Secretion in the Mouse. Journal of Autonomic Pharmacology 13, 439-446.

Khan, F. A., Goforth, P. B., Zhang, M., and Satin, L. S. (2001). Insulin activates ATPsensitive $\mathrm{K}(+)$ channels in pancreatic beta-cells through a phosphatidylinositol 3kinase-dependent pathway. Diabetes 50, 2192-2198.

Kirchgessner, A. L., and Gershon, M. D. (1990). Innervation of the pancreas by neurons in the gut. J Neurosci 10, 1626-1642.

Knuhtsen, S., Holst, J. J., Baldissera, F. G., Skak-Nielsen, T., Poulsen, S. S., Jensen, S. L., and Nielsen, O. V. (1987). Gastrin-releasing peptide in the porcine pancreas. Gastroenterology 92, 1153-1158.

Kohen, E., Kohen, C., Thorell, B., Mintz, D. H., and Rabinovitch, A. (1979). Intercellular communication in pancreatic islet monolayer cultures: a microfluorometric study. Science 204, 862-865.

Kreymann, B., Williams, G., Ghatei, M. A., and Bloom, S. R. (1987). Glucagon-like peptide-1 7-36: a physiological incretin in man. Lancet 2, 1300-1304. 
Kukuljan, M., Goncalves, A. A., and Atwater, I. (1991). Charybdotoxin-sensitive K(Ca) channel is not involved in glucose-induced electrical activity in pancreatic betacells. J Membr Biol 119, 187-195.

Kurose, T., Seino, Y., Nishi, S., Tsuji, K., Taminato, T., Tsuda, K., and Imura, H. (1990). Mechanism of sympathetic neural regulation of insulin, somatostatin, and glucagon secretion. Am J Physiol 258, E220-227.

Lacy, P. E., and Kostianovsky, M. (1967). Method for the isolation of intact islets of Langerhans from the rat pancreas. Diabetes 16, 35-39.

Larsson, O., Kindmark, H., Brandstrom, R., Fredholm, B., and Berggren, P. O. (1996). Oscillations in KATP channel activity promote oscillations in cytoplasmic free Ca2+ concentration in the pancreatic beta cell. Proc Natl Acad Sci U S A 93, 5161-5165.

Lefebvre, P. J. (1995). Glucagon and its family revisited. Diabetes Care 18, 715-730.

Lernmark, A. (1974). The preparation of, and studies on, free cell suspensions from mouse pancreatic islets. Diabetologia 10, 431-438.

Lifson, N., Lassa, C. V., and Dixit, P. K. (1985). Relation between blood flow and morphology in islet organ of rat pancreas. Am J Physiol 249, E43-48.

Lundquist, I., Sundler, F., Ahren, B., Alumets, J., and Hakanson, R. (1979). Somatostatin, pancreatic polypeptide, substance $\mathrm{P}$, and neurotensin: cellular distribution and effects on stimulated insulin secretion in the mouse. Endocrinology 104, 832-838.

Lynch, G., and Schubert, P. (1980). The use of in vitro brain slices for multidisciplinary studies of synaptic function. Annu Rev Neurosci 3, 1-22.

Ma, Y. H., Wang, J., Rodd, G. G., Bolaffi, J. L., and Grodsky, G. M. (1995). Differences in insulin secretion between the rat and mouse: role of cAMP. Eur J Endocrinol $132,370-376$.

MacDonald, P. E., Ha, X. F., Wang, J., Smukler, S. R., Sun, A. M., Gaisano, H. Y., Salapatek, A. M., Backx, P. H., and Wheeler, M. B. (2001). Members of the Kv1 and $\mathrm{Kv} 2$ voltage-dependent $\mathrm{K}(+)$ channel families regulate insulin secretion. Mol Endocrinol 15, 1423-1435.

MacDonald, P. E., Sewing, S., Wang, J., Joseph, J. W., Smukler, S. R., Sakellaropoulos, G., Saleh, M. C., Chan, C. B., Tsushima, R. G., Salapatek, A. M., and Wheeler, M. B. (2002). Inhibition of Kv2.1 voltage-dependent $\mathrm{K}+$ channels in pancreatic beta-cells enhances glucose-dependent insulin secretion. J Biol Chem 277, 4493844945. 
Matsuyama, T., Komatsu, R., Namba, M., Watanabe, N., Itoh, H., and Tarui, S. (1988). Glucagon-like peptide-1 (7-36 amide): a potent glucagonostatic and insulinotropic hormone. Diabetes Res Clin Pract 5, 281-284.

Matthews, D. R. (1991). Physiological implications of pulsatile hormone secretion. Ann N Y Acad Sci 618, 28-37.

Meda, P., Bosco, D., Chanson, M., Giordano, E., Vallar, L., Wollheim, C., and Orci, L. (1990). Rapid and reversible secretion changes during uncoupling of rat insulinproducing cells. J Clin Invest 86, 759-768.

Meneghel-Rozzo, T., Rozzo, A., Poppi, L., and Rupnik, M. (2004). In vivo and in vitro development of mouse pancreatic beta-cells in organotypic slices. Cell Tissue Res 316, 295-303.

Michaels, R. L., and Sheridan, J. D. (1981). Islets of Langerhans: dye coupling among immunocytochemically distinct cell types. Science $214,801-803$.

Misler, S., Falke, L. C., Gillis, K., and McDaniel, M. L. (1986). A metabolite-regulated potassium channel in rat pancreatic B cells. Proc Natl Acad Sci U S A 83, 71197123.

Moens, K., Berger, V., Ahn, J. M., Van Schravendijk, C., Hruby, V. J., Pipeleers, D., and Schuit, F. (2002). Assessment of the role of interstitial glucagon in the acute glucose secretory responsiveness of in situ pancreatic beta-cells. Diabetes 51, 669-675.

Mojsov, S., Heinrich, G., Wilson, I. B., Ravazzola, M., Orci, L., and Habener, J. F. (1986). Preproglucagon gene expression in pancreas and intestine diversifies at the level of post-translational processing. J Biol Chem 261, 11880-11889.

Moltz, J. H., and McDonald, J. K. (1985). Neuropeptide Y: direct and indirect action on insulin secretion in the rat. Peptides $6,1155-1159$.

Mortensen, K., Petersen, L. L., and Orskov, C. (2000). Colocalization of GLP-1 and GIP in human and porcine intestine. Ann N Y Acad Sci 921, 469-472.

Nadal, A., Quesada, I., and Soria, B. (1999). Homologous and heterologous asynchronicity between identified alpha-, beta- and delta-cells within intact islets of Langerhans in the mouse. J Physiol 517 ( Pt 1), 85-93.

Nauck, M., Stockmann, F., Ebert, R., and Creutzfeldt, W. (1986a). Reduced incretin effect in type 2 (non-insulin-dependent) diabetes. Diabetologia 29, 46-52. 
Nauck, M. A., Homberger, E., Siegel, E. G., Allen, R. C., Eaton, R. P., Ebert, R., and Creutzfeldt, W. (1986b). Incretin effects of increasing glucose loads in man calculated from venous insulin and C-peptide responses. J Clin Endocrinol Metab 63, 492-498.

Neher, E., and Marty, A. (1982). Discrete changes of cell membrane capacitance observed under conditions of enhanced secretion in bovine adrenal chromaffin cells. Proc Natl Acad Sci U S A 79, 6712-6716.

Nesher, R., and Cerasi, E. (2002). Modeling phasic insulin release: immediate and timedependent effects of glucose. Diabetes 51 Suppl 1, S53-59.

Niki, I., Ashcroft, F. M., and Ashcroft, S. J. (1989). The dependence on intracellular ATP concentration of ATP-sensitive K-channels and of Na,K-ATPase in intact HITT15 beta-cells. FEBS Lett 257, 361-364.

Noma, A. (1983). ATP-regulated K+ channels in cardiac muscle. Nature 305, 147-148.

Norfleet, W. T., Pagliara, A. S., Haymond, M. W., and Matschinsky, F. (1975). Comparison of alpha- and beta-cell secretory responses in islets isolated with collagenase and in the isolated perfused pancreas of rats. Diabetes 24, 961-970.

Ohno-Shosaku, T., Zunkler, B. J., and Trube, G. (1987). Dual effects of ATP on K+ currents of mouse pancreatic beta-cells. Pflugers Arch 408, 133-138.

Orci, L., Perrelet, A., Ravazzola, M., Malaisse-Lagae, F., and Renold, A. E. (1973a). A specialized membrane junction between nerve endings and B-cells in islets of Langerhans. Eur J Clin Invest 3, 443-445.

Orci, L., Unger, R. H., and Renold, A. E. (1973b). Structural coupling between pancreatic islet cells. Experientia 29, 1015-1018.

Orci, L., Malaisse-Lagae, F., Ravazzola, M., Rouiller, D., Renold, A. E., Perrelet, A., and Unger, R. (1975). A morphological basis for intercellular communication between alpha- and beta-cells in the endocrine pancreas. J Clin Invest 56, 1066-1070.

Orci, L., Ravazzola, M., Amherdt, M., Madsen, O., Perrelet, A., Vassalli, J. D., and Anderson, R. G. (1986). Conversion of proinsulin to insulin occurs coordinately with acidification of maturing secretory vesicles. J Cell Biol 103, 2273-2281.

Panten, U., Schwanstecher, M., Wallasch, A., and Lenzen, S. (1988). Glucose both inhibits and stimulates insulin secretion from isolated pancreatic islets exposed to maximally effective concentrations of sulfonylureas. Naunyn Schmiedebergs Arch Pharmacol 338, 459-462. 
Parrish, A. R., Gandolfi, A. J., and Brendel, K. (1995). Precision-cut tissue slices: applications in pharmacology and toxicology. Life Sci 57, 1887-1901.

Penner, R. (1995). A Practical Guide toPatch Clamping. In: Single-Channel Recording, Second Edition, B. Sakmann, and E. Neher, eds. (New York, Plenum Press), pp. 3-30.

Perez-Armendariz, M., Roy, C., Spray, D. C., and Bennett, M. V. (1991). Biophysical properties of gap junctions between freshly dispersed pairs of mouse pancreatic beta cells. Biophys J 59, 76-92.

Pettersson, M., Ahren, B., Bottcher, G., and Sundler, F. (1986). Calcitonin gene-related peptide: occurrence in pancreatic islets in the mouse and the rat and inhibition of insulin secretion in the mouse. Endocrinology 119, 865-869.

Pipeleers, D., in't Veld, P. I., Maes, E., and Van De Winkel, M. (1982). Glucose-induced insulin release depends on functional cooperation between islet cells. Proc Natl Acad Sci U S A 79, 7322-7325.

Pipeleers, D. G., Schuit, F. C., in't Veld, P. A., Maes, E., Hooghe-Peters, E. L., Van de Winkel, M., and Gepts, W. (1985). Interplay of nutrients and hormones in the regulation of insulin release. Endocrinology 117, 824-833.

Porte, D., Jr., and Williams, R. H. (1966). Inhibition of insulin release by norepinephrine in man. Science 152, 1248-1250.

Pusch, M., and Neher, E. (1988). Rates of diffusional exchange between small cells and a measuring patch pipette. Pflugers Arch 411, 204-211.

Quesada, I., Nadal, A., and Soria, B. (1999). Different effects of tolbutamide and diazoxide in alpha, beta-, and delta-cells within intact islets of Langerhans. Diabetes 48, 2390-2397.

Quesada, I., Fuentes, E., Andreu, E., Meda, P., Nadal, A., and Soria, B. (2003). On-line analysis of gap junctions reveals more efficient electrical than dye coupling between islet cells. Am J Physiol Endocrinol Metab 284, E980-987.

Rae, J., Cooper, K., Gates, P., and Watsky, M. (1991). Low access resistance perforated patch recordings using amphotericin B. J Neurosci Methods 37, 15-26.

Rahier, J. (1988). The diabetic pancreas: a pathologist's view. In: The Pathology of the endocrine Pancreas in Diabetes, P. J. Lefèbvre, and D. G. Pipeleers, eds. (Berlin, Springer), pp. 17-40. 
Rehfeld, J. F., Larsson, L. I., Goltermann, N. R., Schwartz, T. W., Holst, J. J., Jensen, S. L., and Morley, J. S. (1980). Neural regulation of pancreatic hormone secretion by the C-terminal tetrapeptide of CCK. Nature 284, 33-38.

Ribalet, B., John, S. A., and Weiss, J. N. (2000). Regulation of cloned ATP-sensitive K channels by phosphorylation, MgADP, and phosphatidylinositol bisphosphate (PIP(2)): a study of channel rundown and reactivation. J Gen Physiol 116, 391410.

Rorsman, P., and Trube, G. (1986). Calcium and delayed potassium currents in mouse pancreatic beta-cells under voltage-clamp conditions. J Physiol 374, 531-550.

Ruegg, C. E. (1994). Preparation of precision-cut renal slices and renal proximal tubular fragments for evaluating segment-specific nephrotoxicity. J Pharmacol Toxicol Methods 31, 125-133.

Salvalaggio, P. R., Deng, S., Ariyan, C. E., Millet, I., Zawalich, W. S., Basadonna, G. P., and Rothstein, D. M. (2002). Islet filtration: a simple and rapid new purification procedure that avoids ficoll and improves islet mass and function. Transplantation $74,877-879$.

Santos, R. M., Rosario, L. M., Nadal, A., Garcia-Sancho, J., Soria, B., and Valdeolmillos, M. (1991). Widespread synchronous [Ca2+]i oscillations due to bursting electrical activity in single pancreatic islets. Pflugers Arch 418, 417-422.

Satin, L. S. (2000). Localized calcium influx in pancreatic beta-cells: its significance for $\mathrm{Ca} 2+-d e p e n d e n t$ insulin secretion from the islets of Langerhans. Endocrine 13, 251-262.

Schulze, D., Rapedius, M., Krauter, T., and Baukrowitz, T. (2003). Long-chain acyl-CoA esters and phosphatidylinositol phosphates modulate ATP inhibition of KATP channels by the same mechanism. J Physiol 552, 357-367.

Schwanstecher, C., Dickel, C., Ebers, I., Lins, S., Zunkler, B. J., and Panten, U. (1992). Diazoxide-sensitivity of the adenosine 5'-triphosphate-dependent $\mathrm{K}+$ channel in mouse pancreatic beta-cells. Br J Pharmacol 107, 87-94.

Sehlin, J., and Taljedal, I. B. (1975). Glucose-induced decrease in Rb+ permeability in pancreatic beta cells. Nature 253, 635-636.

Serre-Beinier, V., Le Gurun, S., Belluardo, N., Trovato-Salinaro, A., Charollais, A., Haefliger, J. A., Condorelli, D. F., and Meda, P. (2000). Cx36 preferentially connects beta-cells within pancreatic islets. Diabetes 49, 727-734.

Sharp, G. W. (1996). Mechanisms of inhibition of insulin release. Am J Physiol 271, C1781-1799. 
Shyng, S., Ferrigni, T., and Nichols, C. G. (1997). Regulation of KATP channel activity by diazoxide and MgADP. Distinct functions of the two nucleotide binding folds of the sulfonylurea receptor. J Gen Physiol 110, 643-654.

Shyng, S. L., and Nichols, C. G. (1998). Membrane phospholipid control of nucleotide sensitivity of KATP channels. Science 282, 1138-1141.

Skibinski, G., and James, K. (1997). The use of tissue slices in immunological investigations. Arch Immunol Ther Exp (Warsz) 45, 411-417.

Smith, P. A., Bokvist, K., Arkhammar, P., Berggren, P. O., and Rorsman, P. (1990). Delayed rectifying and calcium-activated $\mathrm{K}+$ channels and their significance for action potential repolarization in mouse pancreatic beta-cells. J Gen Physiol 95, 1041-1059.

Smolen, P., Rinzel, J., and Sherman, A. (1993). Why pancreatic islets burst but single beta cells do not. The heterogeneity hypothesis. Biophys J 64, 1668-1680.

Sosa-Pineda, B., Chowdhury, K., Torres, M., Oliver, G., and Gruss, P. (1997). The Pax4 gene is essential for differentiation of insulin-producing beta cells in the mammalian pancreas. Nature 386, 399-402.

Srinivas, M., Rozental, R., Kojima, T., Dermietzel, R., Mehler, M., Condorelli, D. F., Kessler, J. A., and Spray, D. C. (1999). Functional properties of channels formed by the neuronal gap junction protein connexin36. J Neurosci 19, 9848-9855.

Stagner, J. I., and Samols, E. (1985). Role of intrapancreatic ganglia in regulation of periodic insular secretions. Am J Physiol 248, E522-530.

Stagner, J. I., Samols, E., and Bonner-Weir, S. (1988). beta----alpha----delta pancreatic islet cellular perfusion in dogs. Diabetes 37, 1715-1721.

Stagner, J. I., and Samols, E. (1992). The vascular order of islet cellular perfusion in the human pancreas. Diabetes 41, 93-97.

Stagner, J. I., Samols, E., Koerker, D. J., and Goodner, C. J. (1992). Perfusion with antiinsulin gamma globulin indicates a B to A to D cellular perfusion sequence in the pancreas of the rhesus monkey, Macaca mulatta. Pancreas 7, 26-29.

Steiner, D., Kemmler, W., Clark, A., Oyer, P., and Rubenstein, A. (1972). The biosynthesis of insulin. In: Handbook of Physiology, Section 7, Vol. 1, D. Steiner, and N. Freinkel, eds. (American Physiological Society), pp. 175-198. 
Sternini, C., and Brecha, N. (1986). Immunocytochemical identification of islet cells and nerve fibers containing calcitonin gene-related peptide-like immunoreactivity in the rat pancreas. Gastroenterology 90, 1155-1163.

St-Onge, L., Sosa-Pineda, B., Chowdhury, K., Mansouri, A., and Gruss, P. (1997). Pax6 is required for differentiation of glucagon-producing alpha-cells in mouse pancreas. Nature 387, 406-409.

Strowski, M. Z., Kohler, M., Chen, H. Y., Trumbauer, M. E., Li, Z., Szalkowski, D., Gopal-Truter, S., Fisher, J. K., Schaeffer, J. M., Blake, A. D., et al. (2003). Somatostatin receptor subtype 5 regulates insulin secretion and glucose homeostasis. Mol Endocrinol 17, 93-106.

Stuart, G. J., Dodt, H. U., and Sakmann, B. (1993). Patch-clamp recordings from the soma and dendrites of neurons in brain slices using infrared video microscopy. Pflugers Arch 423, 511-518.

Sturgess, N. C., Ashford, M. L., Cook, D. L., and Hales, C. N. (1985). The sulphonylurea receptor may be an ATP-sensitive potassium channel. Lancet 2, 474-475.

Sundler, F., and Boucher, G. (1991). Islet innervation with special reference to neuropeptides. In: The Endocrine Pancreas., E. Samols, ed. (New York, Raven Press), pp. 29-53.

Sussman, K. E., Vaughan, G. D., and Timmer, R. F. (1966). An in vitro method for studying insulin secretion in the perfused isolated rat pancreas. Metabolism 15, 466-476.

Taguchi, N., Aizawa, T., Sato, Y., Ishihara, F., and Hashizume, K. (1995). Mechanism of glucose-induced biphasic insulin release: physiological role of adenosine triphosphate-sensitive $\mathrm{K}+$ channel-independent glucose action. Endocrinology 136, 3942-3948.

Taraskevich, P. S., and Douglas, W. W. (1977). Action potentials occur in cells of the normal anterior pituitary gland and are stimulated by the hypophysiotropic peptide thyrotropin-releasing hormone. Proc Natl Acad Sci U S A 74, 4064-4067.

Trimble, E. R., Halban, P. A., Wollheim, C. B., and Renold, A. E. (1982). Functional differences between rat islets of ventral and dorsal pancreatic origin. J Clin Invest 69, 405-413.

Tucker, S. J., Gribble, F. M., Zhao, C., Trapp, S., and Ashcroft, F. M. (1997). Truncation of Kir6.2 produces ATP-sensitive K+ channels in the absence of the sulphonylurea receptor. Nature 387, 179-183. 
Van Schaftingen, E. (1994). Short-term regulation of glucokinase. Diabetologia 37 Suppl 2, S43-47.

Weir, G. C., Leahy, J. L., Barras, E., and Braunstein, L. P. (1986). Characteristics of insulin and glucagon release from the perfused pancreas, intact isolated islets, and dispersed islet cells. Horm Res 24, 62-72.

Weir, G. C., and Bonner-Weir, S. (1990). Islets of Langerhans: the puzzle of intraislet interactions and their relevance to diabetes. J Clin Invest 85, 983-987.

Willecke, K., Eiberger, J., Degen, J., Eckardt, D., Romualdi, A., Guldenagel, M., Deutsch, U., and Sohl, G. (2002). Structural and functional diversity of connexin genes in the mouse and human genome. Biol Chem 383, 725-737.

Wollheim, C. B., and Sharp, G. W. (1981). Regulation of insulin release by calcium. Physiol Rev 61, 914-973.

Xie, L. H., Takano, M., Kakei, M., Okamura, M., and Noma, A. (1999). Wortmannin, an inhibitor of phosphatidylinositol kinases, blocks the MgATP-dependent recovery of Kir6.2/SUR2A channels. J Physiol 514 ( Pt 3), 655-665.

Yamaguchi, A., Chiba, T., Morishita, T., Nakamura, A., Inui, T., Yamatani, T., Kadowaki, S., Chihara, K., Fukase, M., and Fujita, T. (1990). Calcitonin generelated peptide and induction of hyperglycemia in conscious rats in vivo. Diabetes $39,168-174$.

Zhang, M., Goforth, P., Bertram, R., Sherman, A., and Satin, L. (2003). The Ca2+ dynamics of isolated mouse beta-cells and islets: implications for mathematical models. Biophys J 84, 2852-2870. 


\section{Curriculum Vitae}

Personal data:

School education:

University education:

Research activity :

May 2001-

Sept 2004

Stephan

Speier

26.03.1973
Köln, Germany

1977 - $80 \quad$ Primary School Ellon, Scotland

1980 - $81 \quad$ Grundschule Herlikofen, Germany

1981 - 84 Grundschule Mögglingen, Germany

1984 - 92 Hans Baldung Gymnasium, Schwäbisch

Gmünd, Germany

June 1992 Allgemeine Hochschulreife (Abitur)

May 2000 Diploma of Human Biology

PhD Thesis

Neuroendocrinology Group

European Neuroscience Institute (ENI)

Göttingen, Germany 


\section{Publication list}

S. Speier and M. Rupnik (2003). A novel approach to in situ characterization of pancreatic $\beta$-cells. Pflügers Arch., 446 (5): 553-8.

S. Speier, S.-B. Yang, T. Rose and M. Rupnik (2004). $K_{A T P}$ channels in $\beta$-cells in pancreatic slices are directly modulated by millimolar ATP. Submitted. 